\title{
Petrography, Mineralogy, and Geochemistry of Greenish- and Reddish-Gray Siltstones Straddling the Vertebrate-Defined Permian-Triassic Boundary in South Africa
}

Jiawen Li Colby College

Follow this and additional works at: https://digitalcommons.colby.edu/honorstheses

Part of the Geology Commons

Colby College theses are protected by copyright. They may be viewed or downloaded from this site for the purposes of research and scholarship. Reproduction or distribution for commercial purposes is prohibited without written permission of the author.

\section{Recommended Citation}

$\mathrm{Li}$, Jiawen, "Petrography, Mineralogy, and Geochemistry of Greenish- and Reddish-Gray Siltstones Straddling the Vertebrate-Defined Permian-Triassic Boundary in South Africa" (2016). Honors Theses. Paper 814.

https://digitalcommons.colby.edu/honorstheses/814

This Honors Thesis (Open Access) is brought to you for free and open access by the Student Research at Digital Commons @ Colby. It has been accepted for inclusion in Honors Theses by an authorized administrator of Digital Commons@ Colby. 
PETROGRAPHY, MINERALOGY, AND GEOCHEMISTRY OF GREENISH- AND REDDISH-GRAY SILTSTONES STRADDLING THE VERTEBRATE-DEFINED PERMIAN-TRIASSIC BOUNDARY IN SOUTH AFRICA

\author{
Jiawen $\mathrm{Li}$ '16
}

\begin{abstract}
A Thesis
Submitted to the Faculty of the Geology Department of Colby College in Fulfillment of the Requirements for Honors in Geology
\end{abstract}

Waterville, Maine

May, 2016 
PETROGRAPHY, MINERALOGY, AND GEOCHEMISTRY OF GREENISH- AND REDDISH-GRAY SILTSTONES STRADDLING THE VERTEBRATE-DEFINED PERMIAN-TRIASSIC BOUNDARY IN SOUTH AFRICA

Except where the reference is made to the work of others, the work described in this thesis is my own or was done in collaboration with my advisory committee.

Jiawen $\mathrm{Li}$ ' 16

Certificate of Approval:
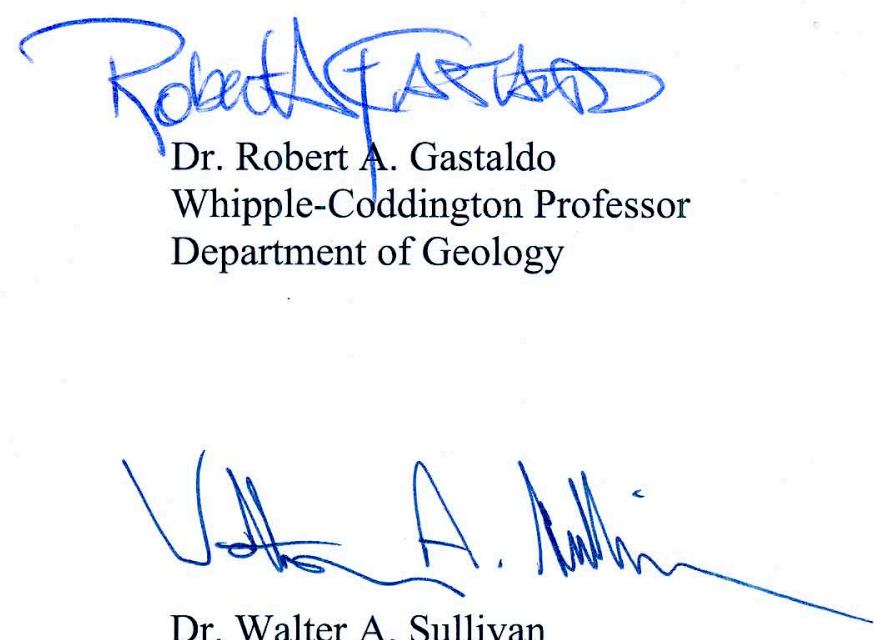

Dr. Walter A. Sullivan Associate Professor and Chair Department of Geology

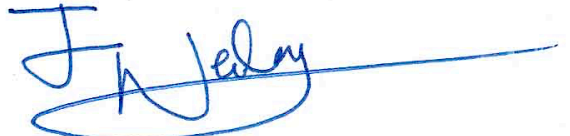

Dr. Johann Neveling Chief Scientist Council for Geoscience Pretoria, South Africa 


\section{ABSTRACT}

The Permian-Triassic Mass Extinction (PTME) is considered the largest in Earth's history, yet the terrestrial response is not well understood. The Karoo Basin, South Africa, hosts abundant exposures of terrestrial deposits that span the PermianTriassic Boundary (PTB). The terrestrial PTB is defined by a turnover in vertebrate assemblage zones and has been associated with a transition from greenish-gray to reddish-gray siltstone. The current PTME model states that the siltstone color change is a reflection of aridification and eolian deposition, which is believed to represent rapid climate change directly linked with the event. Greenish- and reddish-gray siltstones were collected from below, at, and above the vertebrate-defined PTB at Old Lootsberg Pass, Eastern Cape Province, and Bethulie, Free State Province, to test this hypothesis.

Samples are examined petrographically, mineralogically, and geochemically. The presence of primary structures attributed to fluvial processes indicates in-channel, fluvial origin of most samples. Greenish- and reddish-gray siltstones are chemically indistinguishable for most major elements, except for $\mathrm{Na}$, Ti, and Mn. Mössbauer spectroscopy reveals that the reddish-gray color is likely due to the presence of finelydispersed hematite, not a lower $\mathrm{Fe}^{2+} / \mathrm{Fe}^{3+}$ ratio. Hematite primarily occurs as coatings on illite and chlorite. Titanite, rutile, and ilmenite are also found in the reddish-gray siltstones. CIA-K values indicate that these rocks represent deposits in environments with a constantly high water table. Combined, the results indicate that the reddish-gray coloration is secondary to greenish-gray color, and is a product of diagenetic hematite formation under saturated-sediment conditions, likely due to interaction with water in the environments. 


\section{ACKNOWLEDGEMENTS}

I would like to thank the following people whose help made this project possible.

Dr. Darby Dyar and Dr. Elizabeth Sklute, Mount Holyoke College, are acknowledged for providing Mössbauer spectroscopic data. I am grateful to Dr. Martin Yates, the University of Maine-Orono, who offered me the opportunity and instruction for SEM imaging technique. I am also grateful to Dr. Neil Tabor, Dr. Lauren Michel, and Mr. Roy Beavers, Southern Methodist University, who instructed me on obtaining clay mineralogy using XRD. I would like to thank Dr. Bruce Rueger who provided me the equipment and instruction for clay slide preparation. Dr. Whitney King is acknowledged for advice on chemistry-related issues. Thanks to Dr. Catherine Bevier, who allowed me to use the centrifuge in her laboratory. I would also like to thank Alyson Churchill ' 17 and Oriana Battifarano '17, who collected the crucial samples from Bethulie's vertebrate-defined PTB interval. I appreciate the help and company from Takuto Sasajima ' 16 and Kathleen Lipshultz '16, who made the 2015 January field season in South Africa one of my best memories.

I would like to extend my special thanks to my committee members. Dr. Robert Gastaldo provided me guidance throughout the entire project and critical-thinking skills that are indispensable for a career in the natural sciences. Dr. Johann Neveling helped me greatly with sample collection, preparation for the GSA poster presentation, and this thesis. Dr. Walter Sullivan gave me useful advice on writing this thesis.

Support for fieldwork and laboratory analyses was provided by Department of Geology Endowment funds, Office of the Dean of Faculty, Presidential Scholars Opportunity Grant, and NSF funding to RAG (NSF EAR 011-1123570). 


\section{TABLE OF CONTENTS}

Abstract - i

Acknowledgements - ii

1. Introduction -1

2. Geologic Setting -4

3. Previous Work -6

4. Hypotheses -10

5. Methods -11

- 5.1 Sample Collection - 12

- 5.2 Physical Characteristics - 13

- 5.3 Geochemical and Mineralogical Analyses - 14

- 5.4 SEM Imaging of Thin Sections - 20

- 5.5 Data Analyses - 21

6. Results -22

- 6.1 Lithologic Characteristics -22

- 6.2 Elemental Composition - 25

- 6.3 Clay Mineralogy - 26

- $\quad 6.4 \mathrm{Fe}^{2+}$ and $\mathrm{Fe}^{3+}-27$

- $\quad$ 6.5 SEM Imaging - 27

7. Discussion - 29

- 7.1 Variations in Color - 29

- 7.2 Variations in Depositional Environments - 30

- 7.3 Geochemistry and Mineralogy of Samples - 32

- 7.4 Mechanisms for Coloration - 44

8. Summary -54

References -59

Figures -63

Tables -87

Appendices - 104 


\section{INTRODUCTION}

The Permian-Triassic Mass Extinction (PTME) is considered the most catastrophic event in Earth's history. The crisis currently is dated to between $251.941 \pm$ 0.037 and $251.880 \pm 0.031 \mathrm{Ma}$ in the marine realm (Burgess et al., 2014). The record in marine rocks yields fossils, geochronometric ages, and stable-isotopic trends that enable a comprehensive understanding of the causes of, and processes affecting, the PTME in the latest Paleozoic oceans (Payne and Clapham, 2012). In contrast, the latest Permian terrestrial rock record does not necessarily provide the same time resolution. This is because terrestrial deposits are both incomplete, due to long periods of erosion, and modified by climatic and environmental conditions after deposition (DiMichele and Gastaldo, 2008; Gastaldo and Demko, 2011). In addition, these rocks rarely outcrop, which makes the study of the terrestrial PTME more difficult. Among the known places in the world where the terrestrial record of this event is exposed, the Karoo Basin, South Africa, is the most accessible and reported to host the most complete stratigraphic record (Smith, 1995; Ward et al., 2005; Smith and Botha-Brink, 2014; Viglietti et al., 2016; Fig. $1)$.

The vertebrate biostratigraphy of the Karoo Basin, in conjunction with chemostratigraphy and magnetostratigraphy, has been widely used to document the terrestrial response to the PTME (De Kock and Kirschvink, 2004; Ward et al., 2005; Smith and Botha-Brink, 2014; Rey et al., 2016). This is the result of a reported absence of datable volcanic deposits near the vertebrate-defined boundary (Erwin, 2006; Ward et al. 2005). The terrestrial Permian-Triassic Boundary (PTB) has been associated with the replacement of the Dicynodon Assemblage Zone (AZ), recently renamed the 
Daptocephalus AZ (Viglietti et al., 2016), by the Lystrosaurus AZ, and interpreted to be coeval with the marine extinction event (Ward et al., 2005; Smith and Botha-Brink, 2014; Fig. 1). Various problems have been recognized with this biostratigraphy, such as the occurrence of Lystrosaurus taxa in Dicynodon AZ strata (Viglietti et al., 2016). Recently, Gastaldo et al. (2015) reported the first high-precision U-Pb ID-TIMS age from this part of the Karoo Supergroup, which suggests that the turnover occurred in the Early Changhsingian rather than the latest Changhsingian. Their age assignment for the biozone turnover is older than the marine extinction event, and they reasoned that the expression of the terrestrial PTB should be stratigraphically higher and not correlated with the vertebrate turnover as currently recognized. Nonetheless, the vertebrate-defined PTB still is widely recognized and continues to be used in published literature (e.g., Smith and Botha-Brink, 2014; Rey et al., 2015; Viglietti et al., 2016).

The rock succession straddling the reported PTB mainly consists of siltstone with subordinate sandstone, representing deposition in floodplain and channel settings (Johnson et al., 2006). A reported change of siltstone color, from greenish-gray to reddish-gray, across the vertebrate-defined PTB is associated with a rapid climate change in the current PTME model (Smith and Botha-Brink, 2014). In this model, the terrestrial turnover in the basin is correlated with a change in climate to a more arid condition immediately before the PTME (Smith and Botha-Brink, 2014). The same shift in siltstone coloration is reported from elsewhere (e.g., Russia), and used to interpret a global climatic shift (Benton and Newell, 2014).

Siltstone coloration is thought to be a function of $\mathrm{Fe}^{2+} / \mathrm{Fe}^{3+}$ in the original sediment (prelithification/compaction), and is believed to reflect the oxidizing potential 
of the depositional environment (Coney et al., 2007; Boggs, 2009; Smith and BothaBrink, 2014). Greenish-gray coloration, thought to result from an abundance of $\mathrm{Fe}^{2+}$, is associated with a moist climate and high water table that insulates iron in subaerial sediments from oxidation by atmospheric oxygen. Reddish-gray coloration, on the other hand, is interpreted to represent a high proportion of $\mathrm{Fe}^{3+}$ oxidized by direct contact with air in a dry climate with a low water table (Coney et al., 2007; Boggs, 2009). Although other researchers have reported that coloration is not correlated with climate (Sheldon, 2005), this interpretation continues to be applied to the Karoo succession. The question remains whether the reported siltstone color change in the Karoo Basin is due to differences in the $\mathrm{Fe}^{2+} / \mathrm{Fe}^{3+}$ ratio and, if so, are such ratios the result of the climatic and environmental conditions during and/or soon after silt deposition? If not, what geochemical and/or mineralogical properties of the rocks are responsible for the shift in color, and to what prevailing conditions are these properties linked? This project addresses these questions and tests the climate-change model proposed by Smith and Botha-Brink (2014) in the Karoo Basin by examining the petrography, mineralogy, and geochemistry of siltstones collected from below, at, and above the reported vertebratedefined PTB. 


\section{GEOLOGIC SETTING}

The Karoo Basin, South Africa, covers an area of over $600,000 \mathrm{~km}^{2}$ and is interpreted as a retro-arc, foreland basin formed as the paleo-Pacific plate subducted under the Gondwana plate (Smith, 1995; Fig. 1). The basin fill is known as the Karoo Supergroup, which ranges from Late Carboniferous to Lower Jurassic in age (Fig. 2). The total thickness of the Supergroup may have reached $12 \mathrm{~km}$ before erosion (Johnson et al., 2006). The Karoo Supergroup is subdivided into several groups and formations. From oldest to youngest, these are: the Dwyka, Ecca, and Beaufort Groups, and the Molteno, Elliot, and Clarens Formations (Johnson et al., 2006; Fig. 2), capped by the basalts of the Drakensberg Group. The Beaufort Group is fully terrestrial in origin and is Middle Permian (Day et al., 2015) to Early Triassic in age (Johnson et al., 2006), and the vertebrate-defined PTB is reported in this lithologic unit.

The stratigraphic successions of the Beaufort Group immediately below and above the reported vertebrate-defined PTB have served as the basis for the climatechange model (Smith and Botha-Brink, 2014). The Beaufort Group was deposited after the Karoo Basin became entirely closed without any influence of marine waters and sediment transportation to the ocean (Smith et al., 1993). This fully terrestrial succession is subdivided into the lower Adelaide and upper Tarkastad subgroups, in which pre- and post-turnover vertebrate AZs occurs, respectively (Johnson et al., 2006). The Balfour Formation, the uppermost unit of the Adelaide Subgroup, is comprised of fluvial sandstone and siltstone (Smith and Botha-Brink, 2014; Fig. 2). A reported 3-5-m-thick interval of maroon siltstone/mudstone couplets is reported in the Palingkloof Member, the uppermost unit of the Balfour Formation (Smith and Ward, 2001; Smith and Botha- 
Brink, 2014; Fig. 2). This interval is purported to be an "event bed" that marks the terrestrial extinction event lithologically (Smith and Ward, 2001; Ward et al., 2005; Smith and Botha-Brink, 2014) and is reported to be stratigraphically unique in, and correlatable across, the basin (Smith and Ward, 2001; Smith and Botha-Brink, 2014). Recently, other workers have been unable to identify the same interval in all reported PTB localities and question its utility (Gastaldo et al., 2009; Gastaldo and Neveling, 2012). 


\section{PREVIOUS WORK}

Siltstones in the Beaufort Group were first described as floodplain deposits by Turner (1978) and, since then, the same interpretation has followed for more than three decades. Subsequently, Smith (1980, 1990, 1993, 1995) reinforced and firmly established the idea that these mudrocks were deposited subaerially and were in direct contact with the atmosphere prior to burial. Smith $(1980,1990,1993,1995)$ interpreted fine-grained rocks in the lower Beaufort Group as floodplain deposits, and proposed a three-part model for their origin. In this model, silt accumulated either on levees next to river channels or on the proximal and distal parts of the floodplain. This model was accepted widely among subsequent researchers and applied to upper Beaufort rocks associated with the terrestrial PTME. The interpretation that these siltstones were lithified floodplain sediments lent validity to the use of siltstone coloration as an indicator of climate. It was reasoned that because subaerial deposits are under constant influence of the atmosphere, their features should reflect the climate at the time of deposition (Retallack, 2001).

Most studies centered on the vertebrate-defined PTB in the Karoo Basin employ siltstone color as a climate indicator (e.g., Smith and Ward, 2001; Smith and Botha-Brink, 2014), while few have quantified the geochemistry of these rocks. To date, only five studies report elemental chemistry of Karoo Basin rocks (Retallack et al., 2003; Scheffler et al., 2003, 2006; Coney et al., 2007; Gastaldo et al., 2014).

Retallack et al. (2003) introduced new paleosol categories based on samples taken in the Beaufort Group below to above the vertebrate-defined PTB. They recognized all siltstones found within $25 \mathrm{~m}$ below and $20 \mathrm{~m}$ above the vertebrate-defined PTB as paleosols (fig. 4, Retallack et al., 2003). Their characterization of paleosols was based on 
physical characteristics, such as degree of bioturbation and color, but they also reported major element data in the supplementary information on three paleosol types (Retallack et al., 2003, table 7 supplemental data). Only one entry of major element data is reported for each horizon recognized within a paleosol. Their greenish-gray Bada paleosol is reported to be Permian and interpreted to be representative of a semi-arid climate with a long dry season, and the other two paleosols, weak-red Karie and reddish-gray Kuta, are of Triassic age and subhumid climate (Retallack et al., 2003). These interpretations contrast with the climate-change models (Ward et al., 2000; Smith and Botha-Brink, 2014). Based on their characterization of the siltstones, Retallack et al. (2003) proposed that a long-term climate change from dry to wet conditions occurred before the PTME, but is not large enough in magnitude to cause such catastrophic extinction. Retallack et al. (2003) concluded that the methane release from permafrost and continental shelf methane clathrate reservoirs was the major cause of the extinction, as oxidation of massive quantities of methane would have led to hypoxia, challenging the wetland plants and animals.

Scheffler and collaborators $(2003,2006)$ concentrated on the Dwyka and Ecca Groups, investigating the climate during and after southern hemisphere glaciation. Nevertheless, Scheffler et al. (2006) hinted that an aridification trend began following full continental deglaciation and continued into the late Permian. Their conclusion is based on low values of Chemical Indexes of Alteration (CIA) from a small sample $(\mathrm{N}=4)$ of unnamed siltstones recovered from the Adelaide Subgroup in the Karoo and the Beaufort Group equivalent from the Kalahari basins. CIA is a proxy calculated from the concentrations of alkali and alkaline earth elements, and is an indicator for wet and dry 
soil conditions. Because these elements are mobile during weathering processes, proportional relationships of more or less mobile elements will reflect climate controls on soil development (Scheffler et al., 2006). A low CIA value indicates that the water table in a soil was low and highly fluctuating, and that the sediment weathering was under strong influence of the atmosphere. Conversely, a high CIA value indicates a constantly high water table that insulate the sediment from the atmosphere. CIA is an accurate indicator of climate only if elemental data used in its calculation are obtained from paleosols. Sediments from other depositional environments, such as channel fills, are not affected directly by the atmosphere. Hence, subaqueous deposits do not reflect the conditions of atmospheric climate. Scheffler et al. $(2003,2006)$ provided no interpretation of any depositional environment for their siltstone samples from the Beaufort Group.

Coney et al. (2007) were the first to report extensive elemental data from samples collected below, at, and above the vertebrate-defined PTB. Their samples originated from three localities, including Commando Drift and Wapadsberg Pass in the Eastern Cape Province, two critical sites for PTME studies. Coney et al. (2007) sampled siltstone at regular intervals (at $2 \mathrm{~cm}$ intervals between $7 \mathrm{~m}$ below and 7.5 above the boundary, and at 50-100-cm intervals outside the boundary interval), taking $\geq 10 \mathrm{~g}$ from each stratigraphic horizon. These were finely powdered and analyzed using XRF (Coney et al., 2007). Their data indicate that Fe content increases from below, and attains a maximum concentration immediately above the vertebrate-defined PTB, and then decreases again at Wapadsberg Pass (Coney et al., 2007). However, these authors were unable to duplicate this trend at the other two study sites (Coney et al., 2007). They interpreted the increase 
in Fe concentration as the result of increased iron oxidation and, thus, aridification or climate warming (citing Retallack et al. [2003]) prior to the extinction event (Coney et al., 2007). The contribution of metasomatic alteration to reddening was also considered, but, because of the reported presence of red beds at this interval worldwide, Coney et al. (2007) concluded that a global process would have contributed at least partially to the reddening of these siltstones.

Gastaldo et al. (2014) identified Permian paleosols from Wapadsberg Pass, Eastern Cape Province, in the same interval of Coney et al. (2007), using both physical and chemical parameters. Physical characters of these rocks include the presence of vertical or subvertical fossil roots, rhizoconcretions, and/or horizons of carbonatecemented nodules. Semi-quantitative elemental analyses and other geochemical proxies, coupled with quantitative measurements of Total Organic Content (TOC), were used to differentiate paleosol horizons. They analyzed the olive-green paleosols geochemically, and demonstrated that these have elemental and CIA-K values indicative of wetland environments. This latest Permian evidence is opposite to the prevailing assumption of a more arid environment (Smith and Botha-Brink, 2014) in the Karoo during this interval. 


\section{HYPOTHESES}

The question that this project aims to answer is whether the siltstone color change, recorded across the vertebrate-defined PTB, is influenced by the climate at the time of deposition and/or during early diagenesis (pre-burial). Before any correlation with climate can be assessed, the basis of siltstone coloration must be understood. Three hypotheses that may explain coloration in these rocks are tested. First is whether color differences simply reflect variation in the absolute abundance of iron. The second is whether the relative abundance of oxidized and reduced Fe species acts as a control on color. And, third, whether the suite of minerals present in the siltstone matrix (clay fraction) plays a role in coloration. The mineralogy of silt-sized particles in these samples was not taken into consideration because these grains are mineralogically uniform regardless of sample color (predominantly quartz and feldspars, see Results). Instead, the investigation focused on differences between the two color suites of samples, with the expectation that the differing properties should be related to their coloration. The depositional setting of the sediment also needs to be considered because geochemical conditions operating in subaerial versus subaqueous settings differ vastly, especially with regard to their relationships to atmosphere. 


\section{METHODS}

Siltstone samples were collected from Old Lootsberg Pass (OLP), Eastern Cape Province, and Bethulie, Free State Province, South Africa (Fig. 1). Most samples originated from Old Lootsberg Pass, which is the main focus of this investigation. Samples were examined petrographically, mineralogically, and geochemically to acquire a comprehensive dataset for understanding of the mechanism of coloration and its relation with environmental conditions. Lithological characteristics examined include color and sedimentary structures. Sedimentary structures are a direct result of processes operating in any depositional environment where sediments accumulate or are modified. Therefore, these features are crucial for interpreting the relationship between geochemistry and the environment of deposition. Geochemistry and mineralogy were fully characterized using three different techniques. Bulk elemental composition of each sample was obtained using X-Ray Fluorescence (XRF). Clay mineralogy was determined by X-Ray Diffraction (XRD). Because XRF data do not discriminate oxidized and reduced forms of Fe, selected samples were sent out for Mössbauer spectroscopy, a technique that allows for the quantification of $\mathrm{Fe}^{2+} / \mathrm{Fe}^{3+}$. Once the presence of hematite was confirmed by Mössbauer spectroscopy (See Results), the distribution and morphology of hematite grains in the samples became crucial to understanding their formation and links to coloration. These data were obtained by Scanning Electron Microscopy (SEM) with confirmation of chemical composition using EDS. Total Organic Content (TOC) of several selected samples were also measured; methodology and results of TOC are reported in Appendix B. 


\subsection{Sample Collection}

Field work was conducted in January 2015 at Old Lootsberg Pass (OLP; S $31^{\circ} 47.747^{\prime}$, E $24^{\circ} 48.313^{\prime}$; Fig. 1), a locality used by other workers to identify the terrestrial PTME (Ward et al., 2000, 2005; Smith and Ward, 2001; Smith and BothaBrink, 2014). Hand samples of greenish-gray and reddish-gray siltstone were collected mainly from intervals of thin, interbedded greenish- and reddish-gray siltstone successions. Because massive beds of a single color siltstone are more likely to be the result of late-stage diagenesis (after burial) and metasomatism from Mesozoic dolerite intrusions, instead of reflecting environmental conditions around the time of deposition, thinly interbedded intervals were chosen for this project. Massive, single-colored siltstone beds also were sampled for comparative purposes with thinly bedded intervals. Lithologic successions adjacent to sample sites were photographed and described to record the stratigraphic and sedimentological context.

OLP was chosen as the primary site for the project because it has multiple erosional gullies where relatively well-exposed greenish-gray and reddish-gray siltstones can be correlated locally. Twenty-five samples were collected from above the proposed vertebrate-defined PTB at OLP (Gastaldo et al., 2015) in four stratigraphic sections previously measured and described by R. A. Gastaldo and J. Neveling (Fig. 3). Twentyone samples were collected over a stratigraphic distance of $\sim 30 \mathrm{~m}$ in the Fence section (Table 1; Figs. 3, 4) where the best exposures of interbedded greenish-gray and reddishgray siltstones are located. To test whether the geochemistry or other aspects of siltstones varied laterally, four samples were collected from the East, Waterworn, and Woody Gully sections at correlative horizons (Table 1; Figs. 3, 4). Two additional samples of 
OLP greenish-gray siltstone from the Fence section were collected by Gastaldo and Neveling during January of 2016, at locations that were sampled in January 2015 (Table 1). Because the precise stratigraphic position of the PTME is not identified at OLP by previous workers, no samples were collected at or below the proposed vertebrate-defined PTB.

Siltstone originated from strata at and immediately below the vertebrate-defined PTB was sampled at Bethulie (S 30²5.209', E 26º 15.736'; Fig. 1), Free State Province, another site critical to the PTME model (Smith and Botha-Brink, 2014). Smith and Botha-Brink (fig. 4, 2014) identified and illustrated the PTB and "event bed" at Bethulie, enabling sample collection from the exact same bed. Samples from the "event bed" and a laterally correlative bed were collected by A. N. Churchill and O. K. Battifarano in June, 2015; two are used in the current study (Table 2). In addition, two samples from $105 \mathrm{~cm}$ and $275 \mathrm{~cm}$ below the purported boundary, respectively, were collected by Gastaldo and Neveling in January, 2016, to examine vertical variation in geochemistry (Table 2).

\subsection{Physical Characteristics}

Physical features described from hand samples and thin sections include color, grain size, and primary sedimentary structures. Color was determined in the field and, secondarily, in the laboratory by comparing a fresh surface with a standard Munsell soil color chart, which offers greater standard visual color options and allows for a more precise sample-color determination. Fifteen OLP samples collected in January 2015, two OLP samples collected in January 2016 (marked with ${ }^{\mathrm{a}}$ in Table 1), and all Bethulie samples were sent out for thin section preparation. Thin sections were prepared by Applied Petrographic Services Inc., Greensburg, PA. Grain size was determined using a 
Nikon Eclipse LV100 POL petrographic microscope with NIS-Element BR 3.10 software.

Predominant grain size of the samples was reexamined semi-quantitatively in the laboratory to check whether the field determination accurately reflects the actual sample lithology (Table 1,2). This was accomplished by scanning each thin section under the petrographic microscope and visually estimating the percentage of sand-sized grains using standard guides. Photomicrographs were taken under 10X magnification by a Nikon DS-Ril camera attached to the microscope to visually compare the dominant grain size (coarse or fine silt) and matrix content of each sample. Sedimentary structures were examined in thin sections using a Leica Z6 APO macroscope and in polished hand

samples (marked with ${ }^{\mathrm{f}}$ in Table 1) using an Olympus SZ-40 stereo microscope. Bedding style, the presence of mud chips and burrows, and the intensity of bioturbation were recorded. All thin sections were imaged digitally using a light table employing a natural spectrum lamp, such that all structures within a sample and their relationships could be seen and examined in a single photo.

\subsection{Geochemical and Mineralogical Analyses}

\section{Elemental composition by XRF}

Elemental composition of whole rock samples and the clay fractions of 23 samples were obtained using a Bruker M4 Tornado Micro-XRF spectrometer, and the data were analyzed with the M4 Tornado analytic software (ver. 1.2.0.2687). All samples were run for the region between $0.25 \mathrm{keV}$ and $20.00 \mathrm{keV}$, with a live time of $30 \mathrm{~s}$ per sampling point. Elements included in quantification are: $\mathrm{Si}, \mathrm{Al}, \mathrm{K}, \mathrm{Fe}, \mathrm{Na}, \mathrm{Mg}, \mathrm{Ca}, \mathrm{Ti}$, $\mathrm{Mn}, \mathrm{P}$, and $\mathrm{S}$. 
A first round of XRF-data collection was conducted with 15 to 38 sampling points per siltstone analyzed to obtain a general idea of the elemental composition of each. Only OLP samples collected in January 2015 were included in this round of analysis. Sampling points were chosen through the video system of the XRF spectrometer under 10x magnification. The mode of sampling point selection for each sample was determined by the level of lithologic heterogeneity (such as the presence and density of sub-mm-scale bedding, burrows, and mudchips). For visually homogenous samples, 15 to 28 points were automatically chosen using the grid function of the spectrometer. For heterogeneous samples, at least 28 points were chosen manually in relatively homogenous regions of the samples. The resulting data of each element overlapped greatly between greenish- and reddish-gray siltstones, and the standard errors at $95 \%$ confidence were relatively large due to the low number of sampling points (See Results).

To determine if the geochemical overlap between greenish-gray and reddish-gray siltstone is a result of sampling error, the sample size and resolution were increased in a second round of XRF-data collection. Data were collected only from thin sections where areas of relatively high homogeneity were identified using transmitted-light microscopy. Only OLP samples collected in January 2015 were used. For each thin section, three to eight field-of-view-sized areas were marked on the slide under 100X magnification using the petrographic microscope. Larger numbers of areas were selected for samples that display greater lithologic heterogeneity to better represent the possible geochemical variations in the sample. Data were acquired from a minimum of 233 and a maximum of 649 sampling points per thin section, manually chosen under 100X magnification. The standard errors of the resulting data were reduced greatly (e.g., standard errors for Fe 
concentration were reduced by at least half, see Results); yet, the two color suites still did not appear different with regard to the data range of each element. The concentration of $\mathrm{Si}$ was high for all samples analyzed (66.2 to $75.3 \mathrm{wt} . \%$ as $\mathrm{SiO}_{2}$, see Results), which indicates that the mineralogy of the silt-sized, framework grains may be skewing the results. Because the framework grains of both sample suites are almost purely quartz and feldspars (see Results), when present in high proportions, their elemental composition might bias any variation present in the clay fraction (matrix).

To determine if any variation in elemental composition exists in the matrix of the samples, the clay fractions of 19 OLP samples (marked with ${ }^{\mathrm{b}}$ and ${ }^{\mathrm{c}}$ in Table 1) were separated. Iron oxyhydroxide staining is seen on some weathered samples, so the outer surfaces of all samples were cut off using a rock saw to avoid contamination of the powder used for these slides. Therefore, only large, relatively well-cemented hand samples that allow for such treatment were employed. Samples were hand ground to powders using a mortar and pestle and made into clay slides using the modified Drever's filter-membrane peel technique by Pollastro (1982). These were subjected to XRF to obtain their elemental composition using 48 to 123 sampling points per slide, manually chosen under 10X magnification. Clay slides of OLP samples (marked with ${ }^{b}$ but not ${ }^{c}$ in Table 1) and Bethulie (marked with ${ }^{\mathrm{b}}$ in Table 2) collected in 2016 also were made and analyzed through the same procedure. The 19 OLP clay slides collected in January 2015 were analyzed for clay mineralogy (see below) and will be referred to as the bulk slides, hereafter. 
Clay mineralogy by $X R D$

Clay mineralogy was determined for the 19 OLP samples (marked with ${ }^{\mathrm{c}}$ in Table 1) in the laboratory of Dr. Neil Tabor, Southern Methodist University, Dallas, Texas. Powders were suspended in deionized water $\left(\mathrm{dH}_{2} \mathrm{O}\right)$ in centrifuge tubes and deflocculated in a Chicago Electric Power Tools Industrial 91957 ultrasonic cleaner for roughly 10 minutes. The samples then were placed in an Eppendorf 5810 centrifuge for 3 minutes at $750 \mathrm{ppm}$ to separate the clay and silt fractions. The supernatant of each sample was used to make clay slides following Pollastro's (1982) method. Four treatments - $\mathrm{KCl}, \mathrm{MgCl}_{2}$, Glycerol, and heat treatments - were applied to the clay films before being transferred onto petrographic slides. These treatments allow for the identification of specific clay minerals. The procedures for the three chemical treatments are presented in Table 3. Three clay slides were made for each sample to be treated with each of the chemical treatments. A heat treatment was applied to $\mathrm{KCl}$-treated slides after they were run for XRD data collection. These slides were baked at $550^{\circ} \mathrm{C}$ for 3 hours. Comparison of the spectra obtained from heated and unheated KCl-treated slides allows for the identification and distinction between kaolinite and chlorite. Vermiculite and smectites are identified and differentiated by comparing the spectra from $\mathrm{MgCl}_{2}$ - and glycerol-treated slides. In addition to the 19 bulk slides, 57 treated clay slides were made. All slides were analyzed with a Rigaku Ultima III X-ray diffractometer in the Bragg-Brentano focusing beam configuration with a $\mathrm{Cu} X$-ray source. Each sample was scanned for the $2 \theta$ range of $2^{\circ}$ to $30^{\circ}$, with a scan speed of $1^{\circ} 2 \theta / \mathrm{min}$ and a step width of $0.01^{\circ} 2 \theta$. After XRD data collection, all $\mathrm{KCl}$-treated slides were heated at $550^{\circ} \mathrm{C}$ for 3 hours and analyzed using the same procedure. Analysis of XRD data was conducted with the Rigaku PDXL2 software. 
$\mathrm{Fe}^{2+} / \mathrm{Fe}^{3+}$ Concentrations by Mössbauer Spectroscopy

Four OLP samples (marked with ${ }^{\mathrm{d}}$ in Table 1) from the Fence section and two Bethulie samples (marked with ${ }^{\mathrm{d}}$ in Table 2) were powdered, sieved, and sent to Dr. Darby Dyer's laboratory at Mount Holyoke College for Mössbauer spectroscopic analysis in August 2015. The four OLP samples were chosen on the basis of sample color, grain size, sedimentary structures, and stratigraphic position (Table 1; Fig. 4). JL109-3B and JL109-10 are from the base of the Fence section; JL109-10 was collected $\sim 1$ m below where JL109-3B originates (Table 1; Fig. 4). JL109-3B is reddish-gray (5YR 3/1) in color, while JL109-10 is mostly greenish-gray (5Y 4/1) with a thin reddish-gray layer at the bottom (Table 1; Fig. 5A, B). JL109-16 and JL109-18 were collected from the same interval at the top of the Fence section (Table 1; Fig. 4). JL109-16 displays the same color as JL109-10 (greenish-gray, 5Y 4/1) but has a thin reddish-gray layer at the top (Table 1; Fig. 5C). JL109-18 has the same color as JL109-3B (reddish-gray, 5YR 3/1; Table 1; Fig. 5D). Only the greenish-gray parts of JL109-16 and JL109-18 were powdered and submitted for Mössbauer spectroscopy. The two Bethulie samples (B.S.7.6 and B.S.7.11) were chosen because they were collected at the vertebrate-defined PTB reported by Smith and Botha-Brink (2014). Sample B.S.7.6 is a reddish-gray (5YR 4/1) siltstone collected at the site figured by Smith and Botha-Brink (2014, fig. 4; Fig. 6A). B.S.7.11 is a greenish-gray (10Y $6 / 2)$ siltstone collected $\sim 300 \mathrm{~m}$ to the northeast in the laterally equivalent and correlative bed of B.S.7.6 sample site (Fig. 6B). Both samples are sandy and contain higher framework grain content compared to other thin sections; this is especially true for B.S.7.11 (see Results; Fig. 6). 
To test if a darker reddish-gray color is related to a higher percentage of ferric iron in the form of hematite, or potentially other iron oxides, two additional samples, JL110-1 and JL161-4 (marked with ${ }^{\mathrm{e}}$ in Tables 1 and 2), were sent to Mount Holyoke for Mössbauer spectroscopy. JL110-1 was chosen because its color is the closest to the "maroon" color (2.5 YR 2.5/4) reported by Smith and Botha-Brink (2014; Fig. 7B). The abundance of Fe in JL110-1 is not noticeably higher than the other samples (See Results). JL161-4 was heat-treated before it was shipped to determine the mineralogical change that resulted from the heating process. Powders of JL161-4 were subjected to the same procedure undertaken at SMU to separate the clay-sized particles from coarser grains. Deflocculation and centrifuging were conducted with an ultrasonic cleaner Sonicor SC$150 \mathrm{~T}$ and an Eppendorf $5804 \mathrm{R}$, respectively. Heat treatment was done with a Carbolite ELF 11/14B chamber furnace. The results from the analyses of these two samples are not available yet.

The methods undertaken for Mössbauer Spectroscopy in Dr. Dyer's laboratory follow:

Approximately $40 \mathrm{mg}$ of the sample were gently mixed with sugar, then heaped in a sample holder confined by kapton tape. Mössbauer spectra were acquired at $295 \mathrm{~K}$ using a source of $90 \mathrm{mCi} 57 \mathrm{Co}$ in $\mathrm{Rh}$ on a SEE Co. (formerly WEB Research Co.) model WT302 spectrometer (Mount Holyoke College). For each sample, the fraction of the baseline due to the Compton scattering of $122 \mathrm{keV}$ gammas by electrons inside the detector was determined by measuring the count rate with and without a 14.4-keV stop filter ( $\sim 2 \mathrm{~mm}$ of Al foil) in the gamma beam. Comptoncorrected absorption was calculated for each individual spectrum using the formulation $\mathrm{A} /(1-\mathrm{b})$, where $\mathrm{b}$ is the Compton fraction and $\mathrm{A}$ is the uncorrected absorption. This correction does not change the results of the fits per se but does allow accurate determination of \% absorption in the spectra. It is necessary because the range of energy deposited in the detector by Compton events extends from $0 \mathrm{keV}$ to $40 \mathrm{keV}$, overlapping both the $14 \mathrm{keV}$ and $2 \mathrm{keV}$ energies deposited by the $14 \mathrm{keV}$ gammas. 
Run times were 24-48 hours. Spectra were collected in 2048 channels and corrected for nonlinearity via interpolation to a linear velocity scale, which is defined by the spectrum of the $25 \mu \mathrm{m}$ Fe foil used for calibration. The WMOSS algorithm fits a straight line to the points defined by the published values of the Fe metal peak positions (as y values) and the observed positions in channels ( $\mathrm{x}$ values). Data were then folded before fitting, using the WMOSS Auto-fold procedure that folds the spectrum about the channel value that produces the minimum least squares sum difference between the first half of the spectrum and the reflected second half of the spectrum.

Mössbauer spectra were modeled using the Mex_disdd program, which was acquired from the University of Ghent courtesy of E. DeGrave. The program uses Lorentzian line shapes and solves full hyperfine interaction Hamiltonians for isomer shift and quadrupole splitting but uses multiple distributions for magnetically split spectral components, where the value of the magnetic field is given as the value for the most heavily weighted distribution. Errors on isomer shift, quadrupole splitting, and line widths are $\pm 0.02-0.03 \mathrm{~mm} / \mathrm{s}$ for the doublets and sextets in these spectra, and errors on hyperfine fields are $\pm 2-3 \mathrm{kOe}$. Errors on total $\% \mathrm{Fe}^{3+}$ are \pm 1 $5 \%$ absolute based on repeated fits to the same spectra, with a detection limit for $\mathrm{Fe}^{3+}$ of roughly $1 \%$.

\subsection{SEM Imaging of Thin Sections}

SEM imaging was undertaken at the University of Maine-Orono under the instruction by Dr. Martin Yates. Samples that were confirmed to have hematite by Mössbauer spectroscopy (JL109-16, JL109-18, and B.S.7.6, see Results) were scanned using a Tescan Vega II XMU tungsten filament scanning electron microscope with backscatter capabilities to determine the distribution and morphology of metal-rich oxides (which appear as white grains of varying brightness) and silicates. Thin sections were carbon-coated before scanning for better focusing and resolution. Mineralogy was determined based on semi-quantitative elemental composition data obtained by the

EDAX Pegasus EDS system attached to the SEM. Digital images and EDS X-ray point spectra of representative grains were collected. 


\subsection{Data Analyses}

Data obtained from XRF were processed in Microsoft Excel for descriptive statistics, bivariant scatter plots, and weathering indices. The Mann_Whitney U-test was performed between greenish-gray and reddish-gray samples for mean concentrations of major elements obtained during all three rounds of XRF-data acquisition. Mean values and standard errors were calculated using the Data Analysis tool. Fe concentrations (quantified as $\mathrm{FeO}$ ) obtained in each round of analyses were plotted against $\mathrm{Si}$ (quantified as $\mathrm{SiO}_{2}$ ). Scatter plots of Fe vs. Si grouped by color suites were made for data obtained in the three rounds of XRF analyses. Scatter plots of Fe vs. Si grouped by sedimentary structure groups were made for clay-fraction data obtained in the third round of analyses. Bivariate plots of mean major-element concentrations vs. Fe were made for datasets from the second and third rounds of analyses. Weathering indices, including base loss ([Na, $\mathrm{Ca} / \mathrm{Ti}$ ) and CIA-K, were calculated using clay fraction data following the methods of Gastaldo et al. (2014). 


\section{RESULTS}

\subsection{Lithologic Characteristics}

\section{Color}

Although categorized as either greenish-gray or reddish-gray for the sake of convenience, color of the samples varies greatly within each color suite (Tables 1,2). Greenish-colored samples are distributed across several different hues. Out of the fifteen samples that are entirely or partially greenish-colored, seven are greenish gray (with a hue of $10 \mathrm{Y}, 5 \mathrm{BG}$ or $5 \mathrm{GY})$, and five are olive to light olive gray (5Y 4/2-6/2). The remaining three samples are dark gray $(5 \mathrm{Y} 4 / 1)$ or grayish brown $(2.5 \mathrm{Y} 5 / 2$, an intermediate color between greenish- and reddish-gray). Samples with reddish coloration also are not restricted to a single hue. Out of nineteen samples that are entirely or partially reddish-colored, eleven are dark to very dark gray (5YR 4/1-3/1, one sample is 10YR 4/1). Five samples are dark reddish gray (10R 3/1-4/1), and the remaining three samples are brown (7.5YR 4/2), gray (5YR 5/1), and dusky red (2.5YR 3/2). All color descriptions are taken from the standard Munsell soil color chart used to characterize these colors. It is worth noting that the color description "dark gray" is used for colors with either a reddish or a greenish hue.

\section{Sedimentary Structures}

Similar to sample color, the types of primary sedimentary structures in each sample also vary. Sedimentary structures were recorded for all thin sections, as well as for polished hand samples that do not have corresponding thin sections but have the clay fractions separated and analyzed for geochemistry (i.e., all samples labeled with ${ }^{\mathrm{f}}$ in Tables 1 and 2). Details of the sedimentary structures in each sample appear in Table 4, 
and photomicrographs of representative thin sections are found in Figure 7 (see Appendix for additional photomicrographs of thin sections). Most samples contain intact or partially-preserved thin, sub-mm- to mm-scale beds (including fining-up cycles) that are visible throughout or in a part of the sample (Table 4; Fig. 5A, D; Fig. 7A). Mud chips, where present, vary in size, from $<1 \mathrm{~mm}$ (e.g., JL110-1, Fig. 7B) to $>5 \mathrm{~mm}$ (e.g., JL110-2, Fig. 7C) in length, and in abundance (Table 4). In several samples, mud chips are found only at the base of the fining-up cycles within the sample, or at the base of the entire thin section/hand sample (i.e., when the entire thin section/hand sample represents a single fining-up cycle or part of a fining-up cycle; Table 4; e.g., JL117-1, Fig. 7D).

In addition to primary sedimentary structures, there is evidence of bioturbation in several samples. Burrow diameters range from $<1 \mathrm{~mm}$ to $\sim 5 \mathrm{~mm}$ in diameter (e.g., JL109-3B, Fig. 5A; Table 4), and these are oriented vertically, subvertically, or horizontally. The density of burrows varies but is not quantified for each sample. This is because intensity of bioturbation is not solely characterized by the presence and density of burrows. Rather, bioturbation intensity in any sample primarily is based on the presence and preservation of primary beds, in combination with burrow density (Table 4). The intensity of bioturbation is quantified using the Droser-Bottjer ichnofabric index (I-I; Droser and Bottjer, 1986).

All samples examined for sedimentary structures (both thin sections and polished hand samples) can be divided into three groups. Several samples display vastly different structures in different parts of the sample (Table 4), and each interval is assigned to a different group, instead of the entire sample being assigned to a single group. For the sake of convenience, samples of a single set of sedimentary structures, and intervals of 
individual samples displaying different sedimentary structures, are both referred to simply as sample for the remainder of this section. Group I samples contain undisturbed bedding and no burrows or only sparse burrows (e.g., JL109-3B and JL109-18, Fig. 5A, D; JL109-8, Fig. 7A); these have a bioturbation intensity of I-I 1 (undisturbed) to $2(0 \sim 10 \%$ disturbed). If mud chips are present, they occur at the base of beds. Group II samples exhibit partially-preserved bedding structures and a higher number of burrows when compared to Group I (e.g., JL109-11, Fig. 7E). Here, the intensity of bioturbation is higher (as evidenced by a greater proportion of disturbed bedding) and can reach I-I 3 (10 $40 \%$ disturbed). If mud chips are present, they are distributed throughout the sample. Group III samples have no primary sedimentary structures and the absence of bedding is considered to be the result of intense bioturbation (I-I 4 to $5,40 \sim 60 \%$ to $60 \sim 100 \%$ disturbed; e.g., JL110-1 and JL110-2, Figs. 7B, C). The identification of individual burrows in these samples often is difficult because the sediment is homogenized. Mud chips, if present, are often of medium to high density (occupying 10 20\% of total surface area).

\section{Other Microscopic Observations}

Unique features in several samples are worth special attention because of their importance in interpretations (see Discussion). For example, JL161-1 has defined, although faint, crossbedding, and laminae of $\mu \mathrm{m}$-sized oxide grains that resemble organic-rich mud drapes at first glance (Fig. 7F). The edges of these grains are not defined clearly under the microscope, and these grains were not investigated using SEM. JL109-16, one sample sent out for Mössbauer spectroscopy, preserves burrows in the greenish-gray interval that have reddish-gray rinds. B.S.7.6 and B.S.7.11 are both sandy, 
and B.S.7.11 has a higher framework grain content compared to all other thin sections (Fig. 6). Despite a high degree of variation in sedimentary structures, shape of silt grains is uniform in all samples. All silt grains are highly angular and most consist of quartz, while a smaller portion are feldspars.

\subsection{Elemental Composition}

Data from the three rounds of XRF analyses are of variable levels of accuracy (Tables 5-7). The first round of XRF analyses was aimed at obtaining a general idea of the elemental composition of the samples. Therefore, only a small number of sampling points was selected for each. These data show that greenish-gray and reddish-gray samples are significantly different in the concentrations of $\mathrm{Na}, \mathrm{Mg}, \mathrm{Si}, \mathrm{K}, \mathrm{Ti}$, and $\mathrm{Mn}$ (Mann-Whitney U test results reported in Table 5). When Fe is plotted against Si concentration, greenish-gray and reddish-gray samples are not segregated from each other (Fig. 8A). However, this dataset had a relatively large margin of uncertainty as determined from values for standard error (Table 5). Subsequent microscopic examination revealed that silt grains in these samples are all quartz and feldspars, which may have biased the results toward a higher Si concentration and obscured any compositional variations in the matrix of the rocks.

The second set of XRF analyses focused on selected areas of thin sections. These samples are similar in grain size and amount of matrix. A larger number of XRF sampling points was applied to these samples which resulted in a reduction in the standard errors (Table 6). However, data obtained from this round are not significantly different between greenish-gray and reddish-gray samples in any major element 
concentration (Mann-Whitney $\mathrm{U}$ test results reported in Table 6), and Si concentrations remain high.

The final round of data acquisition focused only on prepared clay slides where silt-sized grains were eliminated to avoid skewing of the results. Although fewer sampling points were used, standard errors are equal to or smaller when compared to the second round (Tables 6, 7; Figs. 8B, C), and the cloud of data points is less scattered (Fig. 9). The concentration of $\mathrm{Si}$ is lower whereas the Al concentration is higher when compared to data from the second round of analyses (Tables 6, 7). Greenish-gray and reddish-gray samples are significantly different in the concentrations of $\mathrm{Na}, \mathrm{Ti}$, and $\mathrm{Mn}$ (Mann-Whitney $U$ test results reported in Table 7). Within the reddish-gray suite, three samples (JL109-3, 4, 7) appear to be outliers from the cloud in which the majority of the samples plot (Figs. 10B, C).

Elemental trends in data acquired in the second and third analyses are in strong contrast. Second-round data show relatively good linear correlation between Fe concentration and the concentrations of other major elements (Fig. 11). $\mathrm{R}^{2}$ values of six out of eight major element-trend lines are equal to, or higher than, 0.37 and can be as high as 0.77 (for $\mathrm{MgO}$ vs. FeO; Fig. 11). However, for data acquired in the third round of analyses where only the clay fraction was assessed, the highest $\mathrm{R}^{2}$ value is only 0.33 (for $\mathrm{SiO}_{2}$ vs. FeO; Fig. 11). Five out of eight element-trend lines have $\mathrm{R}^{2}$ values lower than 0.15 (Fig. 11).

\subsection{Clay Mineralogy}

Despite the apparent color differences, all samples are uniform in the mineralogy of their clay-sized fractions (Table 8). The XRD spectra obtained from the 19 samples all 
display the same pattern (e.g., Fig. 12). Ten peaks were present on the spectra obtained from KCl-treated slides (Fig. 12A). After heat treatment the $7 \AA, 4.71 \AA$, and $3.53 \AA$ peaks completely collapse (Fig. 12B). $\mathrm{MgCl}_{2}$ and Glycerol treatment did not have any visible effect in the spectra (Figs. 12C, D). Based on the spectra obtained, the only minerals present at detectable abundance (> $1 \mathrm{wt} . \%)$ in all samples are chlorite, illite, quartz, and feldspars (Table 8). The bulk slides prepared at Colby without deflocculation and centrifugation have higher quartz and feldspar peaks compared to the slides prepared at SMU (Fig. 13). The range of hematite peaks also was scanned in several samples; yet, no hematite peaks were observed on the spectra. The low concentrations of hematite can account for this result (see Discussion).

\section{$6.4 \mathrm{Fe}^{2+}$ and $\mathrm{Fe}^{3+}$}

Mössbauer spectroscopy provides quantitative data on $\mathrm{Fe}^{2+}$ and $\mathrm{Fe}^{3+}$ concentrations in the sample suite (Table 9). All samples, regardless of color, have more than $50 \%$ of total $\mathrm{Fe}$ in the oxidized state, except for B.S.7.11 which is greenish gray (Table 9). Reddish-gray samples have more $\mathrm{Fe}^{3+}$ when compared to greenish-gray samples, and at least $15 \%$ of total $\mathrm{Fe}$ is in the form of dispersed fine-grained hematite (Table 9). However, hematite is not restricted only to reddish-gray siltstone but also is found in JL109-16 and represents 7\% of total Fe (Table 9). The remaining two greenishgray samples contain no hematite (Table 9).

\subsection{SEM imaging}

The distribution and morphology of various oxides were qualitatively examined under SEM with species identification based on semi-quantitative elemental compositions obtained from EDS. However, because X-ray scattering is strong due to the 
uneven surface texture of the unpolished thin-section, X-rays scattered and reflected by surrounding minerals also were received by the instrument. Therefore, EDS data are considered to be indicative of the mineral composition but cannot be regarded as unequivocal evidence for species identification.

Hematite primarily occurs as coatings on clay mineral plates. The size of hematite coatings is highly variable, ranging from $\sim 5 \mu \mathrm{m}$ to as large as $\sim 100 \mu \mathrm{m}$ (Figs. 14A, B), although sizes $<20 \mu \mathrm{m}$ were more commonly seen. Coated clay minerals are mostly illite, although coatings on chlorite also were found (Table 10, Fig. 15 for locations of data acquisition). Individual hematite crystals generally are rare and small $(\sim 5 \mu \mathrm{m}$ to $\sim 20 \mu \mathrm{m})$ (Figs. 14C, D), although one larger crystal ( 125 $\mu \mathrm{m}$ in length) occurs in B.S.7.6 (5YR 4/1, dark gray). All hematite evaluated with EDS contains low concentrations of Ti (e.g., Table 11). Other than hematite, EDS data indicate the presence of ilmenite, rutile, and titanite (Table 11). The presence of magnetite is confirmed by paleomagnetic total magnetic susceptibility data (J. W. Geissman, personal communication). The compositional data of a suspected magnetite grain is presented in Table 11, although this grain may be misidentified because of its similar composition to ilmenite. Titanite and rutile also are found as coatings on clays (Figs. 16A, B), while ilmenite is more often found as individual crystals (Fig. 16C). Both titanite and rutile were found in the most reddish-brown areas of JL109-16 (bottom of the top dark-gray [5YR 4/1] beds; Fig. 5C). Magnetite is uncommon when compared to the other oxides and only occurs as detrital crystals (Fig. 16D). 


\section{DISCUSSION}

The relationships between siltstone coloration, geochemistry, and prevailing climatic conditions around the time of deposition has intrigued generations of geologists. Results of this current study show tremendous variation in Karoo siltstone colors and sedimentary structures, and surprising uniformity in the mineralogy and geochemistry of these rocks. These results pose questions about the validity of previous interpretations of the depositional environment, climates represented by, and the mechanisms of coloration of Karoo siltstones bounding the vertebrate-defined Permian-Triassic boundary event.

\subsection{Variations in Color}

Considerable color differences exist in each sample suite. Ward et al. (2000, 2005), Smith and Ward (2001), Smith and Botha (2005), and others have described the reddish-colored siltstones as "maroon" or "rubified." Smith and Botha-Brink (2014) stated that these generic colors correspond to Munsell designations of 2.5YR 2.5/4 (dark reddish brown) for maroon mudrocks in the "event bed" and 2.5YR 3/6 (dark red) for earliest Triassic maroon mud rocks. However, only one sample collected from the sections described by these authors has a color in the same hue (JL110-1, 2.5YR 3/2). Most samples are more appropriately described as dark gray (5YR 4/1-3/1) and reddishgray (10R 3/1-4/1), and, in general, much "duller" with a stronger grayish hue than "maroon." All the above color characterizations were conducted in the laboratory. When described in the field, the rocks generally appear even duller with lower contrast between colors due to the intense direct sunlight. For the sake of convenience, colors in the following discussion still will be referred to as reddish-gray and greenish-gray. But, it should be emphasized that tremendous variation exists in the coloration of Karoo 
siltstones, unlike the impression one would acquire from previously published characterizations.

\subsection{Variations in Depositional Environments}

Previous interpretations of the siltstones of the Adelaide Subgroup (Smith, 1980, 1990, 1993, 1995) envision a tripartite model for the depositional setting in which these accumulated. Siltstones are reported to represent only overbank deposits on channel levees and the floodplain. Levee deposits are reported to be comprised of interbedded sandstone and greenish-gray mudrock, and represent the coarsest overbank deposits (Smith, 1980, 1990). The majority of siltstones are considered to be floodplain deposits, although Smith (1980) distinguished between proximal and distal floodplain settings based on subtle grainsize variation. More interestingly, he reported repetitive, 1-m-thick, color sequences from the proximal siltstone facies, grading from greenish-gray siltstone at the base, to greenish and mottled reddish rocks overlain by massive reddish-grey siltstone.

Smith and Botha-Brink (2014) focused on the vertical transition from massive gray mudrock, to massive mottled maroon-gray rock, laminated reddish-brown mudrock (the "event bed"), and massive maroon siltstone at their study sites, which include both OLP and Bethulie. The tripartite model is not mentioned in the study by Smith and Botha-Brink (2014), but the interpretation that all mudrock were deposited on the floodplain was continued. The earliest Triassic massive maroon-siltstone facies of Smith and Botha-Brink (2014) corresponds to the stratigraphic interval from which all OLP samples were collected. Smith and Botha-Brink (2014) attribute the "thick beds of red uniform textured silt (p. 105)" to an eolian or loessic origin, stating that at least a portion 
of the massive maroon siltstone was deposited by "cyclones moving across dry floodplain surfaces (p. 106)," which they interpreted as an indicator of a dry climate. Siltstone characteristics described in the current study result in the conclusion that these deposits more likely represent a flowing-water environment.

Sedimentary structures in the OLP and Bethulie samples include planar bedding, crossbedding, mud chips, and burrows, and are indicative of a subaqueous depositional setting. Undisturbed beds in samples that comprise Groups I (e.g., JL109-8 and JL161-1, Figs. 7A, F) indicate that the sediment accumulated in an environment with flowing water, likely an in-channel, fluvial setting. The presence of small-scale fining-up cycles (e.g., JL117-1, Fig. 7D) and crossbedding (Figs. 7A, F) are indicative of sedimentary pulses of both bedload and suspension load deposition in a subaqueous environment. If these sediments had been exposed for extended periods to subaerial conditions on the floodplain, they would appear homogeneous as a function of intense bioturbation either as a consequence of rooting or either invertebrate (e.g., Katbergia; Gastaldo and Rolerson, 2008) or vertebrate (Retallack et al. 2003; Bordy et al., 2011) burrowing. Primary bedding features found in Group I samples represent sediments that were deposited in a fluvial setting with either relatively continuous discharge or episodic water flow that prevented bioturbation in these samples (Table 4).

Although Groups II and III samples are more intensely bioturbated, deposition of the original sediment in flowing water environment is still plausible. Modern rivers often have high sediment loads due to anthropogenic activities that induce more intense erosion (Golosov et al., 2014). Such high sediment flux would prevent animal colonization in channel deposits, because filter feeding and oxygen intake would be impaired by 
sediment in suspension. Therefore, based on conditions in modern fluvial systems, partially bioturbated Group II samples (e.g., JL109-11, Fig. 7E) would represent low water velocity and sediment influx, and intensely bioturbated Group III samples (e.g., JL110-1 and JL110-2, Figs. 7B, C) likely indicates floodplain deposition. However, in the Permian without anthropogenic influence, erosion rate was likely low enough that burrowing activities could still take place within bedload sediments. Additional support of in-channel, fluvial depositional environment for bioturbated samples is their close stratigraphic relation with Group I samples. For example, samples JL109-7 to 10 were collected from an interval of less than a meter in thickness (between $+10.9 \mathrm{~m}$ and +11.7 $\mathrm{m}$ in the Fence section, Table 1). Yet, the structures within these samples change from Group I, to III, to II, and back to III (Table 4; Figs. 5B and 7A). In JL109-10, Group II structure transitions upward into Group III structure category within $5 \mathrm{~cm}$, without an erosional contact separating the two groups (Fig. 5B). If moderately bioturbated Group II structures represent deposition in quiet water, and intensely bioturbated Group III structures represent floodplain deposition, such rapid transitions between different depositional environments in the time recorded by less than a meter of rock is rather unlikely. Therefore, an in-channel, fluvial depositional environment for bioturbated samples is plausible and likely, although their position on a floodplain cannot be excluded by available data.

\subsection{Geochemistry and Mineralogy of Samples}

The current study is the first to report comprehensive and extensive data on the geochemistry and mineralogy of Karoo siltstones. Data are first compared with 
previously published datasets. Thereafter, the relationships between

geochemistry/mineralogy, color, and depositional environments are explored.

Comparison with previously published elemental data

Elemental data obtained in the current project fall in the same general range as those previously published for the Wapadsberg Pass area (Coney et al., 2007), from where the most comprehensive Karoo dataset was reported. Clay-fraction data from Old Lootsberg Pass and Bethulie mostly cluster in the same general range of Coney et al.'s (2007) data, except for $\mathrm{Al}$ and $\mathrm{K}$, which plot higher in this study than those reported by Coney et al. (2007; Fig. 17). This disparity can be explained by the different methods employed in these two studies. Due to technological limitations, Coney et al. (2007) analyzed the elemental chemistry of the powdered, whole-rock samples using XRF, analyzing only one sampling point per sample without isolating the clay fractions. Al and $\mathrm{K}$ are two elements especially abundant in clay minerals; therefore, the Si-rich silt grains can disguise the variations in the clay fractions. Coney et al.'s (2007) dataset also contains more outliers than does the dataset presented here, which can again be explained by their methodology. The presence or absence of primary structures, the degree of bioturbation, or any other features, including color, are unreported in the study by Coney et al. (2007). Hence, when samples were powdered, any structure with a high concentration of specific elements, such as a small hematite nodule, would be homogenized. The powdered sample size used by Coney et al. (2007) was also small ( $\geq$ $10 \mathrm{~g}$ ), and when such small samples are analyzed, any anomaly would strongly affect the overall elemental chemistry. 
Coney et al. (2007, their fig. 5) plot a trend in Fe concentration at Old Wapadsberg Pass beginning below Ward et al.'s (2005) vertebrate-defined PTB to several meters above it. They found that the Fe content increases up-section and reaches its maximum immediately above the vertebrate-defined PTB (Coney et al., 2007). Comparisons of whole rock and clay-fraction data in this study suggest that this trend in Fe concentration may be an artifact resulting from the analysis of both framework and matrix grains. Figure 11 depicts relatively good trends in most major elements when whole-sample data are plotted against Fe concentration (quantified as FeO). However, once the silt grains of uniform mineralogy (predominantly quartz with a small portion being feldspars) are removed before XRF analyses, most of the trends seen in wholesample data are greatly reduced in their $\mathrm{R}^{2}$ values, indicating weaker correlations between concentrations of different elements (Fig. 17). The exception is in Ca data.

The greater $\mathrm{R}^{2}$ value for the trend between $\mathrm{Ca}$ and $\mathrm{Fe}$ in the clay fractions (Fig. 18F) may be due to the exclusion of sub-mm-scale calcareous nodules during clay-silt separation. In the dataset obtained during the second round of XRF analyses, a portion of sampling points in some samples showed unusually high $\mathrm{Ca}$ concentrations (e.g., up to 15.86 wt. $\%$ as $\mathrm{CaO}$ in JL109-11 thin section). The presence of such clasts, or cement, in the clay fraction may be responsible for the scattering in the resulting data. In summary, the Fe concentration trend observed in Coney et al.'s (2007) Old Wapadsberg Pass data simply may be due to variation in the silt-clay fraction ratio across samples. This conclusion is supported by the fact that Coney et al. (2007) were unable to observe the same trends in elemental geochemistry at other PTB localities which implies that these are artifacts of sample petrology. 
Elemental data reported by Retallack et al. (2003) for Karoo paleosols are different in $\mathrm{Si}$ and Fe concentrations from the data obtained during the first and second rounds of XRF analyses in the current project. Retallack et al. (2003) described all siltstones found within $20 \mathrm{~m}$ below and above the vertebrate-defined PTB as paleosols. They reported major element concentrations for the horizons of three paleosol types (Bada-Permian, Karie-Triassic, and Kuta-Triassic) found immediately below and above the vertebrate-defined PTB. Several problems exist in these data. First, they did not specify the collection sites for the hand samples used for XRF and titration analyses. Based on measured stratigraphic sections presented in their fig. 4 (Retallack et al., 2003), the Karie and Kuta paleosols (within $20 \mathrm{~m}$ above the boundary) were found in equivalent stratigraphic intervals to where 15 OLP samples were collected (Table 1). Therefore, hypothetically, major element data obtained from these paleosols should fall in the same range as those obtained in the current project. The above three paleosols have similar ranges for the concentrations of each major element, with the exception of the Bk horizon of Kuta paleosol, which contains over $22 \%$ of $\mathrm{Ca}$ (quantified as $\mathrm{CaO}$ ) due to the presence of calcareous nodules (Retallack et al., 2003). Si concentrations (quantified as $\mathrm{SiO}_{2}$ ) of the three paleosols fall in the range of 63.18 to 70.45 wt.\% (Retallack et al., 2003). Gross Fe concentrations (quantified as $\mathrm{FeO}$ ) of the three paleosols were calculated from concentrations of $\mathrm{Fe}^{2+}$ and $\mathrm{Fe}^{3+}$ (respectively quantified as $\mathrm{FeO}$ and $\mathrm{Fe}_{2} \mathrm{O}_{3}$ ) provided by Retallack et al. (2003). Most of the paleosol horizons have gross Fe concentrations greater than $4.45 \mathrm{wt} . \%$, with the highest value being $6.79 \mathrm{wt} \%$. Al concentrations (quantified as $\mathrm{Al}_{2} \mathrm{O}_{3}$ ) fall in the range of 13.07 to $15.57 \mathrm{wt} . \%$ for the paleosols (Retallack et al., 2003). When compared with the whole-rock data for the OLP samples from the 
same stratigraphic interval, Si concentrations of Retallack et al.'s (2003) paleosols are slightly lower, while Fe concentrations are much higher (Table 6). Al concentrations are in the same general range for the two datasets. When compared with the clay-fraction data of the OLP samples from the same stratigraphic interval, gross Fe concentrations for the paleosols of Retallack et al. (2003) still exceeds the Fe concentrations recorded from the OLP sample clay fractions, whereas Al concentrations of the paleosols are lower (Table 7). Retallack et al. (2003, fig. 5) reported a high concentration of feldspars in their paleosols accounting for $\sim 25 \%$ of the rocks. Silt grains of the OLP samples examined in the current project are predominantly quartz, with a small portion being feldspars. This mineralogical difference may explain the lower Si concentrations of the paleosols when compared to the whole-sample data of this project and lower Al concentrations when compared to the clay-fraction data.

\section{Chemistry by color groups}

Element concentrations that are significantly different between the greenish- and reddish-gray samples vary between rounds of XRF analyses, likely due to data acquisition methods. In the first round of analyses, $\mathrm{Na}, \mathrm{Mg}, \mathrm{Si}, \mathrm{K}, \mathrm{Ti}$, and $\mathrm{Fe}$ showed significant difference between the two color suites (Table 5). However, in the dataset obtained in the second round, greenish-gray and reddish-gray samples are not statistically different in any major element concentration (Table 6). In the third round, concentrations of $\mathrm{Na}, \mathrm{Ti}$, and $\mathrm{Mn}$ are significantly different between greenish- and reddish-gray samples (Table 7). The fact that no single element consistently shows a statistical difference between the two color suites throughout the three rounds of XRF-data acquisition indicates that different sampling methods for the three rounds may explain the variance in 
statistical difference. The first round of analyses was conducted with fewer sampling points per sample $(<50)$, while over 200 sampling points were used per sample in the second round. Any point in a sample with unusually high/low concentration of a major element would skew the mean value if the number of sampling points was small. The largest numbers of sampling points per thin section were used during the second round of XRF analyses. These sampling points were deliberately chosen in different sedimentary structures present in a sample, such that the resulting data would represent sample heterogeneity. Therefore, the calculation of mean value likely "homogenized" the potential compositional variation present in different portions of a sample, resulting in no statistical difference in any major element between the two color suites. In addition, because the size of the X-ray beam is wider than the area between silt grains, these larger clasts inevitably were scanned in thin sections during the first and second rounds of data acquisition, which also may bias the data. The third round of analyses eliminated any influence from the composition of silt-sized fraction and differences in silt-clay ratio. Hence, data from this round should represent the true compositional variations of the samples. The statistical difference in Ti concentration may be due to the presence/higher abundance of minerals containing the element in the reddish-gray samples (See below). The significant difference of $\mathrm{Mn}$ between the two colored siltstones may be related to the reddish coloration based on results obtained from a Bethulie sample not included in the current study (B.S.7.11). In this sample, $\mathrm{Mn}$ is found in abnormally high concentrations ( $5 \%$ or higher) in the reddish-brown portion of this sample (unpublished data). The significant difference in Na concentration between the two color suites requires further investigation to identify the potential cause(s). 
Although the data clouds in bivariate plots of reddish-gray and greenish-gray samples overlap (e.g., Fe vs. Si concentrations, Fig. 10), reddish-gray samples do not cluster as tightly as the greenish-gray samples. In addition, three outliers, JL109-3, JL109-4, and JL109-7, have slightly lower Fe concentrations but variable Si concentrations when compared with the other reddish-gray samples. However, these outliers possess a different suite of sedimentary structures and, thus, it appears that low Fe concentration is not a function of any sedimentary structure (and the responsible process), nor is it characteristic of either color suite.

As revealed by Mössbauer spectroscopy, the color difference between greenishgray and reddish-gray siltstone is likely due to the presence of finely dispersed hematite in the latter, most often at the $<20 \mu \mathrm{m}$ scale and concentrations of $<1.10 \mathrm{wt} . \%$ (Table 9). Elemental composition of differently colored samples is indistinguishable with regard to most major elements, and all samples have the same mineralogy for both the framework grains and matrix. Three out of four samples containing hematite are reddish-gray in color. The only non-reddish-gray, hematite-containing sample is JL109-16, a greenishgray sample (5Y 4/1, dark gray). Seven percent of total Fe in this sample occurs in the form of hematite (Table 9), less than half of the lowest hematite content detected in reddish-gray samples (Table 9, in JL109-18, [5YR 3/1, very dark gray]). The JL109-16 thin section displays burrows with reddish-gray rinds in the greenish-gray portion of the sample (Fig. 5C). The reddish-gray rinds may account for the small amount of hematite present in this greenish-gray sample. Samples with hematite do have more $\mathrm{Fe}^{3+}$ than $\mathrm{Fe}^{2+}$ when compared to the samples without hematite (Table 9), but this is a result of hematite being present. However, samples in which hematite is found do not necessarily have 
higher Fe contents. In fact, the lowest Fe concentration among all the samples analyzed with Mössbauer spectroscopy is recorded from a reddish gray sample (Table 7, in JL1093B, [5YR 3/1, very dark gray]). These results indicate that hematite content mostly likely is not the result of contribution from one or more external sources of Fe (e.g., groundwater, hydrothermal fluids, or eolian contribution) added to the sediment. Instead, hematite likely formed from in situ alteration of pre-existing minerals, which is supported by hematite distribution and morphology. Hematite is found most often as coatings on illite and chlorite (Figs.14A, B). Both clay species contain a significant amount of Fe; hence, iron in these clay structures potentially serves as a source for hematite formation. More detailed examination of the structures of these clay minerals may reveal additional evidence for their alteration.

In addition to hematite, Ti oxides and silicates also are found in reddish-gray siltstones. Rutile, titanite, and ilmenite are all strongly colored. Rutile typically is reddish-brown and black, whereas titanite is most often brown, but can be red or black as well (Nesse, 2012). Ilmenite is only black in color (Nesse, 2012). All three minerals are found in the most reddish-brown interval of thin section JL109-16, indicating that they may be responsible for either color enhancement or color variation in reddish-gray samples. Ti-rich minerals were observed in reddish-gray and reddish-brown rocks from other areas by earlier researchers (e.g., Picard, 1965), but have not received much attention in the past 50 years. The current results point to their potential importance in rock coloration, and future studies are required to understand diagenetic genesis of Tirich minerals and their relation with rock color. 
The uniform clay mineralogy of OLP and Bethulie samples, regardless of color, indicates that the greenish-gray colors are primary, while the reddish-gray colors are of diagenetic origin. To date, the only clay minerals present in area of this study, and reported elsewhere in the Karoo (Pace et al., 2009; Gastaldo et al., 2014), are chlorite and illite. In the current study, illite may be in higher abundance as reflected in the height of their primary peaks in XRD spectra (Fig. 12A). Illite is reported to be the most abundant clay mineral in greenish-gray rocks without hematite from other localities (e.g., Maroon Formation, Gore Range, Colorado, from Robb, 1949; Jefferson City Formation, Missouri, from Keller, 1953; Chugwater Formation, Wyoming, Picard, 1965; Juniata and Bald Eagle formations, Pennsylvania, Thompson, 1970). Chlorite also is found in greenishgray rocks and interpreted to be partially responsible for their color (e.g., Thompson, 1970). Therefore, the presence of these two clay minerals likely accounts for a greenishgray color, and slight differences in their relative abundance may be responsible for greenish-gray color variation. Reddish-gray siltstone has the same clay mineralogy as greenish-gray siltstone, indicating that these samples were originally greenish-gray in color as well. As a result of early diagenesis, Fe in some of the clay minerals was altered to hematite coatings on these clay minerals, resulting in the reddish-gray appearance of these rocks.

Chemistry by sedimentary structure groups

Samples in sedimentary structure Group I form four small, separate clusters when plotted as Fe concentration against Si concentration, while samples in Group III form two large clusters that are close to each other (Fig. 18). Because only one sample is assigned to Group II (i.e., does not contain parts that belong to the other groups), Group II samples 
were not included in the scatter plots. Group I samples segregate into four distinct clusters (Fig. 18A) and are separated by gaps in Fe and Si concentrations. The three smaller clusters with lower Fe concentrations are formed by: JL161-4 (left cluster), JL109-3B, JL161-1 (middle cluster), JL117-1, and JL161-7 (right cluster; Fig. 18A). Most of Group III samples plot in a single cluster, with the exception of two samples (JL109-4 and JL161-2; Fig. 18B). The two outliers form a smaller cluster of lower Fe concentration. I postulate that heterogeneity in sedimentary structures and matrix content can account for the segregation of three distinct clusters in Group I plot and two outlier samples in Group III. Samples with low Fe concentration may contain more silt- and clay-sized quartz and feldspars, whereas samples with high Fe concentration may have more clay matrix accompanied by the presence of well-preserved structures with high mud content (mud drapes, mud chips, etc.). Thin sections of JL117-1 and JL161-7 show a greater content of sand- and silt-sized grains, which may explain their higher Si and lower Fe concentrations. The other thin sections and hand samples require more quantitative examination to determine if they contain more quartz and feldspar grains of smaller grain size. Alternatively, data segregation may be the result of the small number of samples in the current study. If additional samples were collected and analyzed, the distinct clusters might coalesce into a single large data cloud. With the currently available data, I cannot conclude whether differences exist in the elemental composition of samples with different structures.

Weathering indices, calculated from data derived from only the clay fractions, indicate that both greenish-gray and reddish-gray siltstones were under the influence of a constant high water table or situated in subaqueous environments (Table 12). Base-loss 
values $(\mathrm{Ca} / \mathrm{Ti}$ and $\mathrm{Na} / \mathrm{Ti}$ used) correlate with the amount of leaching of cations in a soil. The lower the base-loss values, the more leaching has taken place, resulting in reduced concentrations of alkali elements. Values for the Chemical Index of Alteration minus potassium (CIA-K; Sheldon and Tabor, 2009) are indicative of the prevailing climate conditions on a landscape. Following Gastaldo et al. (2014), CIA-K, instead of CIA is employed to eliminate any influence from Mesozoic dolerite intrusions that prevail in the Karoo Basin. CIA-K values lower than 50 are interpreted to correspond to dry conditions in which a low and highly fluctuating water table occurred in soils (Retallack et al., 2003). In contrast, CIA-K values greater than 70 reflect the presence of a constant high water table under wet and humid conditions (Scheffler et al., 2003, 2006).

Samples with Group III structures and high base-loss values potentially could represent floodplain deposits. Leaching, as reflected by high base-loss values, only can occur on the floodplain in a fluvial system. Therefore, Group III samples with the highest base-loss values (JL109-1, 7, 16, JL110-3; Table 12) may have been subaerially exposed. Comparison with base-loss values obtained from well-developed soils will help determine if pedogenesis took place in these samples.

CIA-K values of all samples are indicative of constantly wet conditions. The lowest CIA-K value obtained was 68.38 (from JL161-1), and the highest is over 82 (from JL110-2; Table 2). Because weathering indices only provide an accurate reflection of once prevailing environmental conditions when applied to paleosols, values obtained from samples containing Group I structures are not reflective of the climatic conditions due to their subaqueous depositional environments. Nevertheless, the high values indicative of a high water table support the subaqueous environments for these samples. 
While Groups II and III samples are likely subaqueous deposits despite their higher degrees of bioturbation, it is still possible that these samples represent floodplain deposits. High CIA-K values obtained from these samples would indicate a wet climate prevailing around the time of deposition and early diagenesis if these samples were floodplain deposits.

Few calculations of the Chemical Index of Alteration for Karoo siltstones, all presumed to be paleosols, are published. Retallack et al. (2003, supplemental data) reported CIA-K values below 60 for their Bada (greenish-gray, latest Permian), Karie (weak red, earliest Triassic), Kuta (reddish gray, early Triassic) paleosols. However, recalculation of CIA-K values based on the major element data provided in table 7 in their supplemental data put their reported CIA-K values into question (Gastaldo et al., 2014). The recalculated CIA-K values for all their samples are greater than 57 , except for two paleosol horizons that exhibit high Ca concentrations due to the presence of calcareous nodules. In addition, the grain size of their paleosols range from medium sand to silt (Retallack et al., 2003), generally coarser than samples analyzed in the current study. Coarser-grained sediments commonly have lower CIA values due to greater quartz and feldspar content (Scheffler et al., 2006). Therefore, paleosols of Retallack et al. (2003) would have even higher CIA-K values if the grain size of their paleosols were similar to the samples studied in the current project, which translate to a landscape under wet conditions. In addition, Retallack et al. (2003, fig. 5) reported other geochemical trends in the vertical profile of the three paleosols. However, these "trends" are mostly invariable from horizon to horizon (fig. 5, Retallack et al., 2003), implying that pedogenesis did not greatly alter the geochemistry of the siltstones. This is another aspect 
indicative of a rather constant water table in these sediments. Although Coney et al. (2007) did not calculate CIA-K values, Gastaldo et al. (2014) used data reported by Coney et al. (2007) and calculated CIA-K values $>70$ for their Wapadsberg Pass siltstones. These values are similar to Gastaldo et al.'s (2014) own calculations for paleosols from the Old Wapadsberg Pass area lower in the stratigraphy. CIA-K values $>70$ were interpreted to reflect warm, humid and seasonally wet conditions prior to the vertebrate-defined PTME, as opposed to increasing aridification proposed based on siltstone coloration (Gastaldo et al., 2014). CIA-K values calculated for the current study fall in the same high range and, thus, are indicative of similar climatic conditions for sediments deposited at the same time.

\subsection{Mechanisms for Coloration}

Coloration of Karoo siltstones straddling the vertebrate-defined PTB has been debated as to its utility and significance (Gastaldo and Neveling, 2016; Neveling et al., in press). Geochemical data, along with observations of color and sedimentary structures, reported in the current study enable a thorough examination of previously proposed mechanisms of coloration, and the proposal of a new mechanism that better fits with the observed results.

\section{As a result of aridification}

Previous Karoo Basin studies identified aridification as the mechanism responsible for reddening of original fine-grained sediments (Smith and Ward, 2001; Coney et al., 2007; Smith and Botha-Brink, 2014). Smith and Ward (2001) inferred a rapid shift $(<50,000 \mathrm{yr})$ in climate from wet in the Late Permian to dry in the Early Triassic based on their reported changes in siltstone color, lithology, and fluvial 
architecture across the vertebrate-defined PTB. They proposed that the change from gray (greenish-gray) mudrock in the Upper Permian succession to the conglomeratic sandstone of the Lower Triassic Katberg Formation is associated with a radical change in river morphology (Smith and Ward, 2001). They interpreted the greenish-gray mudrocks at the base of their section to represent floodplain deposits of meandering systems, while the coarse rocks of the Katberg Formation are interpreted as in-channel deposits of braided systems (Smith and Ward, 2001). They linked this change in river morphology to "a general drying of the alluvial plain," which resulted in the "reddening of the flood-plain soils" (Smith and Ward, 2001, p. 1149). This view of reddish-gray mudstone representing aridification generally is accepted in later publications (Coney et al., 2007; Smith and Botha-Brink, 2014). In particular, Coney et al. (2007) state that the color change from green-grey to red-brown is caused by the change in iron oxidation state, an idea also implied by Smith and Botha-Brink (2014) and linked to atmospheric influence.

Smith and Botha-Brink's (2014, p. 105) model identifies an "event bed" that is indicative of "a basin-wide environmental disturbance or climatic event associated with the PTME." This "event bed" (term first proposed by Smith and Ward, 2001) is the only thinly-bedded facies recognized in their model (Smith and Botha-Brink, 2014). It is comprised of "laminated reddish-brown siltstone/mudstone couplets" which "occur at the same position in the facies sequence in all measured sections" and are 3 to $5 \mathrm{~m}$ in thickness (Smith and Botha-Brink, 2014, p. 103). They consider this facies a datum across the basin and representative of the terrestrial expression of the PTME. Smith and Botha-Brink (2014) interpreted this facies to be a result of vegetation-loss-induced weakening of river banks and increased sediment load. The loss of vegetation is 
hypothesized to have been caused by a shift from generally wet to a monsoonal-type climate (Smith and Botha-Brink, 2014). Samples from OLP were collected in previously measured and described stratigraphic sections where interbedded thin, greenish-gray and reddish-gray siltstones occur. In the Fence section, where most samples were collected (Figs. 3, 4), several intervals of thin, reddish-gray siltstone, interbedded with greenishgray siltstone occur over a vertical span of $>30 \mathrm{~m}$. Therefore, not only is Smith and Ward's (2001) “event bed" not a unique interval, but this "3-5-m-thick section" does not occur at the same stratigraphic position in all measured sections. This conclusion supports Gastaldo et al.'s (2009) observations and conclusions at Bethulie. Therefore, an "event bed" indicative of rapidly drying climate is not found basin-wide at the vertebratedefined PTB and cannot be used as evidence for aridification.

High CIA-K values of both greenish-gray and reddish-gray siltstones studied in this project (Table 12), as well as calculated from published data, indicate that humid and wet conditions accompanied by a high water table characterize these deposits. The conclusion that reddening is not linked with aridification is supported by Sheldon (2005) who showed that red Permian paleosols from Cala Viola, Sardinia, are likely a remnant from previous well drained conditions, rather than a function of aridification. Sheldon (2005) concluded that paleosol color was secondary, and the original environment under which these paleosols developed was warm and humid.

Moreover, a high $\mathrm{Fe}^{3+}$ content, alone, cannot account for the reddish color of siltstones, as demonstrated by early studies on rock coloration (e.g., Keller, 1953; Picard, 1965). Many clay minerals, such as illite and chlorite, both of which are abundant in greenish-gray and reddish-gray siltstones, contain $\mathrm{Fe}^{3+}$ and have gray or green colors. 
Therefore, a rock can have very high $\mathrm{Fe}^{3+} / \mathrm{Fe}^{2+}$ but exhibit a greenish color. For example, Picard (1965) reported greenish-gray rocks having a much higher $\mathrm{Fe}^{3+} / \mathrm{Fe}^{2+}$ than some of the reddish-gray rocks studied in the Triassic Chugwater Formation. Robb (1949), Keller (1953), Picard (1965), and Thompson (1970) showed that the presence of illite is a primary factor for green coloration. The results of this study show that reddish color of rocks is linked intimately with hematite abundance but not the concentration of $\mathrm{Fe}^{3+}$.

The formation of hematite may not be related to aridification at all. Mössbauer spectroscopy showed that JL109-3B and JL109-18 (both 5YR 3/1, very dark gray) contain hematite (Table 9). Thin sections of these samples reveal mostly undisturbed, sub-mm-scale bedding with only a few burrows (Figs. 5A, D). Therefore, these primary sedimentary structures indicate that deposition was from bedload or suspension load under very low flow conditions, but never subjected to intense bioturbation associated with extended periods of subaerial exposure. Furthermore, if sediments dried out completely, there should be evidence such as desiccation structures. Primary structures can be preserved by rapid sediment burial, a high water table, or cover by water sufficiently deep to prevent bioturbation. The latter two possibilities are supported by high CIA-K values indicating that the climate was wet enough to maintain moist condition in the siltstones. Therefore, hematite formation would have been influenced primarily by water chemistry, instead of atmospheric conditions.

\section{Eolian input}

Smith and Botha-Brink (2014) suggested that massive maroon mudrocks found above the vertebrate-defined boundary are eolian in origin, accounting for their color through the introduction of airborne hematite. This continues Smith's (1995) early model. 
They consider "thick beds of red uniform textured silt" as evidence to support their eolian model (Smith and Botha-Brink, 2014, p. 105), which are restricted to the lower part of the Lystrosaurus biozone, currently is assigned a Triassic age (although see Gastaldo et al. [2015] who argue for a late Permian age for these fossiliferous lithologies). Observations of thinly-interbedded siltstone occurring through the $30 \mathrm{~m}$ of Lystrosaurus zone in the Fence section at OLP demonstrate that the unit is not massive as reported. Both thinlybedded greenish-gray and reddish gray siltstone occur, often interbedded on a dm to $\mathrm{mm}$ scale. Such features are not indicative of eolian deposits (Gastaldo and Neveling, 2016), and an eolian depositional mechanism is not supported by the results of the current study, either.

Additional lines of evidence against an eolian origin for the reddish-gray siltstones found in the Lystrosaurus biozone come from hematite morphology and distribution. Finely dispersed hematite occurs as coatings on only some of the clay mineral plates (Figs. 14A, B). If the reddish-gray color resulted from eolian-derived hematite, this mineral should occur as small detrital grains more evenly distributed throughout the siltstone matrix. However, the presence of hematite as coatings on clay minerals indicates an in situ generation of the oxide, rather than a primary detrital origin.

\section{Baking effect and hydrothermal alteration}

Due to the prevalence of Mesozoic dolerite intrusions, many authors have considered contact metamorphism and metasomatism to be a source of siltstone coloration (Retallack et al., 2003; Coney et al., 2007; Smith and Botha-Brink, 2014). Smith and Botha-Brink (2014, p. 105) found that "the baking effects along the margins of dolerite intrusions locally change the mudrock colour in this facies [the lower Triassic 
massive maroon mudrocks] to light grey (5Y 7/2 [a very pale olive gray])." This thermally altered color is not found in any of the samples examined in the current study because samples were not collected near intrusive bodies. Retallack et al. (2003) state that dolerite dikes only affect the coloration of rocks within a distance equivalent to twice the dike width, indicating that thermal influence is rather localized. However, hydrothermal fluids can travel much farther through permeable rock bodies and fractures, affecting sediments and rocks in a much larger area. Because rocks only are exposed in erosional gullies at the Old Lootsberg Pass collection sites, it was difficult to make precise lateral correlations that would enable identification of intervals with laterally varying color, which potentially resulted from hydrothermal alteration. This is not the case at Bethulie where the same bed can be traced laterally for several hundred meters (Battifarano et al., 2015). Therefore, the possibility that some of the colors observed in the OLP samples may be the result of metasomatism cannot be eliminated. More detailed field observations are required to identify colors and their distance from an intrusive body that potentially may be the result of metasomatic alteration.

\section{Interaction with in-channel water or ground water}

Early studies on rock coloration revealed that both greenish- and reddish-gray colorations can be either primary or secondary (e.g., Picard, 1965; Thompson, 1970). Reddish-gray color can be due to detrital hematite grains transported from elsewhere (commonly erosion of red soils; e.g., Sheldon, 2005), in situ hematite-forming reactions, or direct precipitation from pore fluids (Picard, 1965). Greenish-gray color is typically due to the presence of specific clay minerals (e.g., illite and chlorite), which can be either detrital or formed after deposition from alteration of other clay species (Thompson, 1970; 
Weibel and Friis, 2004). In the case of the OLP and Bethulie samples, finely dispersed hematite most commonly occurs as coatings on clay plates, indicating that hematite was generated after the clay minerals formed. Whether illite and chlorite found in the Karoo samples are secondary cannot be determined based on available data. But, their presence as the only recognized clay species in latest Permian and earliest Triassic siltstones, to date (Pace et al., 2009; Gastaldo et al., 2014), is evidence of their widespread occurrence. Nevertheless, the presence of hematite coatings on both clay species indicates that the samples were initially all greenish-gray, and later formation of hematite is responsible for a change in coloration to reddish gray.

The uneven distribution of hematite coatings in the samples and the relationship between greenish-gray and reddish-gray beds indicate in situ genesis soon after deposition. Previous studies of other red beds reveal that hematite is rather evenly distributed throughout the rock fabrics, either coating most/all framework grains or filling most/all pore spaces (e.g., Robb, 1949; Picard, 1970). Based on the physical relationship among hematite, framework grains, and cements in the rocks, Picard (1965) and Weibel and Friis (2004) proposed that hematite formation may have been initiated soon after deposition and continued until late-stage diagenesis. The samples analyzed in the current study are different from these case studies because hematite is almost exclusively encountered as coatings on clay minerals (Figs. 14A, B). This relationship indicates that hematite formation is intimately linked with these clay minerals, either via direct alteration from the clay minerals, or preferred nucleation on the clay surfaces from external Fe sources. Because reddish-gray samples do not contain significantly higher $\mathrm{Fe}$ contents than the greenish-gray samples, an external source of Fe preferably precipitating 
as hematite on clay is discounted. A similar conclusion was drawn by Bensing et al. (2005) who also found that detrital illite and chlorite clays are likely the source of iron for hematite generation in the Abo Formation, New Mexico. In addition, the presence of thin, interlaminated greenish-gray and reddish-gray siltstones (e.g., thin section JL109-18; Fig. 5D) implies that hematite generation may have been completed before the next bed of sediment was deposited. Hence, hematite may have formed in the narrow time window between settlement of suspension load and influx of the next pulse of sediment in response to a change in water chemistry.

Formation of hematite in the Karoo samples is likely a result of the interaction between clay minerals and the surface water geochemistry. The presence of primary structures and high CIA-K values calculated from major element concentrations both indicate subaqueous or wet environments for the sediments. As such, any influence of atmospheric conditions was mostly likely insulated from the sediment-water interface and should not have had any perceptible effect on hematite formation. Therefore, hematite coatings on only some of the clay minerals is likely due to the interaction of the clay mineral grains with aqueous geochemistry. One piece of evidence for hematite formation at the sediment-water interface comes from petrographic observation of JL161-1 thin section (Fig. 7F). Here, what appear to be organic-rich mud drapes at first glance are, in fact, made of oxide grains with indistinct grain boundaries (Fig. 7F). The unclearly defined edges can be taken as evidence for in situ, secondary generation of the oxide grains. Factors that can influence alteration of clay minerals to hematite in such environments include the Eh and $\mathrm{pH}$ of the water (Keller, 1953), and possibly the composition of the dissolved load. 


\section{Other possibilities}

Several studies have suggested that ferric iron (oxy)hydroxides associated with clay minerals act as a source for iron in hematite formation (McBride, 1974; Braunagel and Stanley, 1977; Bensing et al., 2005). Ferric iron hydroxides often are found adhered to clay plates that were derived from better-drained soils, and these soils generally develop in warm and humid climates (van Houten, 1972, 1973). Dehydration and aging of these hydroxides result in hematite formation, and this process can occur diagenetically without a restricted set of geochemical conditions (Braunagel and Stanley, 1977). If hematite in the Karoo siltstones formed through this process, the greenish-gray and reddish-gray colors would reflect differences in original depositional concentration of ferric iron hydroxides. This would imply that either the source of clay minerals in different colored siltstones would have been different, or the same source was under the influence of a radically different climate. Different source regions for the clay fraction of greenish-gray and reddish-gray siltstones would require that vastly different soils developed in completely different climates to be in close proximity to each other to produce the alternating pattern of $\mathrm{cm}$ - to $\mathrm{mm}$-scale greenish- and reddish-gray beds. If the different colors were derived from the same source region, the alternating pattern of then would imply rapid shifts between different parts of a climate cycle to produce each uniquely colored sediment. Because climate cycles are controlled by one or more Milankovitch cycles, such rapid climatic shifts would not be possible unless the sedimentation rate was extremely low.

In addition to hematite formation via interaction with channel water, burrowing may produce favorable conditions for its formation on a very local scale. As seen in the 
thin section of JL109-16 (Fig. 5C), burrows in greenish-gray siltstone can have reddishgray rinds. Hematite rinds could have resulted from organismal respiration, organic matter decay, or, once again, interaction with water introduced into the sediment by burrowing activities. Alternatively, oxidation of iron in burrow walls could be related to the secretions and/or excretions of the burrowing organism, producing favorable conditions for alternation of clay minerals to hematite on a microscopic scale. 


\section{SUMMARY}

Karoo siltstones have been used for decades as evidence to support a climatechange model for the terrestrial PTME (Ward et al., 2000; Smith and Ward, 2001; Smith and Botha-Brink, 2014). All siltstone deposits in the Beaufort Group are presumed to be floodplain deposits and paleosols (Smith, 1980, 1900, 1993, 1995), and their coloration is thought to be a function of iron oxidation state controlled by atmospheric conditions. However, such extensive use of the physical features of these rocks as climate indicators has not been tested either petrographically, mineralogically, or geochemically.

This study provides the first thorough examination of any Beaufort Group siltstone, the basis for its coloration, and its relation with environmental conditions at the time of deposition. Questions proposed before the onset of the study, and those evolved as the study progressed, include:

1. Do Beaufort Group siltstones all represent floodplain deposits?

2. Are greenish- and reddish-gray siltstones chemically and/or mineralogically different?

3. Is the coloration of these siltstones a function of $\mathrm{Fe}^{2+} / \mathrm{Fe}^{3+}$ ?

4. Does the coloration of these siltstones reflect climatic conditions at the time of deposition?

5. In particular, are reddish-gray siltstones above the vertebrate-defined PTB eolian in origin?

6. Does the color change in siltstones reflect a rapid climate change from wet to dry conditions before the terrestrial PTME?

7. How did hematite form in the reddish-gray siltstones? 
Results from this study help answer these questions and propose new interpretations of Karoo siltstones.

1. Beaufort Group siltstones do not all represent floodplain deposits. The presence of undisturbed to minimally disturbed primary structures, such as crossbeds and finingup cycles, in samples invalidate the interpretation that all Beaufort Group siltstones were deposited on the floodplain. In fact, most samples evaluated in the current study contain undisturbed primary structures throughout, or in a portion of, the samples. These features are indicative of deposition under flowing water conditions, without extended periods of subaerial exposure. Bioturbation in the samples also may have occurred under flowing water, as low sediment load or discharge velocities did not prevent biological activities in subaqueous fluvial environment in the Permian.

2. Major element composition of the two color suites are coincident and the only clay minerals present are illite and chlorite. The significant difference between greenishand reddish-gray siltstone is that the latter contains very low concentration ( $\leq 1 \mathrm{wt} . \%)$ of hematite in the form of coatings on some clay mineral grains.

3. Siltstone coloration is associated with the presence/absence of hematite coatings on clay minerals, not the proportion of $\mathrm{Fe}^{2+} / \mathrm{Fe}^{3+}$, per se. Greenish- and reddish-gray samples do not differ in total Fe concentration. Therefore, the mere abundance of Fe does not account for either color. Because hematite is a ferric iron oxide, the presence of this mineral does result in a lower $\mathrm{Fe}^{2+} / \mathrm{Fe}^{3+}$ in the reddish-gray samples. However, the clay minerals found in the samples, illite and chlorite, both can contain ferric iron in their crystal structure. Greenish-gray siltstone with a much higher ferric $\mathrm{Fe}$ concentration than reddish-gray siltstone has been reported by early researchers (e.g., 
Picard, 1965). Therefore, the reddish-gray coloration is not due to the relative abundance of oxidized form of $\mathrm{Fe}$, but the presence of hematite coatings on clay minerals. Illite and chlorite clasts not coated with hematite can account for the greenish-gray color. The physical relationship between hematite and clay minerals shows that reddish-gray color is secondary. In addition, the presence of Ti-rich minerals (titanite, ilmenite, and rutile) may explain the color variation observed in the reddish-gray siltstones.

4. Coloration does not reflect climatic conditions at the time of silt deposition. Sediments on floodplains are exposed to atmospheric conditions down to the level of the water table and, therefore, their geochemistry is constantly modified by them. However, these sediments are subjected to intense bioturbation, which would destroy any primary sedimentary structure that was present over time and homogenize the sediment. Undisturbed primary sedimentary structures preserved in most of the samples indicate that the sediments were protected from pedogenic processes by a high water table, high flow rate, or rapid burial resulting from a high sedimentation rate. High CIA-K values for all samples are indicative of a constantly high water table. Reddish-gray siltstones include both samples with undisturbed primary structures and samples that are completely bioturbated, but yielded high CIA-K values. Therefore, there are no data indicating that the formation of hematite and the reddish-gray coloration can be linked to a dry climate. Moreover, neither color is found to be exclusively associated with a single type of environment or a single set of similar environments. Hence, specific climatic conditions cannot be inferred from the color of siltstone. 
5. Field observations, sedimentary structures, and hematite morphology evidence against an eolian origin of the reddish-gray siltstone facies. Smith and Botha-Brink (2014) report that the massive architecture of the reddish-gray siltstones found above the vertebrate-defined PTB is evidence for eolian deposits. However, intervals from which the OLP Fence section samples were collected contain both greenish- and reddish-gray siltstones, often interbedded on a $\mathrm{dm}$ to $\mathrm{mm}$ scale. Undisturbed primary structures cannot be maintained if the sediments were deposited by wind on the floodplain, where intense bioturbation would occur following their deposition. If the reddish-gray coloration originates from micron-sized airborne hematite, this mineral should occur as detrital grains randomly distributed throughout the rock as a function of sedimentation. However, hematite was primarily found as coatings on some of the clay mineral grains, indicative of in situ generation of the oxide.

6. A rapid climate change from wet to dry conditions cannot be inferred from siltstone color. Following the logic presented above, a subaqueous depositional environment for most of the samples, and high CIA-K values yielded by all samples regardless of their sedimentary structures, are indicative of a constantly high water table, which is not possible under a dry climate. Reddish-gray coloration results neither from interaction with atmospheric oxygen in a dry environment, nor from dust deposited by cyclones moving across dry landscape. The overlap in major element concentrations of the two colored siltstones also is not indicative of formation under vastly different environments.

7. Because most samples likely represent subaqueous deposits, hematite formation most likely is associated with temporal changes in water chemistry. Hematite coatings on 
green-clay minerals indicate that all siltstones were originally greenish-gray, and hematite coatings formed after deposition in some sediments, resulting in the reddishgray color. Interlamination of greenish-gray and reddish-gray siltstones (e.g., thin section JL109-18; Fig. 5D) implies that hematite probably formed rapidly between settlement of suspension load and influx of the next pulse of sediment. Eh and $\mathrm{pH}$ of the channel water are the factors most likely influencing hematite formation. 


\section{LITERATURE CITED}

Battifarano, O.K., Churchill, A.N., Gastaldo, R.A., Neveling, J., Geissman, J.W., 2015, Lithostratigraphy and lateral variation in vertebrate biostratigraphy near the PermianTriassic Boundary at Bethulie, South Africa: Geological Society of America Abstracts with Programs, vol. 47, no. 7, p. 570.

Bensing, J.P., Mozley, P.S., and Bunbar, N.W., 2005, Importance of clay in iron transport and sediment reddening: evidence from reduction features of the Abo Formation, New Mexico, U.S.A.: Journal of Sedimentary Research, v. 75, p. 562-571.

Benton, M.J., and Newell, A.J., 2014, Impact of global warming on Permo-Triassic terrestrial ecosystems: Gondwana Research, v. 25, p. 1308-1337.

Boggs, Jr., S., 2009, Petrology of Sedimentary Rocks, 2nd ed.: Cambridge University Press, Cambridge, $600 \mathrm{p}$.

Bordy, E., Sztanó, O., Rubidge, B.S., and Bumby, A., 2011, Early Triassic vertebrate burrows from the Katberg Formation of the south-western Karoo Basin, South Africa: Lethaia, v. 44, p. 33-45.

Braunagel, L.H., and Stanley, K.O., 1977, Origin of variegated redbeds in the Cathedral Bluffs Tongue of the Wasatch Formation (Eocene), Wyoming: Journal of Sedimentary Petrology, v. 47, no. 3, p. 1201-1219.

Burgess, S.D., Bowring, S., and Shen., S., 2014, High-precision timeline for Earth's most severe extinction: PNAS, v. 111, p. 3316-3321.

Coney, L. Reimold, W.U., Hancox, J., Mader, D., Koeberl, C., McDonald, I., Struck, U., Vajda, V., and Kamo, S.L., 2007, Geochemical and mineralogical investigation of the Permian-Triassic boundary in the continental realm of the southern Karoo Basin, South Africa: Paleoworld, v. 16, 67-104.

Day, M.O., Ramezani, J., Bowring, S.A., Sadler, P.M., Erwin, D.H., Abdala, F., and Rubidge, B.S., 2015, When and how did the terrestrial mid-Permian mass extinction occur? Evidence from the tetrapod record of the Karoo Basin, South Africa: Proceedings Royal Society B, v. 282, 20150834.

De Kock, M.O., and Kirschvink, J.L., 2004, Paleomagnetic Constraints on the PermianTriassic Boundary in Terrestrial Strata of the Karoo Supergroup, South Africa: Implications for Causes of the End-Permian Extinction Event: Gondwana Research, v. 7, no. 1, p. 175-183.

DiMichele, W.A., and Gastaldo, R.A., Plant Paleoecology in Deep Time, Annals of the Missouri Botanical Garden, v. 95, no. 1, p. 144-198.

Droser, M.L. and Bottjer, D.J., 1986, A semiquantitative field classification of ichnofabric: Journal of Sedimentary Research, v. 56, p. 558-559. doi:10.1306/212f89c2-2b24-11d7-8648000102c1865d

Erwin, D.H., 2006, Extinction: how life on earth nearly ended 250 million years ago: Princeton University Press, Princeton, N.J., 296 p.

Gastaldo, R.A., and Rolerson, M.W., 2008, Katbergia gen. Nov., a new trace fossil from Upper Permian and Lower Triassic rocks of the Karoo Basin: implications for palaeoenvironmental conditions at the P/Tr Extinction event: Palaeontology, v. 51, no. 1, p. 215-229.

Gastaldo, R.A., and Demko, T.M., 2011, The relationship between continental landscape evolution and the plant-fossil record: Long term hydrology controls the plant fossil record: in Allison, P.A., and Bottjer, D.J., eds., Taphonomy, Second 
Edition: Processes and Bias Through Time: Springer Netherlands, Netherlands, Topics in Geobiology, v. 32, p. 24-286.

Gastaldo, R.A., and Neveling, J., 2012, The terrestrial Permian-Triassic boundary event is a nonevent: Reply: Geology, v. 40, p. e257, doi:10.1130/G32975Y.1.

Gastaldo, R.A., and Neveling, J., 2016, Comment on "Anatomy of a mass extinction: Sedimentological and taphonomic evidence for drought-induced die-offs at the Permo-Triassic boundary in the main Karoo Basin, South Africa" by R.M.H. Smith and J. Botha-Brink, Palaeogeography, Palaeoclimatology, Palaeoecology, v. 396, p. 99-118.

Gastaldo, R.A., Neveling, J., Clark, K., and Newbury, S.S., 2009, The terrestrial Permian-Triassic boundary event bed is a nonevent: Geology, v. 37, no. 3, p. 199202.

Gastaldo, R.A., Knight, C.L., Neveling, J., and Tabor, N.J., 2014, Latest Permian paleosols from Wapadsberg Pass, South Africa: Implications for Changhsingian climate: Geological Society of America Bulletin, v. 126, no. 5/6, p. 665-679.

Gastaldo, R.A., Kamo, S.L., Neveling, J., Geissman, J.W., Bamford, M., and Looy, C.V., 2015, Is the vertebrate-defined Permian-Triassic boundary in the Karoo Basin, South Africa, the terrestrial expression of the end-Permian marine event?: Geology, doi:10.1130/G37040.1

Golosov, V., Belyaev, V., and Walling, D.E., 2004, Sediment Transfer Through the Fluvial System: Proceedings of the International Symposium Held at Moscow, Russia, from 2 to 6 August, 2004: IAHS Proceedings and Reports, v. 288, 498 p.

Johnson, M.R., van Vuuren, C.J., Visser, J.N.J., Cole, D.I., Wickens H.de V., Christie, A.D.M., Roberts, D.L., and Brandl, G., 2006, Sedimentary rocks of the Karoo Supergroup, in Johnson, M.R., Anhaeusser, C.R., and Thomas, R.J., eds., The Geology of South Africa: the Geological Society of South Africa, Johannesburg, and the Council for Geoscience, Pretoria, p. 461-499.

Keller, W.D., 1953, Illite and montmorillonite in green sedimentary rocks: Journal of Sedimentary Petrology, v. 23, no. 1, p. 3-9.

McBride, E.F., 1974, Significance of color in red, green, purple, olive, brown and gray beds of Difunta Group, northeastern Mexico: Journal of Sedimentary Petrology, v. 44, no. 3, p. 760-773.

Neveling, J., Gastaldo, R.A., Kamo, S.L., Geissman, J.W., Looy, C.V., and Bamford, M.K., In Press, A Review of Stratigraphic, Geochemical, and Paleontologic Correlations Data of the Terrestrial end-Permian record in the Karoo Basin, South Africa: in de Wit, M., and Linol, B., eds., The Origin and Evolution of the Cape Mountains and Karoo Basin: Springer Publishing.

Nesse, W.D., 2012, Introduction to Mineralogy, 2nd ed.: Oxford University Press, New York, N.Y., $480 \mathrm{p}$.

Pace, D.W., Gastaldo, R.A., and Neveling, J., 2009, Early Triassic aggradational and degradational landscapes of the Karoo Basin and evidence for climate oscillation following the P-Tr event: Journal of Sedimentary Research, v. 79, p. 316-331.

Payne, J.L., and Clapham, M.E., 2012, End-Permian Mass Extinction in the oceans: an ancient analog for the twenty-first century?: Annual Review of Earth and Planetary Sciences, v. 40, p. 89-111. 
Picard, M.D., 1965, Iron oxides and fine-grained rocks of Red Peak and Crow Mountain sandstone members, Chugwater (Triassic) Formation, Wyoming: Journal of Sedimentary Petrology, v. 35, no. 2, p. 464-479.

Pollastro, R.M., 1982, A recommended Procedure for the preparation of oriented claymineral specimens for X-ray diffraction analysis: modifications to Drever's filtermembrane peel technique: United States Department of the Interior Geological Survey, Open-File Report 82-71.

Retallack, G.J., 2001, Soils of the Past: An Introduction to Paleopedology, Second Edition: Malden, Massachusetts, Blackwell Science, 404 pp.

Retallack, G.J., Smith, R.M.H., and Ward, P.D., 2003, Vertebrate extinction across Permian-Triassic boundary in Karoo Basin, South Africa: Geological Society of America Bulletin, v. 115, p. 1133-1152.

Rey, K., Amiot, R., Fourel, F., Rigaudier, T., Abdala, F., Day, M.O., Fernandez, V., Fluteau., F., France-lanord, C., Rubidge, B.S., Smith., R.M., Viglietti., P.A., Zipfel, B., and Lécuyer, C., 2015, Global climate perturbations during the PermoTriassic mass extinctions recorded by continental tetrapods from South Africa, GR-01523. Doi 10.1016/j.gr.2015.09.008

Robb, G.L., 1949, Red bed coloration, Journal of Sedimentary Petrology, v. 19, no. 3, p. 99-103.

Rubidge, B.S., Erwin, D.H., Ramezani, J., Bowring, S.A., and de Klerk, W.J., 2013, High-precision temporal calibration of Late Permian vertebrate biostratigraphy: $\mathrm{U}-\mathrm{Pb}$ zircon constraints from the Karoo Supergroup, South Africa: Geology, v. 41, no. 3, p. 363-366.

Scheffler, K., Hoernes, S., and Schwark, L., 2003, Global changes during Carboniferous-Permian glaciation of Gondwana: Linking polar and equatorial climate evolution by geochemical proxies: Geology, v. 31, p. 650-608.

Scheffler, K., Buehmann, D., and Schwark, L., 2006, Analysis of late Palaeozoic glacial to postglacial sedimentary successions in South Africa by geochemical proxies Response to climate evolution and sedimentary environment: Palaeogeography, Palaeoclimatology, Palaeoecology, v. 240, p. 184-203.

Sheldon, N.D., 2005, Do red beds indicate paleoclimatic conditions?: A Permian case study, Palaeogeography, Palaeoclimatology, Palaeoecology, v. 228, p. 305-319.

Sheldon, N.D., and Tabor, N.J, 2009, Quantitative paleoenvironmental and paleoclimatic reconstruction using paleosols: Earth-Science Reviews, v. 95, p. 1-52.

Smith, R.M.H., 1980, The lithology, sedimentology and taphonomy of flood-plain deposits of the Lower Beaufort (Adelaide Subgroup) strata near Beaufort West: Transactions of the Geological Society of South Africa, v. 83, p. 399-413.

Smith, R.M.H., 1990, Alluvial paleosols and pedofacies sequences in the Permian Lower Beaufort of the southwestern Karoo Basin, South Africa: Journal of Sedimentary Petrology, v. 60, no. 2, p. 258-276.

Smith, R.M.H., 1993, Sedimentology and ichnology of floodplain paleofacies in the Beaufort Group (Late Permian), Karoo Sequence, South Africa: Palaios, v. 8 p. 339-357.

Smith, R.M.H., 1995, Changing fluvial environments across the Permian-Triassic boundary in the Karoo Basin, South Africa and possible causes of tetrapod 
extinctions: Palaeogeography, Palaeoclimatology, Palaeoecology, v. 117, p. 81104.

Smith, R.M.H., and Botha, J., 2005, The recovery of terrestrial vertebrate diversity in the South African Karoo Basin after the end-Permian Extinction: Compte Rendu Palevol, v. 4, p. 555-568.

Smith, R.M.H., and Botha-Brink, J., 2014, Anatomy of a mass extinction: Sedimentological and taphonomic evidence for drought-induced die-offs at the Permo-Triassic boundary in the main Karoo Basin, South Africa: Palaeogeography, Palaeoclimatology, Palaeoecology, v. 396, p. 99-118.

Smith, R.M.H., Eriksson, P.G., and Botha, W.J., 1993, A review of the stratigraphy and sedimentary environments of the Karoo-aged basins of Southern Africa: Journal of African Earth Sciences, v. 16, p. 143-169.

Smith, R.M.H, and Ward, P.D., 2001, Pattern of vertebrate extinctions across an event bed at the Permian-Triassic boundary in the Karoo Basin of South Africa: Geology, v. 29, no. 12, p. 1147-1150.

Thompson, A.M., 1970, Geochemistry of color genesis in red-bed sequence, Juniata and Bald Eagle formations, Pennsylvania: Journal of Sedimentary Petrology, v. 40, no. 2, p. 599-615.

Turner, B.R., 1978, Sedimentary patterns of uranium mineralisation in the Beaufort Group of the southern Karoo (Gondwana) Basin, South Africa: in Miall, A.D., Ed., Fluvial Sedimentology, Canadian Society of Petroleum Geologists, Calgary, p. 831-848.

Van Houten, F.B., 1972, Iron and clay in tropical savanna alluvium, northern Colombia: A Contribution to the origin of red beds: Geological Society of America Bulletin, v. 83 , p. $2761-2772$.

Van Houten, F.B., 1973, Origin of red beds, a review: 1961-1972: Annual Review Earth and Planetary Sciences, v. 1, p. 39-61.

Viglietti, P.A., Smith, R.M.H., Angielczyk, K.D., Kammerer, C.F., Fröbisch, J., and Rubidge, B.S., 2016, The Daptocephalus Assemblage Zone (Lopingian), South Africa: A proposed biostratigraphy based on a new compilation of stratigraphic ranges: Journal of African Earth Sciences, v.113, p. 153-164.

Ward, P.D., Montgomery, D.R., and Smith, R.M.H., 2000, Altered river morphology in South Africa related to the Permian-Triassic extinction: Science, v. 289, p. 17401743.

Ward, P.D., Botha, J., Buick, R., De Kock, M.O., Erwin, D.H., Garrison, G.H., Kirschvink, J.L., and Smith, R., 2005, Abrupt and gradual extinction among Late Permian land vertebrates in the Karoo Basin, South Africa: Science, v. 307, p. 709-714.

Weibel R., and Friis, H., 2004, Opaque minerals as keys for distinguishing oxidising and reducing diagenetic conditions in the Lower Triassic Bunter Sandstone, North German Basin: Sedimentary Geology, v. 169, p. 129-149. 


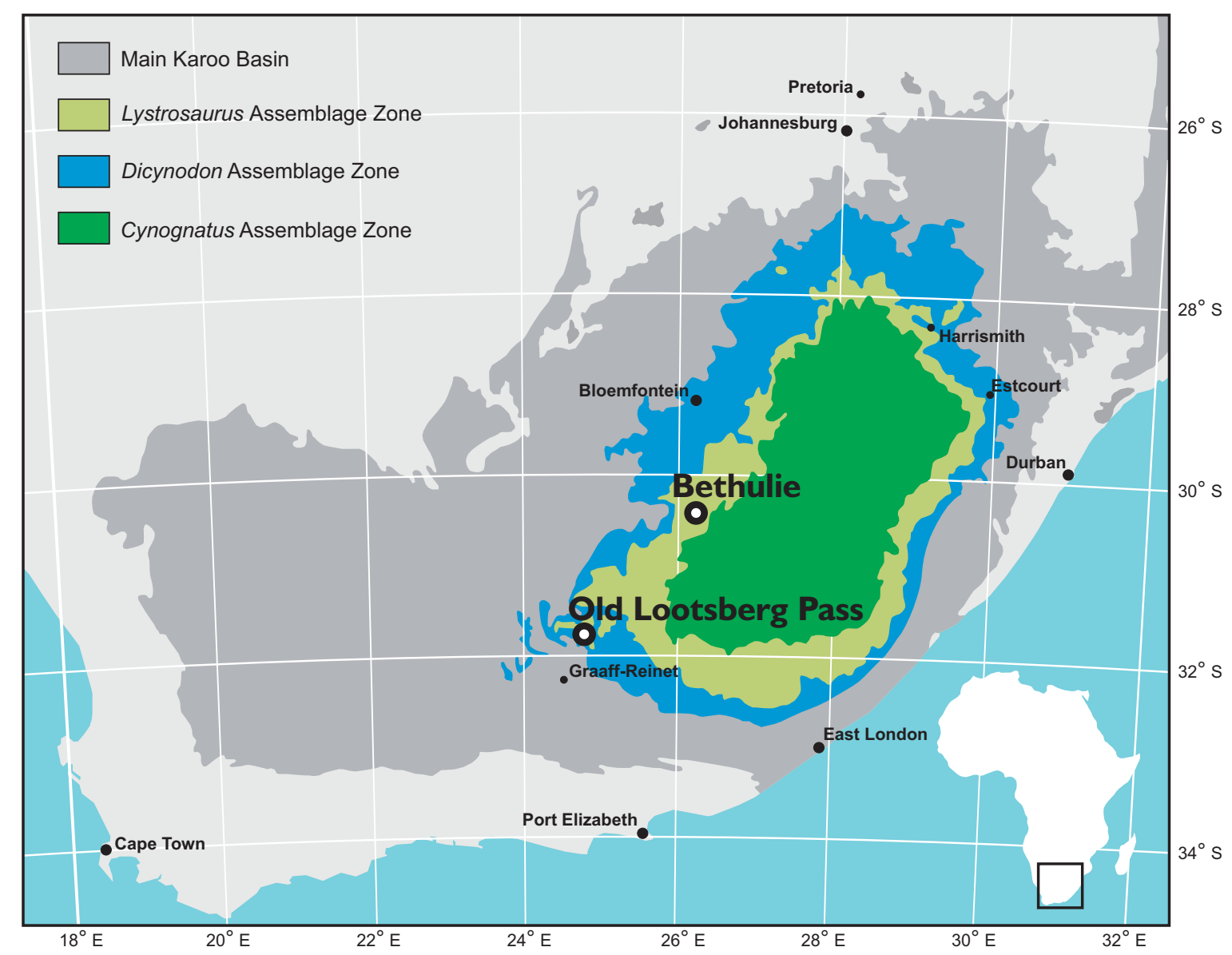

Figure 1. Generalized map showing the distribution of the Karoo Basin (dark gray polygon) rocks, the location of field sites, the Dicynodon Assemblage Zone (blue; renamed Daptocephalus by Viglietti et al., 2016) and the Lystrosaurus Assemblage Zone (green). The terrestrial response to the end-Permian event is reported to have occurred across the boundary between the two assemblage zones (the biozone boundary). The Cynognatus Assemblage Zone (dark green) shows the distribution of surface exposures of Lystrosaurus Assemblage Zone rocks. 


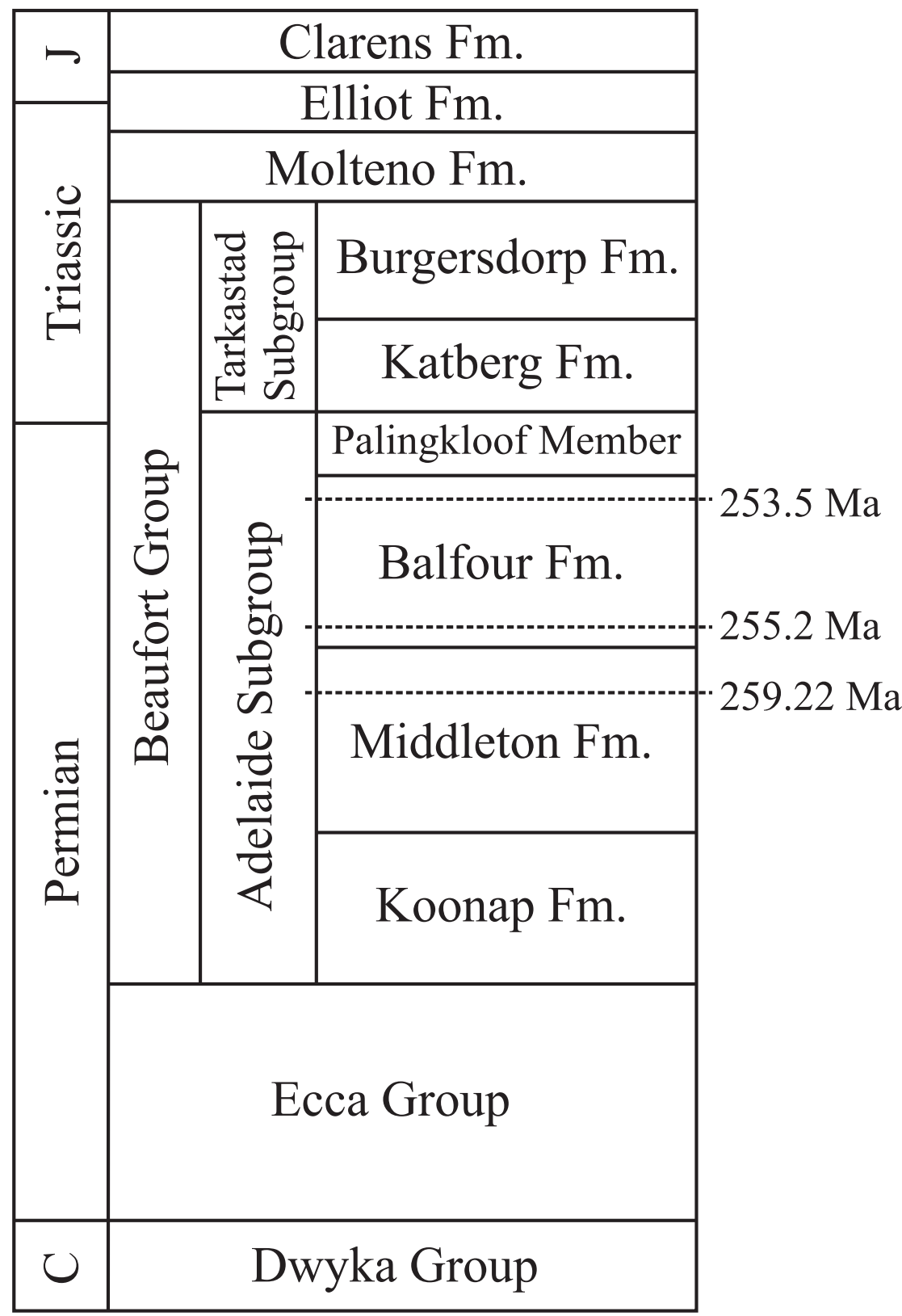

Figure 2. Simplified stratigraphy of the Karoo Supergroup, modified after Johnson et al. (2006). Temporal correlation after Rubidge et al. (2013). The vertebrate-defined PTB is reported in the Palingkloof Member of the Balfour Formation (Ward et al., 2005; Smith and Botha-Brink, 2014). C: Carboniferous. J: Jurassic. Fm: Formation. Not to scale. 


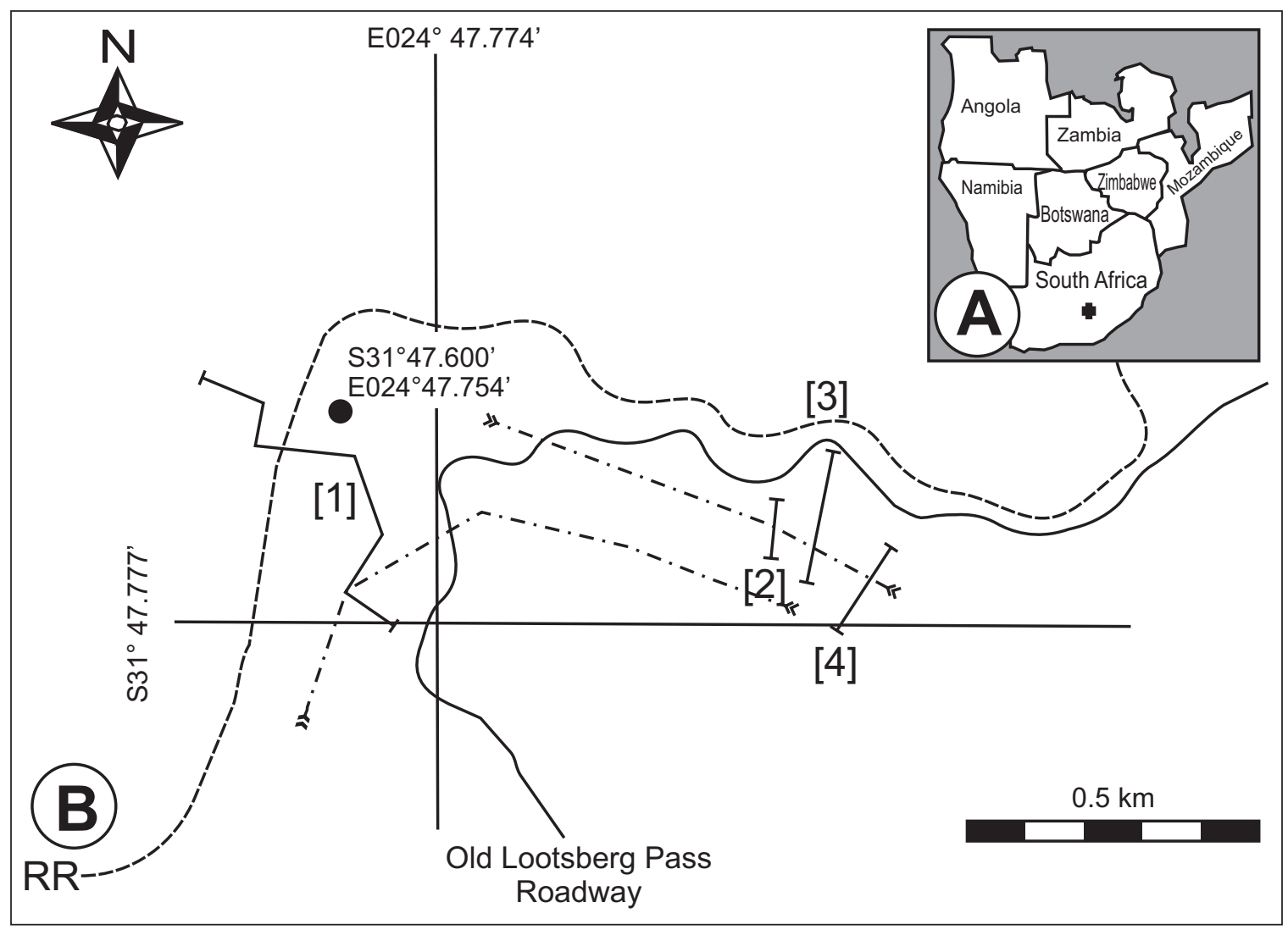

Figure 3. Location maps. (A) Location of study site (OLP) in southern Africa plotted as a cross. (B) Positions of measured stratigraphic sections at OLP from which siltstone samples were collected. Capped lines are transects over which stratigraphic sections were measured. Numbered sections are: (1) Woody Gully section; (2) Waterworn section; (3) Fence section; (4) East section. RR: railroad. The black circle below the railroad marks the GPS coordinates of Ward et al.'s (2000) stratigraphic section reported to span the PTB. Scale bar $=0.5 \mathrm{~km}$. 


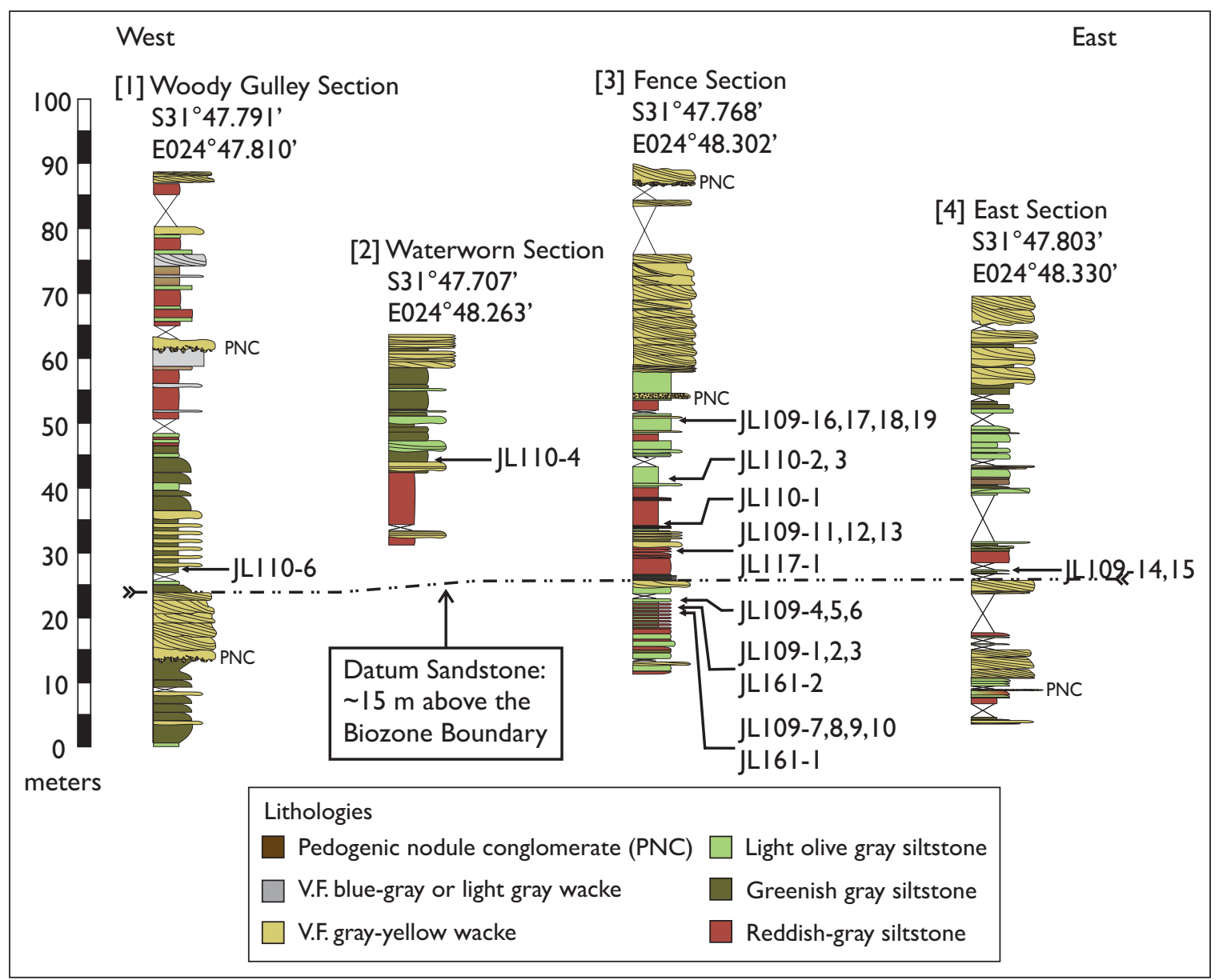

Figure 4. Collection sites of OLP samples in a stratigraphic framework. Sections correspond to transects shown in Figure 3. Dashed-and-dotted line is the upper contact of the sandstone used by Gastaldo et al. (2015) as a datum on which local correlation is made. Scale in $5 \mathrm{~m}$ intervals. 


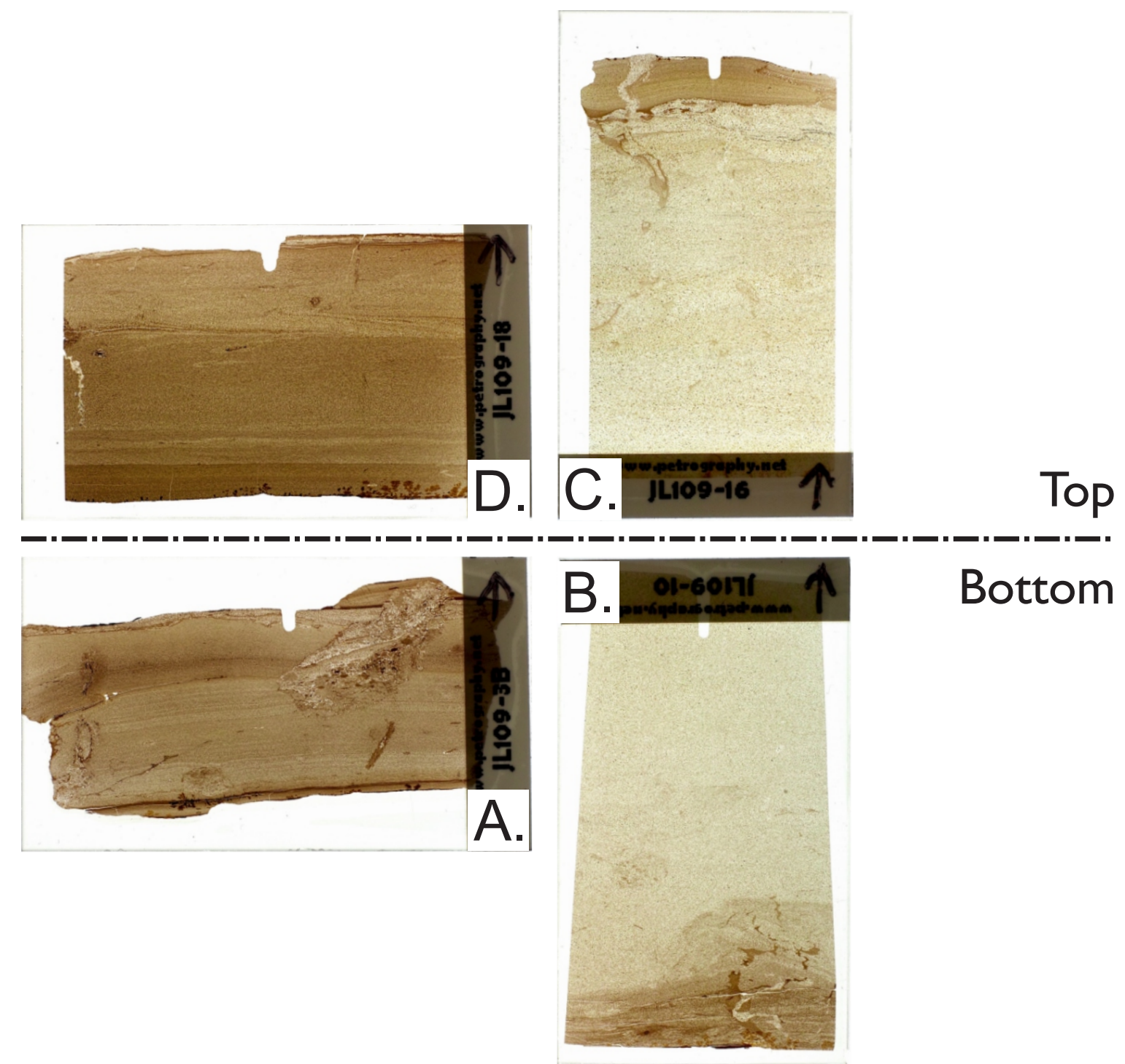

Figure 5. Photomicrographs of thin sections of the OLP samples sent out for Mössbauer spectroscopy in August 2015. All samples were collected in the Fence [3] section (see Figs. 3, 4). Thin sections are in stratigraphic up orientation. (A) JL109-3B, thinly laminated reddish-gray (5YR 3/1) siltstone. (B) JL109-10, greenish-gray (5Y 4/1) siltstone with thin reddish-gray beds at the bottom. (C) JL109-16, greenish-gray (5Y 4/1) siltstone with thin reddish-gray beds at the top. (D) JL109-18, thinly laminated reddishgray (5YR 3/1) siltstone. (A) and (B) are from the bottom of the section; (B) and (D) are from the top of the section. 

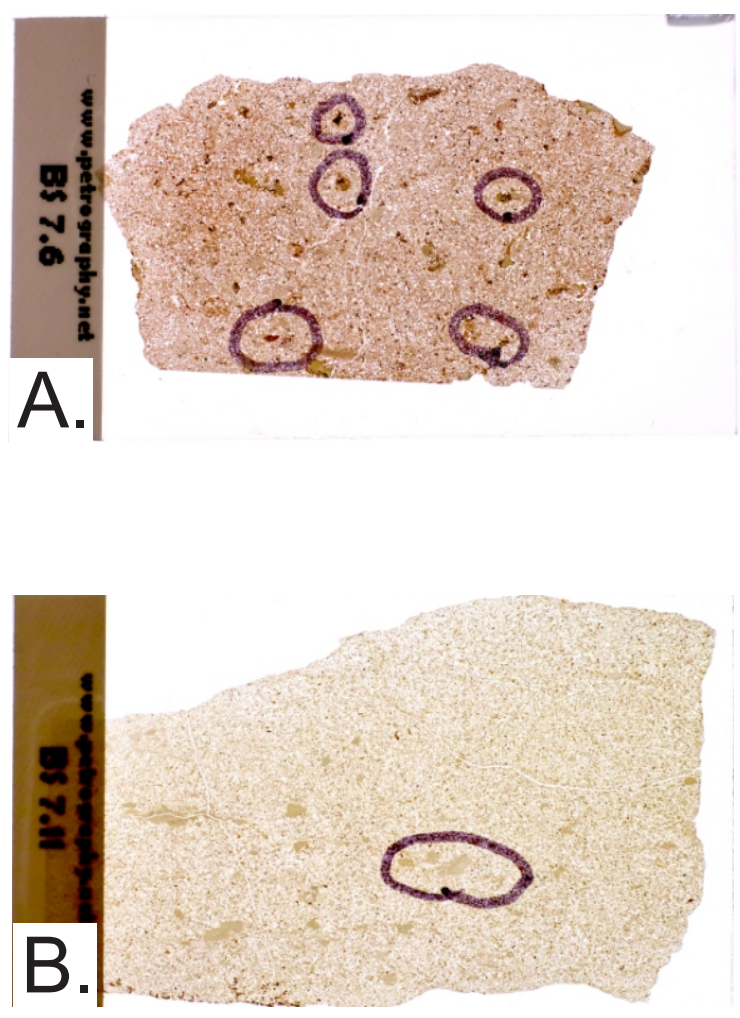

Figure 6. Photomicrographs of thin sections of the Bethulie samples sent out for Mössbauer spectroscopy in August 2015. Thin sections are in stratigraphic up orientation. (A) B.S.7.6, reddish-gray (5YR 4/1) sandy siltstone, collected from the vertebrate-defined PTB interval figured by Smith and Botha-Brink (2014; fig. 4). (B) B.S.7.11, greenishgray (10Y $6 / 2)$ sandy siltstone, collected $\sim 300 \mathrm{~m}$ to the northeast in the laterally equivalent and correlatable bed of B.S.7.6 sample site. 


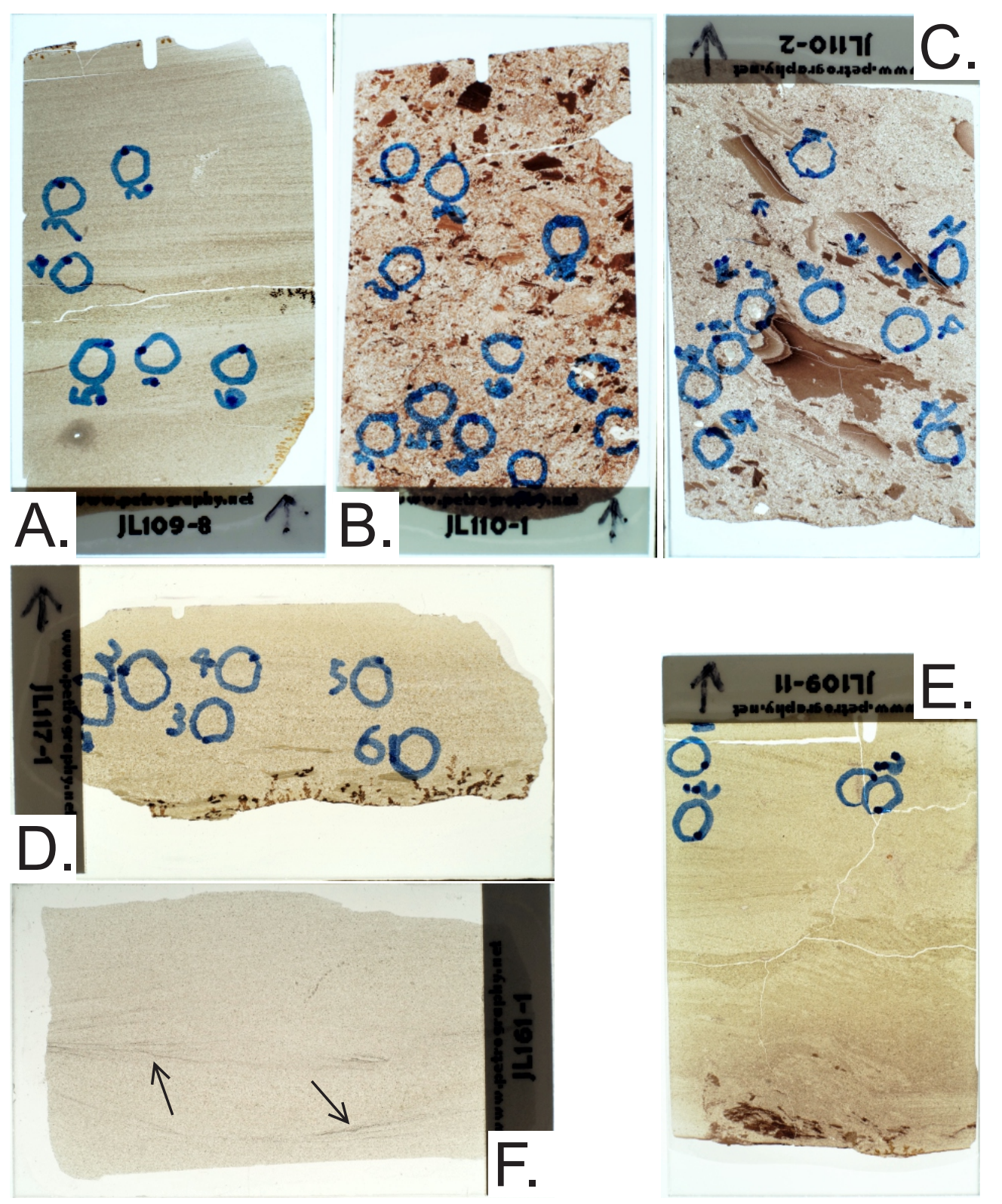

Figure 7. Photomicrographs of thin sections with representative sedimentary structures. Thin sections are in stratigraphic up orientation (except for (F) JL161-1 whose original orientation was not recorded in the field). (A) JL109-8 (2.5Y 5.2, grayish brown) contains undisturbed low-angle crossbeds, assigned to Group I (see text for explanation). (B) JL110-1 (2.5YR 3/2, dusky red) contains mud chips ranging from $<1 \mathrm{~mm}$ to $<5 \mathrm{~mm}$ in length, assigned to Group III. (C) JL110-2 (7.5YR 4/2 (brown) contains large mudchips $>5 \mathrm{~mm}$ long, assigned to Group III. (D) JL117-1 (5Y 5/2 - 7/2, olive gray to light gray) contains flat-lying mud chips present only at the bottom of the sample (part of a fining-up cycle), assigned to Group I. (E) JL109-11 (bottom 10R 3/1, dark reddish gray, and top 5Y 4.5/2, olive gray) contains bedding bioturbated to I.I. 3, assigned to Group II. (F) JL161-1 (10Y 5/1, greenish-gray) contains mud drapes made of $\mu \mathrm{m}$-sized oxide grains with unclearly-defined edges (arrows pointing), assigned to Group I. 

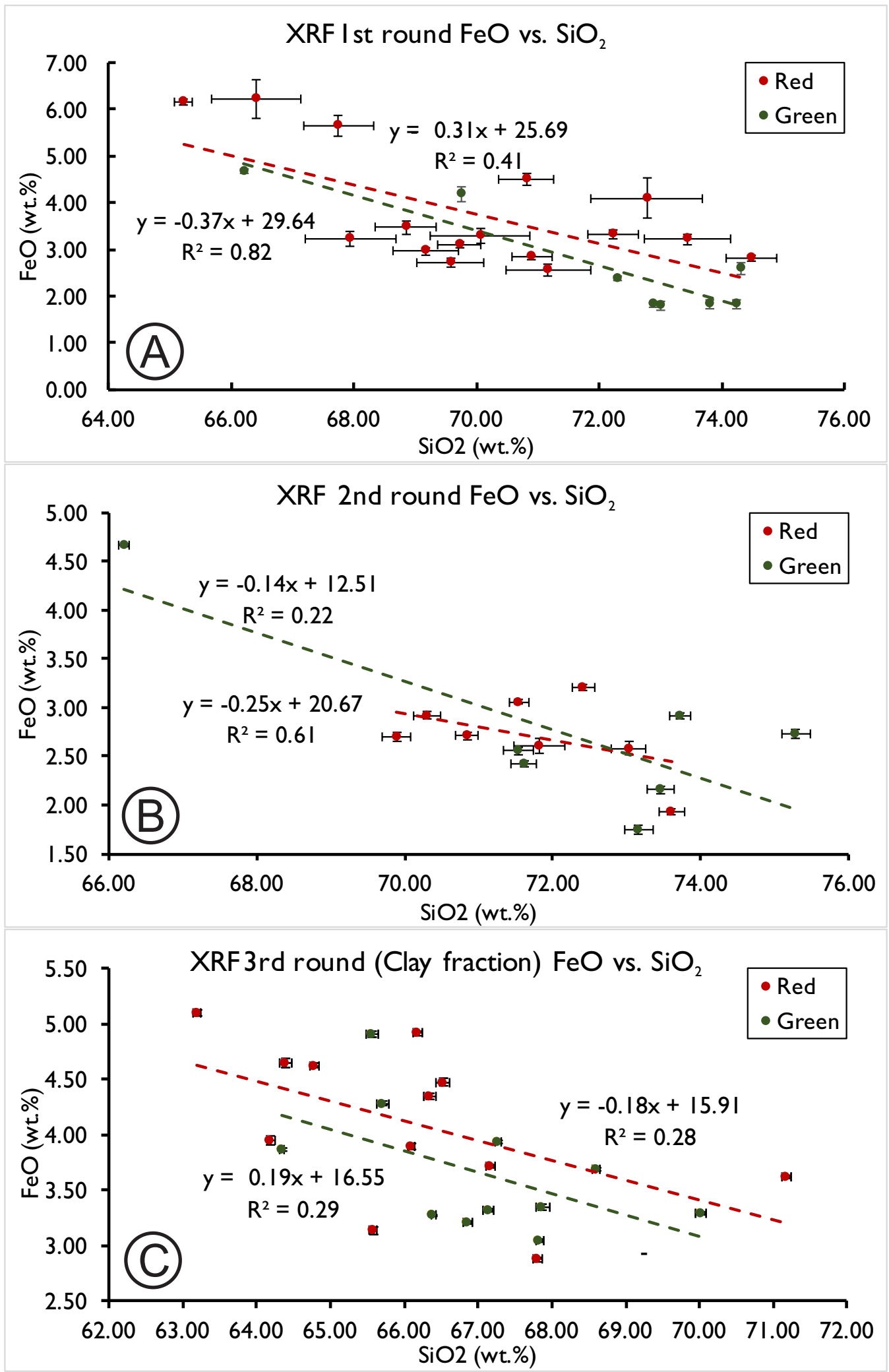

Figure 8. Mean Fe concentration (quantified as $\mathrm{FeO}, \pm 1 \mathrm{SE}$ ) of each sample plotted against mean $\mathrm{Si}$ concentration (quantified as $\mathrm{SiO}_{2}, \pm 1 \mathrm{SE}$ ). (A) Results of the first round of XRF analyses. (B) Results of the second round of analyses (see Methods). 

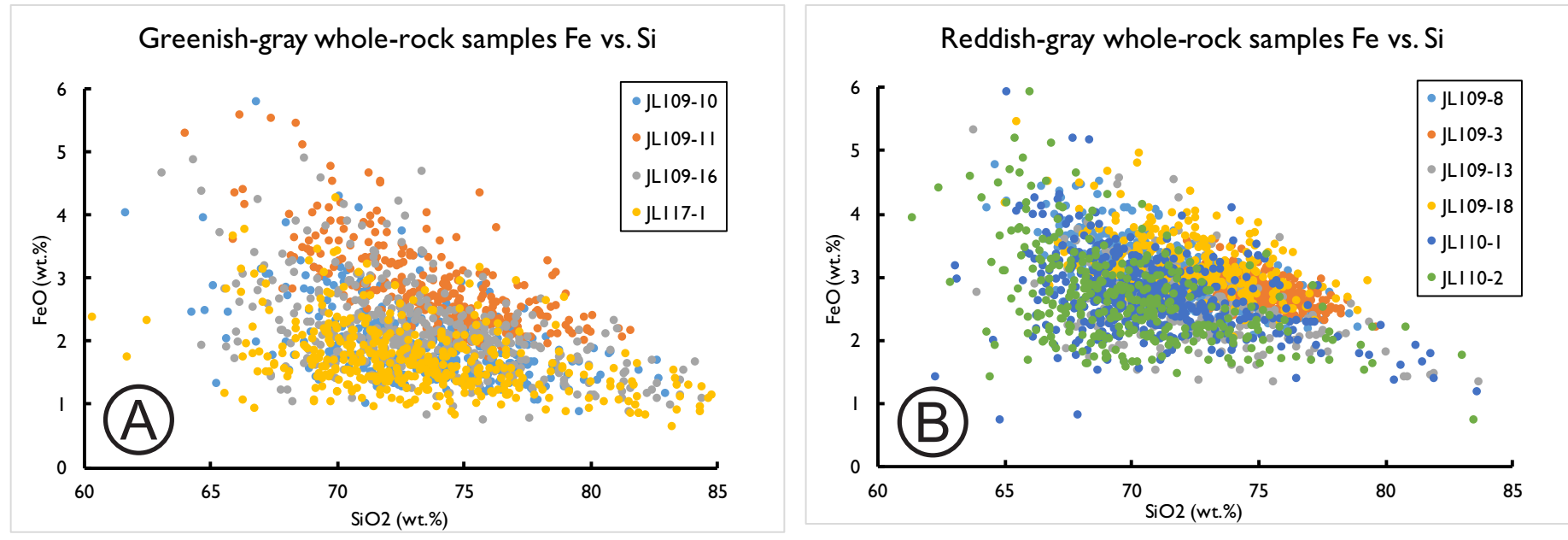

Clay fractions of greenish-gray samples $\mathrm{Fe}$ vs. $\mathrm{Si}$
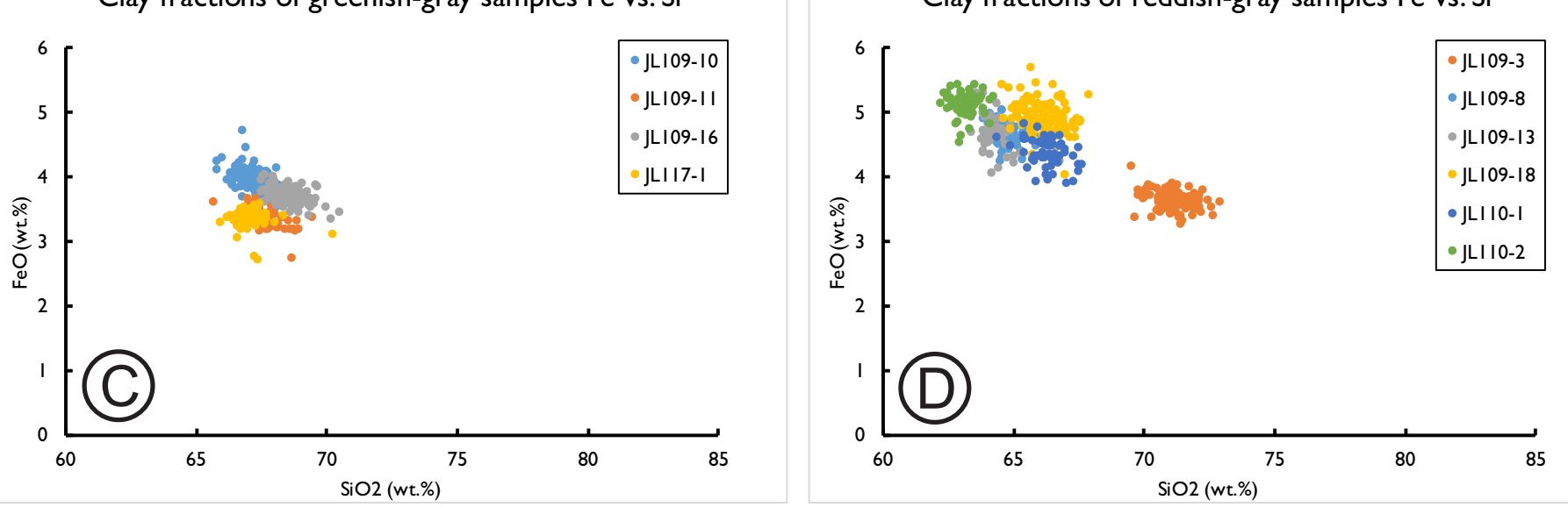

Figure 9. Fe concentration (quantified as $\mathrm{FeO}$ ) of each XRF sampling point plotted against corresponding Si concentration (quantified as $\mathrm{SiO}_{2}$ ). (A) Greenish-gray whole-rock samples. (B) Reddish-gray whole-rock samples. (C) Clay fractions of the same samples in (A). (D) Clay fractions of the same samples in (B). Data for (A) and (B) were obtained during the second round of XRF analyses; data for (C) and (D) were obtained during the third round (see Methods). Only samples with both whole-rock and clay-fraction data are plotted to facilitate comparison. 

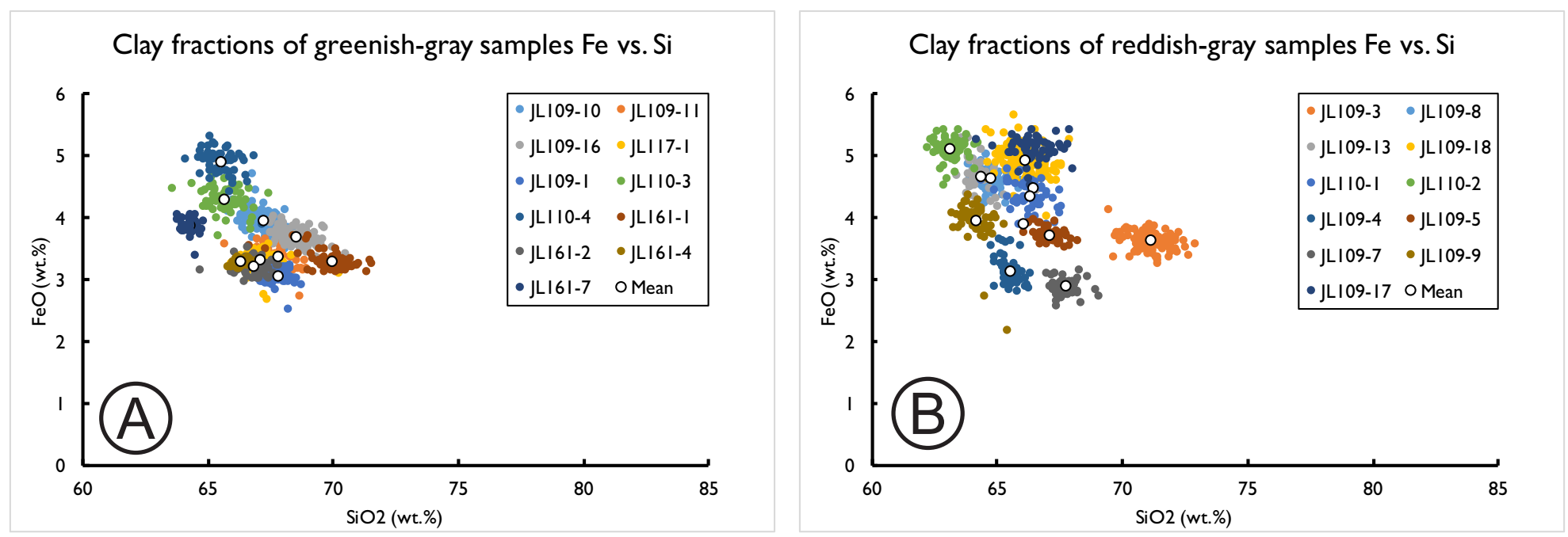

Greenish-gray and reddish-gray data clouds Fe vs. Si

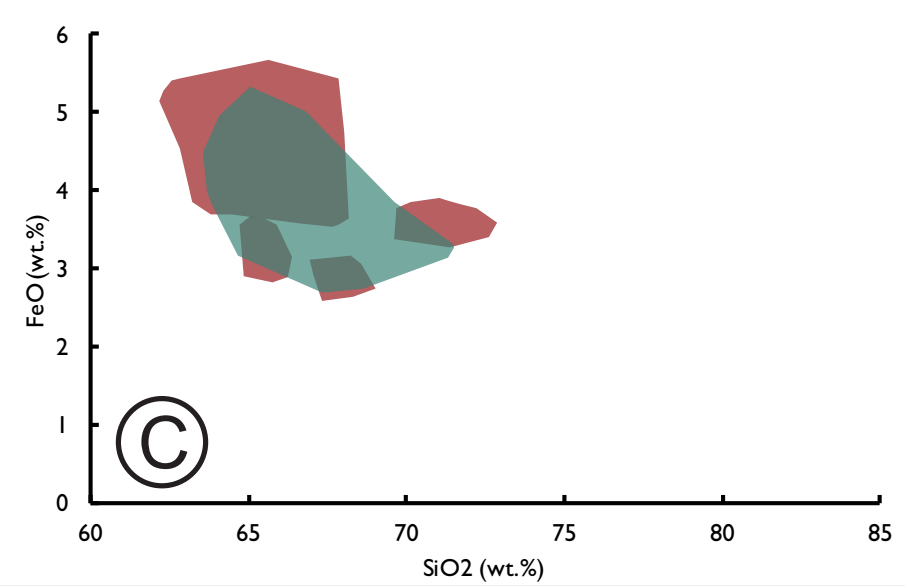

Figure 10. Fe concentration (quantified as $\mathrm{FeO}$ ) plotted against $\mathrm{Si}$ (quantified as $\mathrm{SiO}_{2}$ ). (A) Clay fractions of all greenish-gray samples. (B) Clay fractions of all reddish-gray samples. (C) Polygons that represent the data clouds in (A) and (B). All data used were obtained during the third round of XRF analyses (See Methods). 

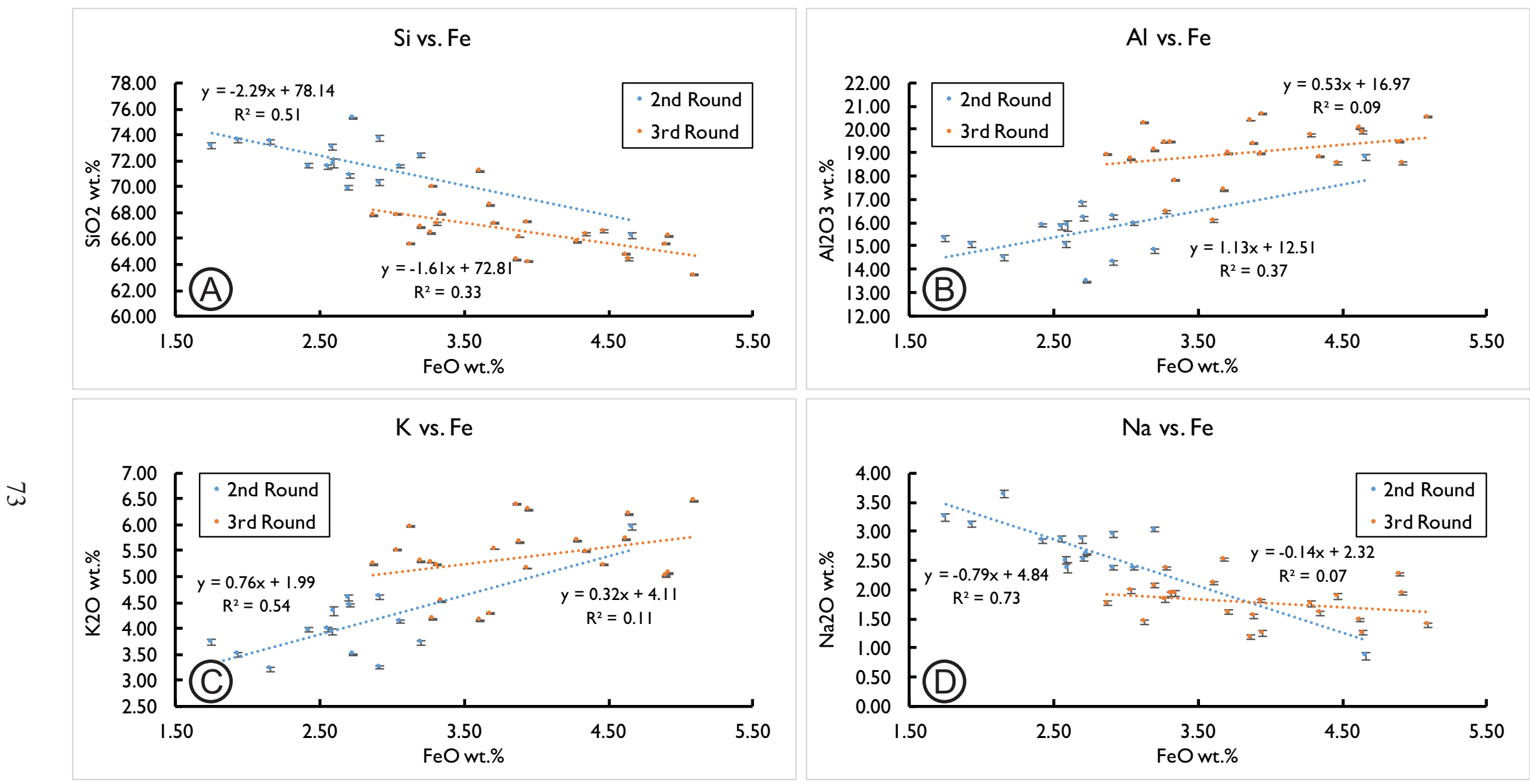

Figure 11. Data from whole-rock samples and exclusively from clay fractions plotted as mean concentrations of major elements (quantified as oxides; \pm 1 SE) plotted against Fe (quantified as FeO). (A) Si vs. Fe. (B) Al vs. Fe. (C) K vs. Fe. (D) Na vs. Fe. (E) Mg vs. Fe. (F) Ca vs. Fe. (G) Ti vs. Fe. (H) Mn vs. Fe. Whole-rock data used were acquired during the second round of XRF analyses. Clay-fraction data were acquired during the third round of XRF analyses. See text for details. 

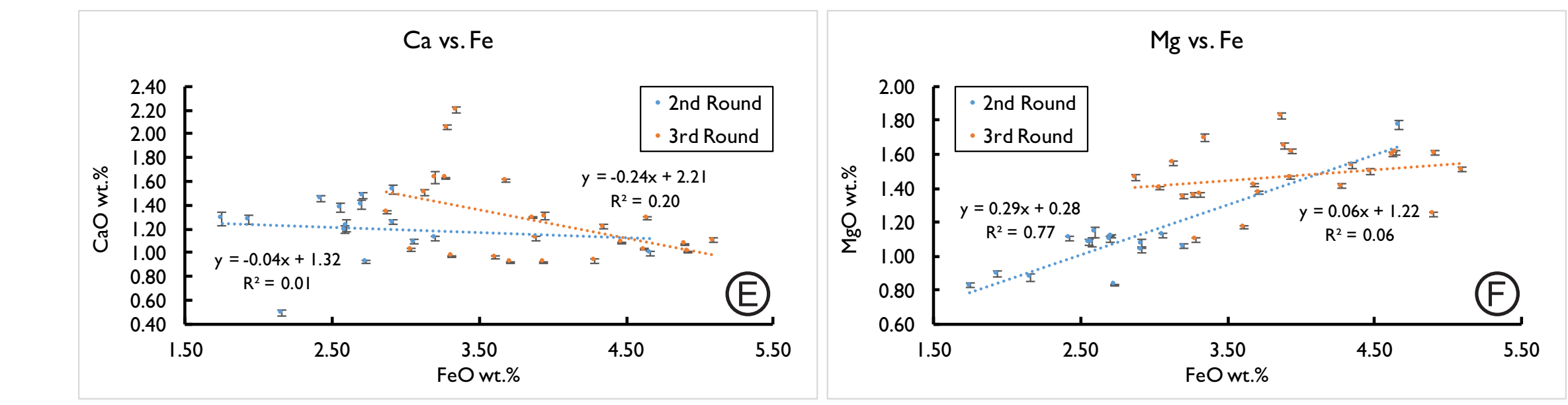

$\not$
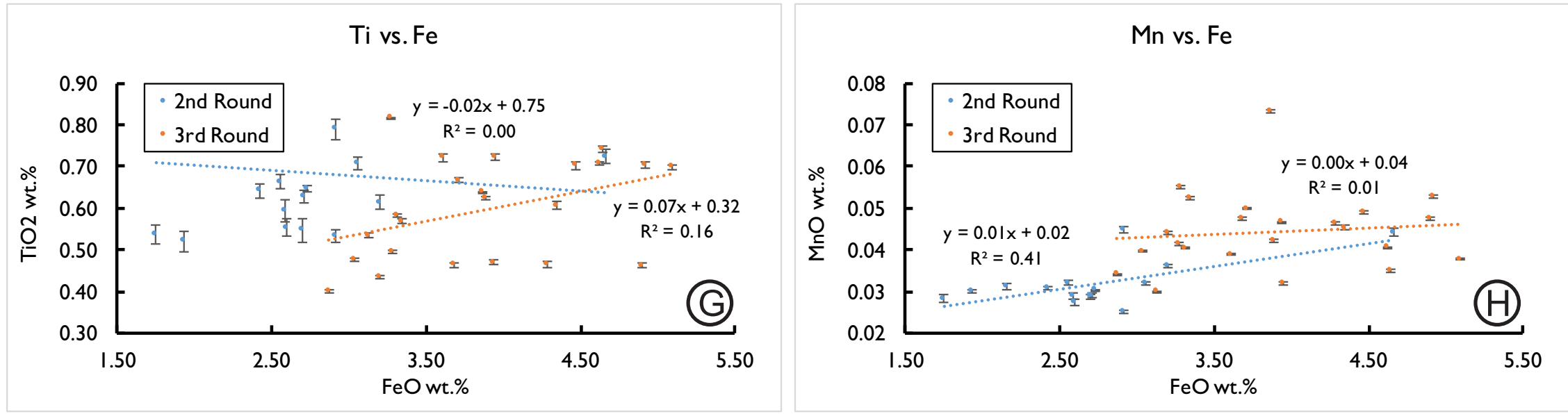

Figure 11. Continued 

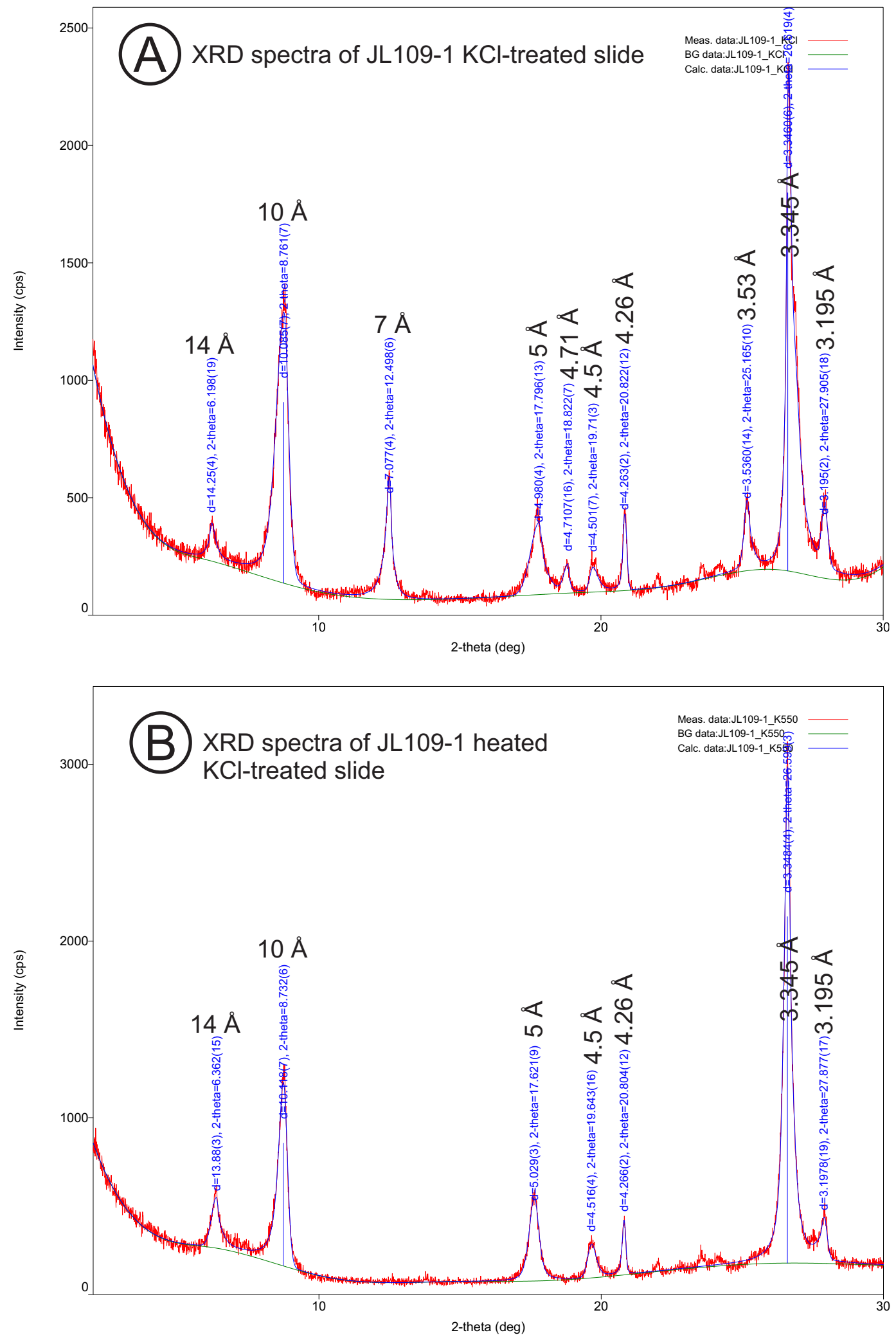

Figure 12. XRD spectra of sample JL109-1 (5GB 5/1, greenish-gray). (A) KCl-treated slide. (B) Heated $\mathrm{KCl}$-trated slide. (C) $\mathrm{MgCl}_{2}$-treated slide. (D) Glycerol-treated slide. Approximate d-spacing used for identification of minerals labeled above/on each peak. XRD spectra obtained from chemically-treated slides of all other samples display the same pattern. 

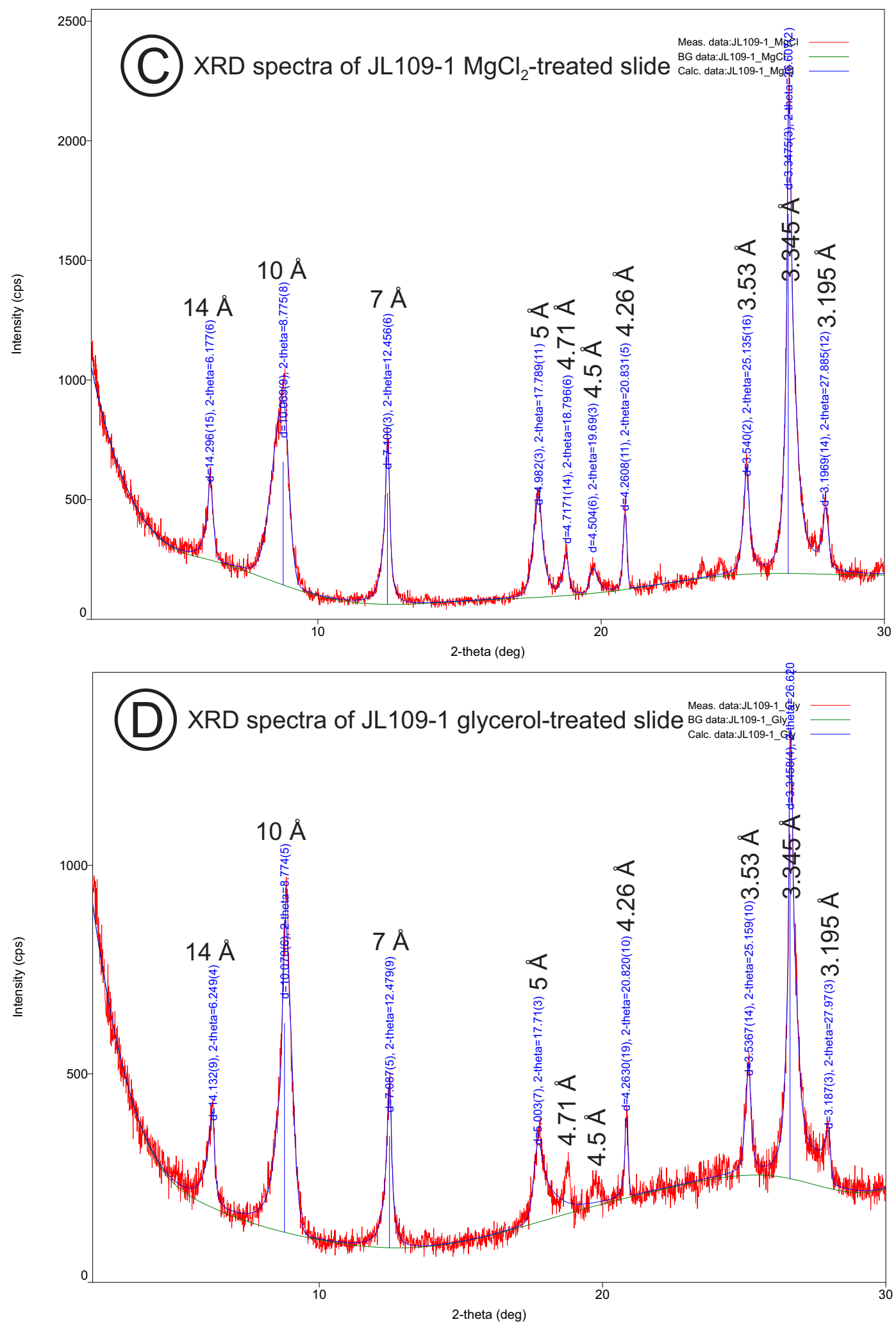

Figure 12. Continued. 


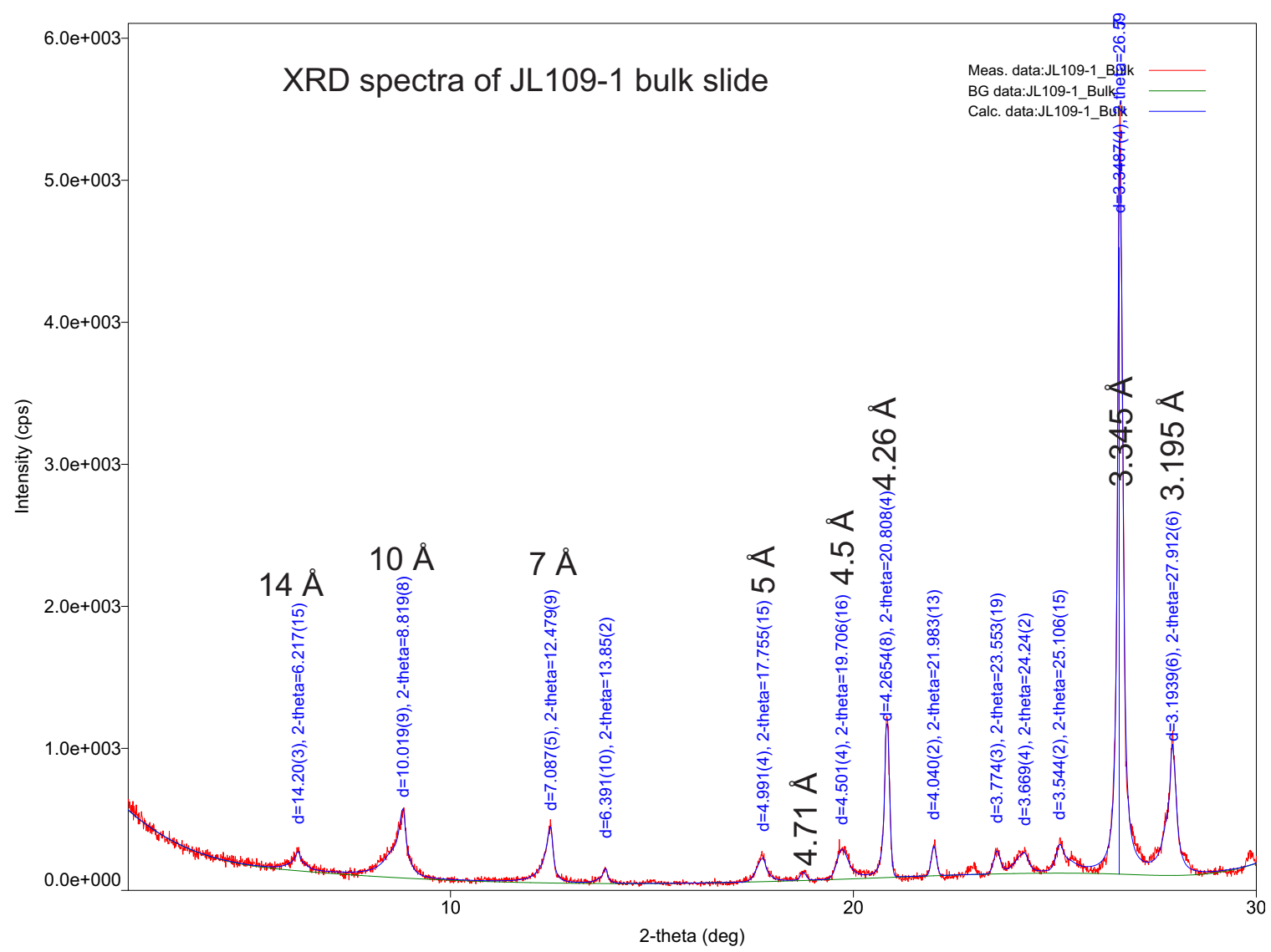

Figure 13. XRD spectra of sample JL109-1 (5GB 5/1, greenish-gray) bulk slide. Note the scale difference of $y$-axis from spectra in Figure 12. Approximate d-spacing used for identification of minerals labeled above/on each peak. Small peaks between $4.26 \AA$ and $3.345 \AA$ peaks are non-primary feldspar peaks. XRD spectra obtained from bulk slides of all other samples display the same pattern. 


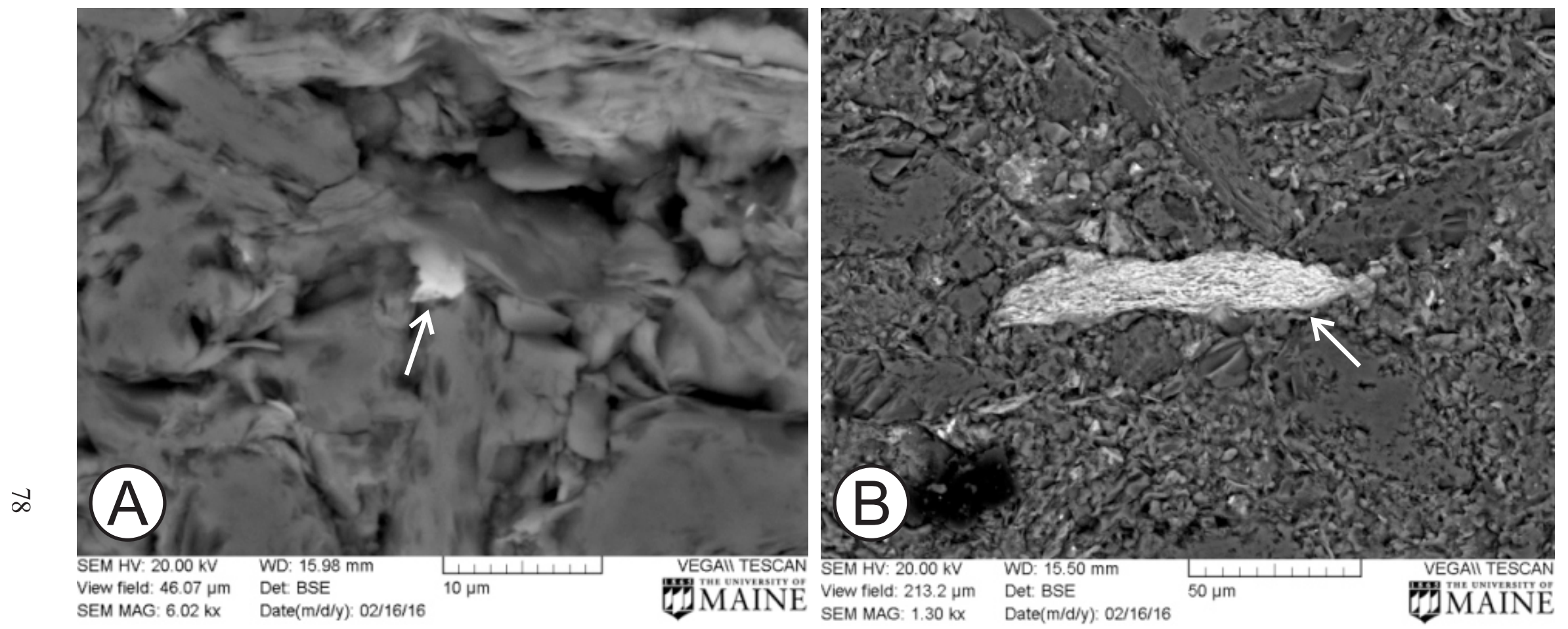

Figure 14. SEM images of hematite morphologies. (A) $\sim 5 \mu \mathrm{m}$ hematite coating on clay mineral (JL109-18). (B) $\sim 100 \mu \mathrm{m}$ hematite coating on clay mineral (B.S.7.6). (C) $\sim 5 \mu \mathrm{m}$ hematite crystal (JL109-3B). (D) $\sim 20 \mu \mathrm{m}$ hematite crystal (B.S.7.6). Arrows point to hematite. Scale as shown. 


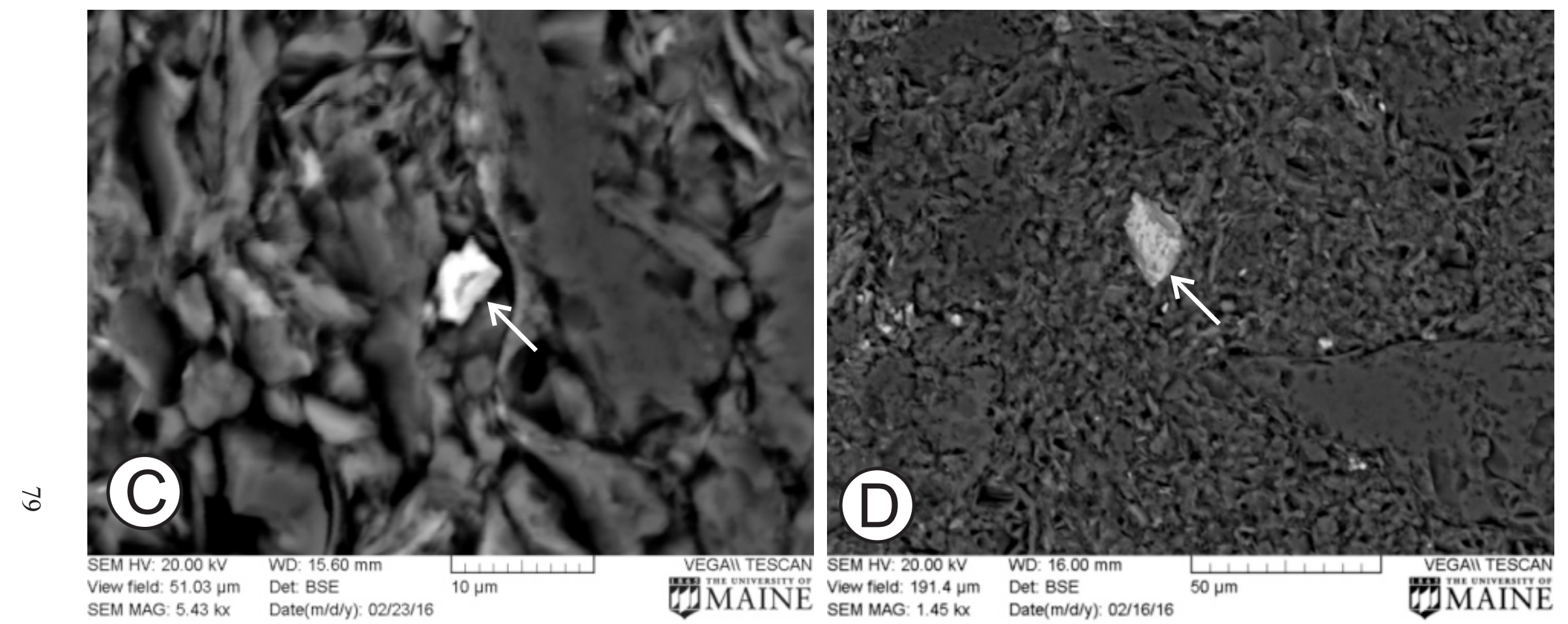

Figure 14. Continued. 


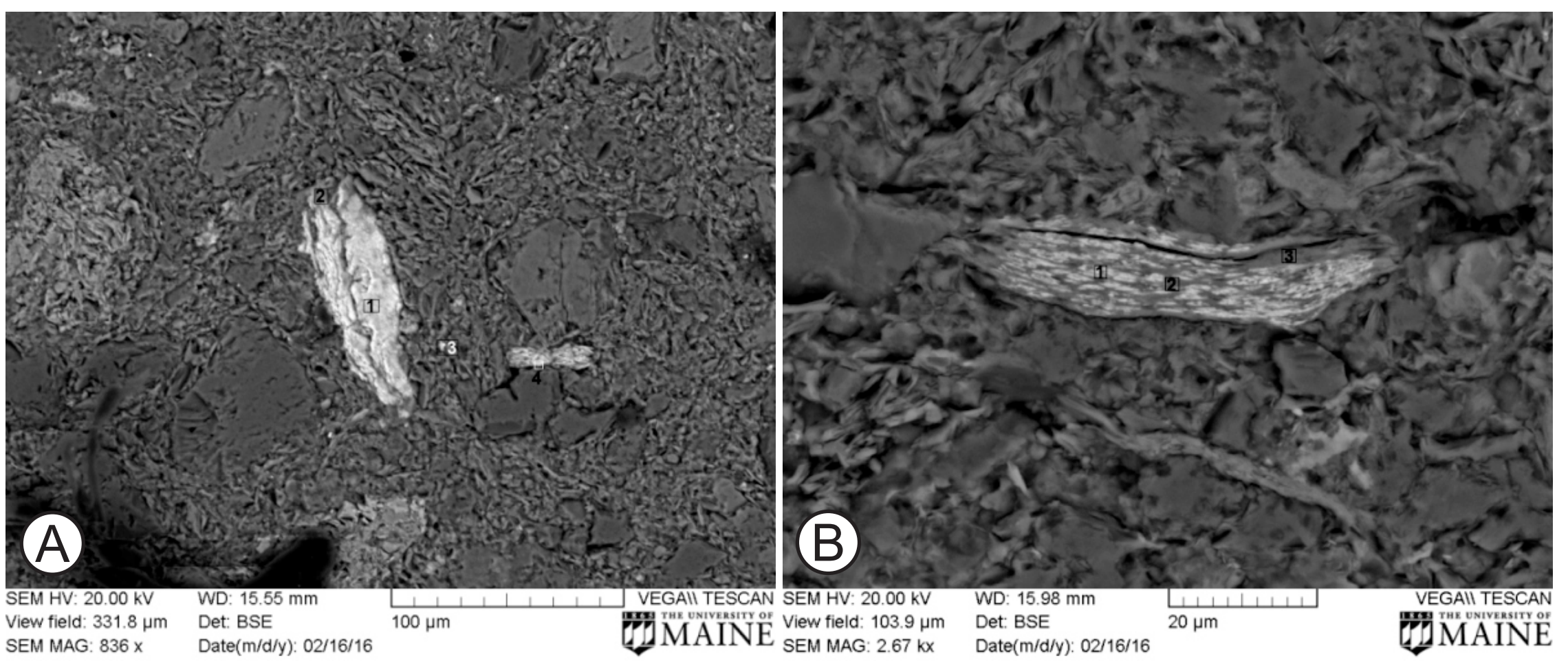

Figure 15. SEM images showing locations from which EDAX data (Table 10) were obtained. (A) Illite grain coated with hematite (B.S.7.6). (B) Chlorite grain coated with hematite (JL109-18). Scale as shown. 


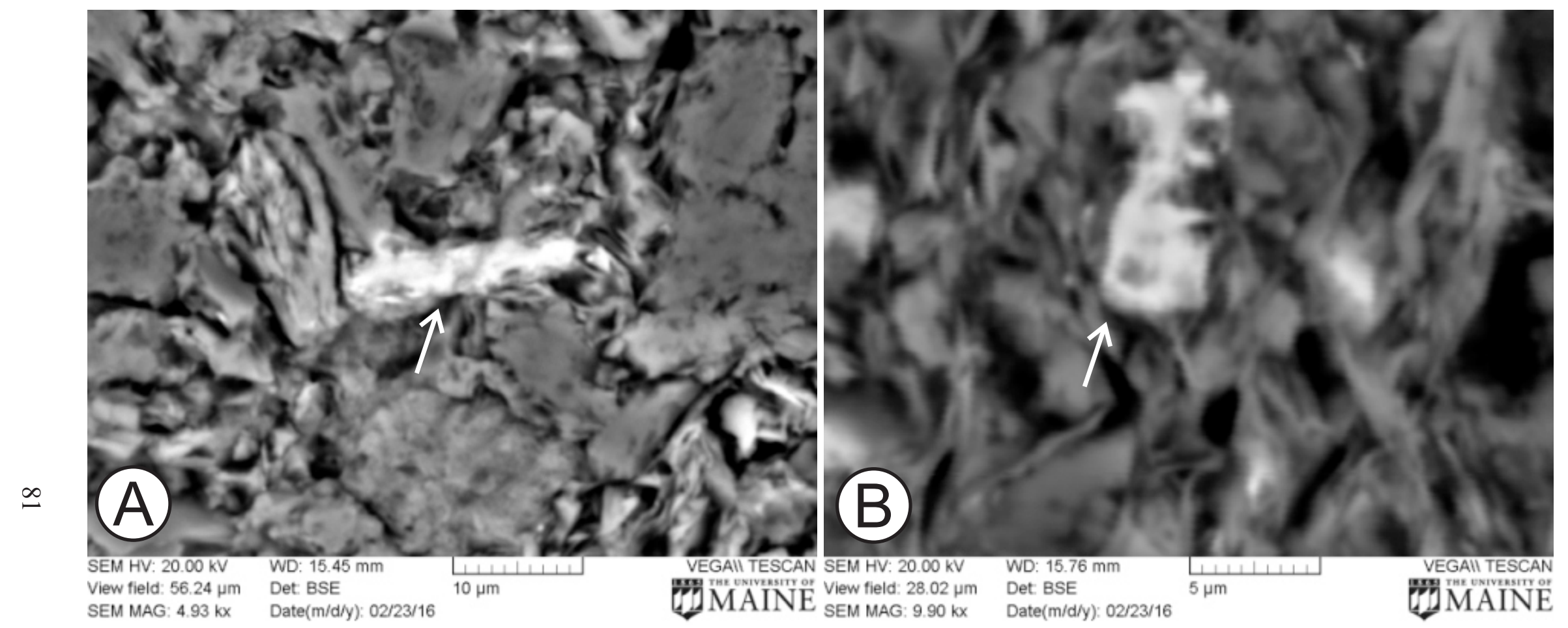

Figure 16. SEM images other minerals with reddish to black coloration. (A) Titanite coating on clay mineral (JL109-18). (B) Rutile coating on clay mineral (JL109-18). (C) Ilmenite crystal (JL109-3B). (D) Magnetite crystal (JL109-18). Arrows point to the minerals. Scale as shown. 


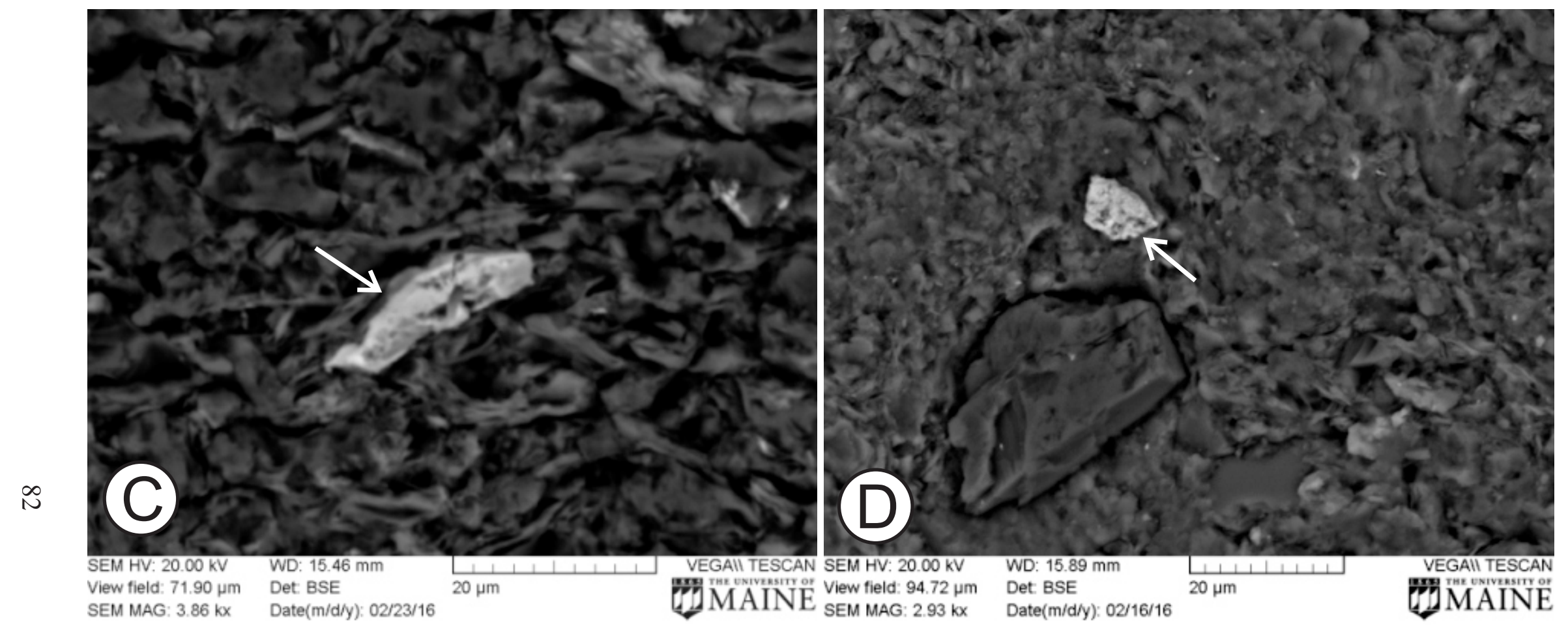

Figure 16. Continued. 

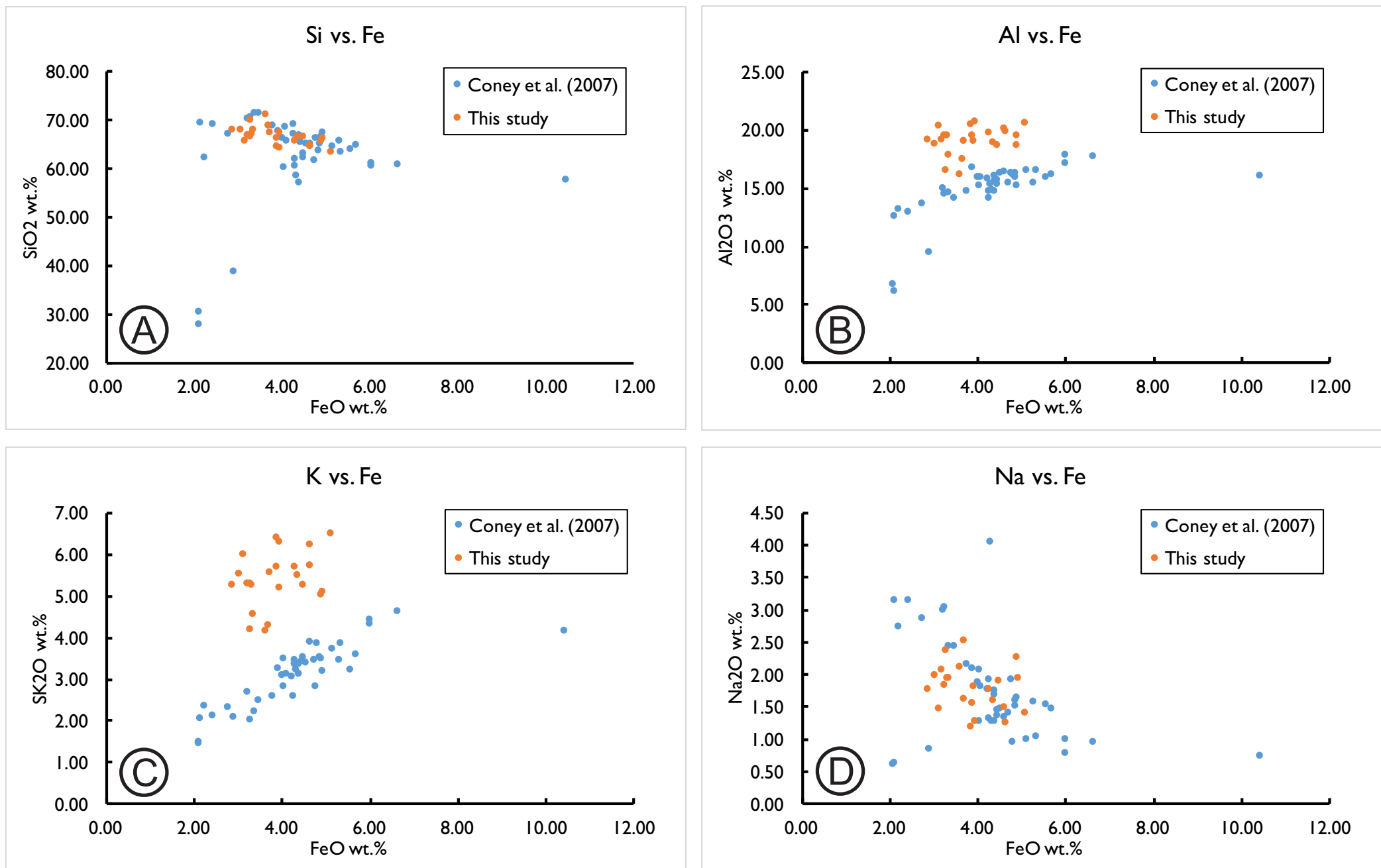

Figure 17. Major element data from Coney et al. (2007) and the clay fractions of samples in this study plotted as mean concentrations of major elements (quantified as oxides) against $\mathrm{Fe}$ (quantified as $\mathrm{FeO}$ ). (A) Si vs. Fe. (B) Al vs. Fe. (C) K vs. Fe. (D) Na vs. Fe. (E) $\mathrm{Mg}$ vs. Fe. (F) Ca vs. Fe. (G) Ca vs. Fe showing data points with $\mathrm{CaO}<8.0$ wt.\%. (H) Ti vs. Fe. (I) Mn vs. Fe. (J) Mn vs. Fe showing data points with $\mathrm{MnO}<0.2 \mathrm{wt} . \%$. 

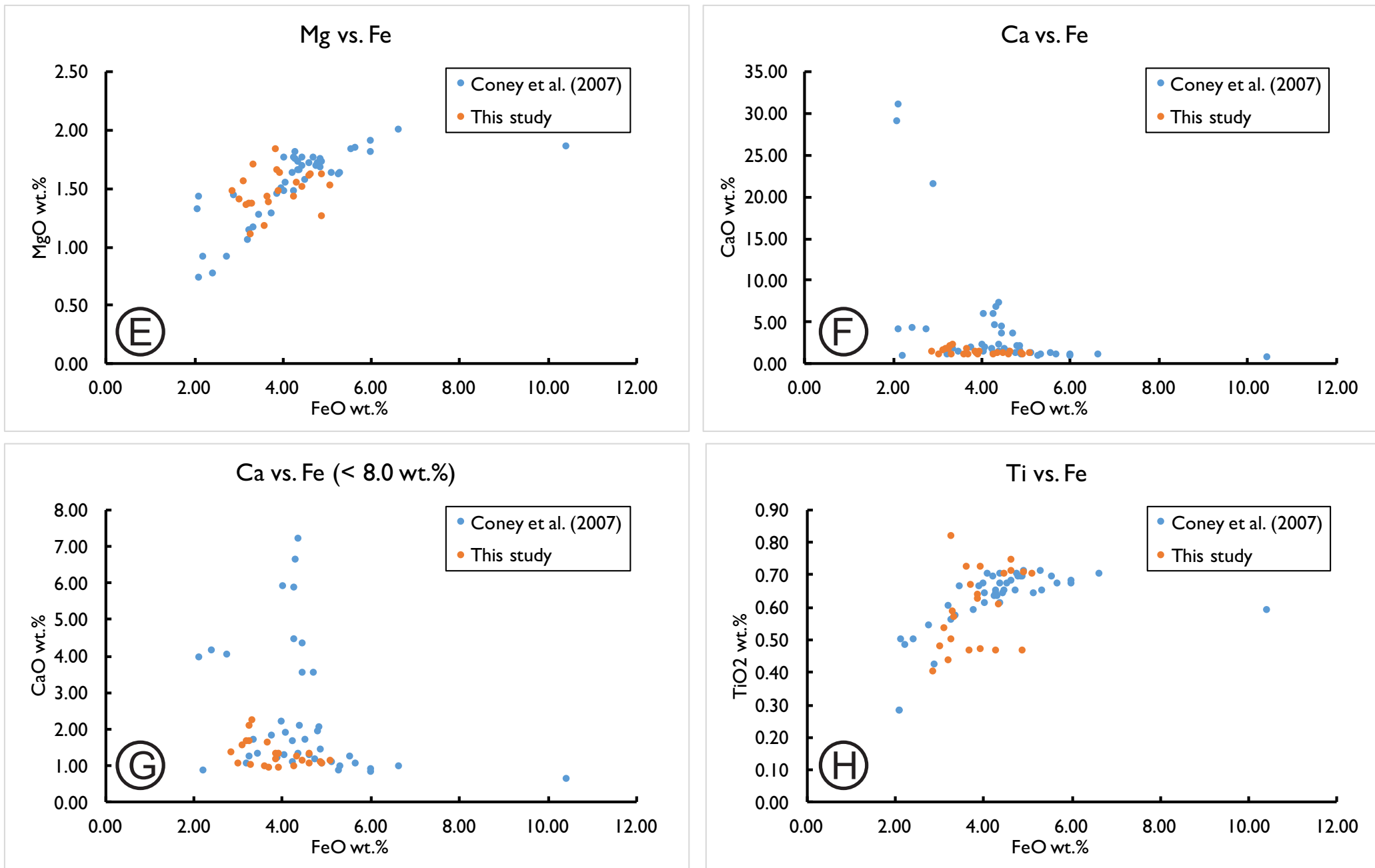

Figure 17. Continued. 

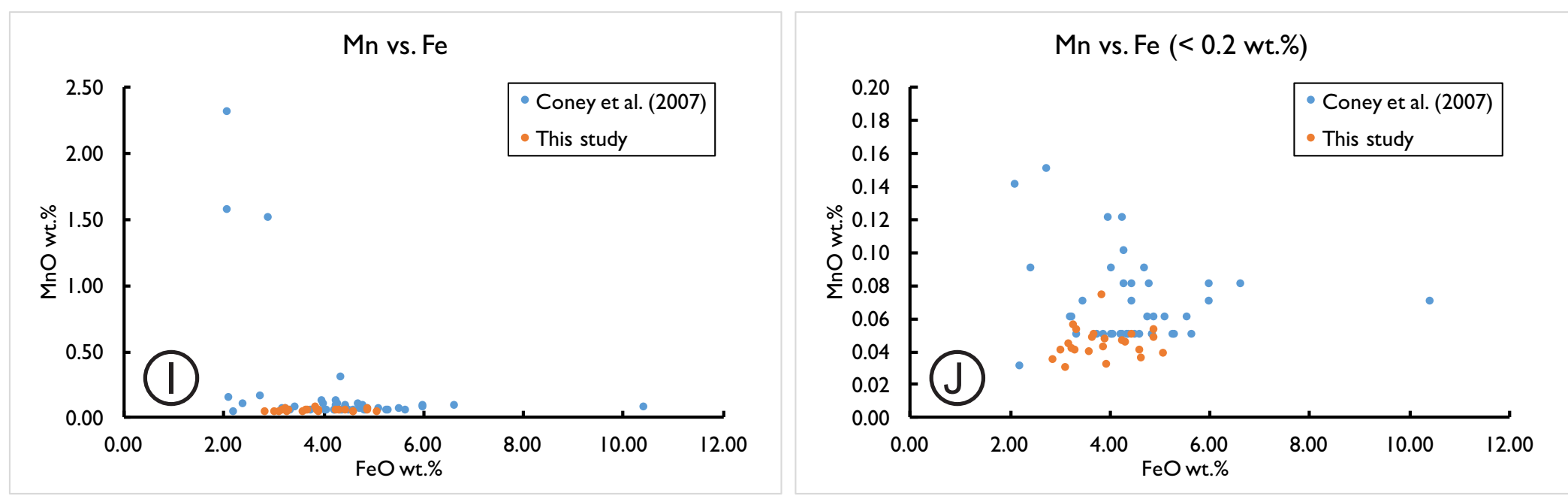

$\infty$

Figure 17. Continued. 

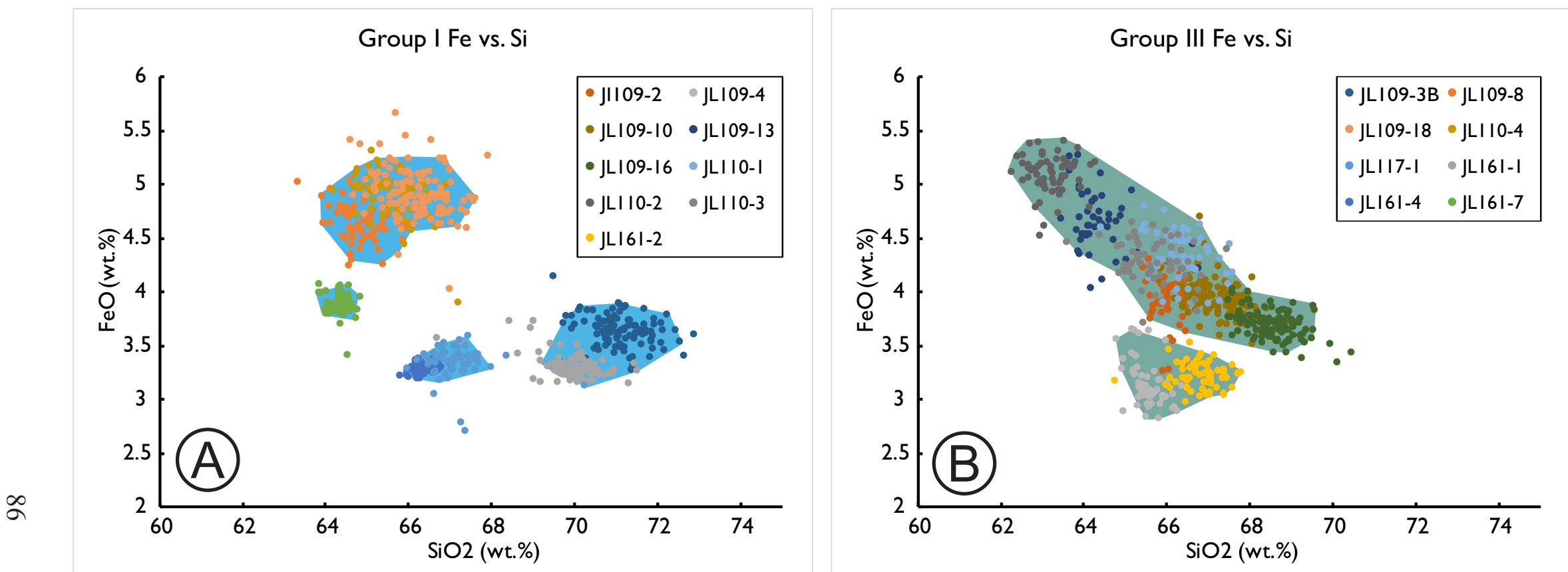

Figure 18. Polygons showing data clouds of Fe concentration (quantified as $\mathrm{FeO}$ ) plotted against $\mathrm{Si}$ concentration $\left(\right.$ quantified as $\left.\mathrm{SiO}_{2}\right)$. (A) Samples in Sedimentary structure Group I. (B) Samples in Group III. The three clusters with lower Fe concentrations in (A) include: JL161-4 (left), JL109-3B, JL161-1 (middle), JL117-1, and JL161-7 (right). 
Table 1. List of Old Lootsberg Pass samples with stratigraphic section name, field described lithology, Munsell color, GPS coordinates, and position relative to the Daptocephalus/Lystrosaurus biozone boundary (BB, see explanation for superscripts). The two italicized samples were collected in January 2016, and all other samples were collected in January 2015. Explanations for superscripts, see page 89.

\begin{tabular}{|c|c|c|c|c|c|c|}
\hline $\begin{array}{l}\text { Sample } \\
\text { number }\end{array}$ & $\begin{array}{c}\text { Stratigraphic } \\
\text { section }\end{array}$ & $\begin{array}{c}\text { Field } \\
\text { lithology }\end{array}$ & Munsell color & Descriptive color & $\begin{array}{c}\text { GPS } \\
\text { coordinates }\end{array}$ & $\begin{array}{c}\text { Position } \\
\text { relative to } \mathrm{BB}\end{array}$ \\
\hline JL109-9 ${ }^{\text {bcf }}$ & Fence section & siltstone & $5 Y R 4 / 1$ & dark gray & $\begin{array}{l}\text { S } 31^{\circ} 47.747^{\prime}, \\
\text { E } 24^{\circ} 48.313^{\prime}\end{array}$ & $+10.9 \mathrm{~m}$ \\
\hline JL109-8 ${ }^{\mathrm{abc}}$ & Fence section & siltstone & $2.5 Y 5 / 2$ & grayish brown & $\begin{array}{l}\text { S } 31^{\circ} 47.747^{\prime}, \\
\text { E } 24^{\circ} 48.313^{\prime}\end{array}$ & $+10.9 \mathrm{~m}$ \\
\hline JL109-7 $7^{\text {bcf }}$ & Fence section & siltstone & $5 Y R 5 / 1$ & gray & $\begin{array}{l}\text { S } 31^{\circ} 47.747^{\prime}, \\
\text { E } 24^{\circ} 48.313^{\prime}\end{array}$ & $+10.9 \mathrm{~m}$ \\
\hline JL 109-10 $0^{\mathrm{abcd}}$ & Fence section & siltstone & $\begin{array}{l}\text { bottom: } 5 \mathrm{YR} 4 / 1 \\
\text { top: } 5 \mathrm{Y} 4 / 1\end{array}$ & $\begin{array}{l}\text { bottom: dark gray } \\
\text { top: dark gray }\end{array}$ & $\begin{array}{l}\text { S } 31^{\circ} 47.747^{\prime}, \\
\text { E } 24^{\circ} 48.313^{\prime}\end{array}$ & $+10.9 \mathrm{~m}$ \\
\hline$J L 161-1^{\mathrm{ab}}$ & Fence section & siltstone & $10 \mathrm{Y} 5 / 1$ & greenish gray & $\begin{array}{l}\text { S } 31^{\circ} 47.747^{\prime}, \\
\text { E } 24^{\circ} 48.313^{\prime}\end{array}$ & $+10.9 \mathrm{~m}$ \\
\hline JL109-1 ${ }^{\text {bcf }}$ & Fence section & siltstone & $5 \mathrm{BG} 5 / 1$ & greenish gray & $\begin{array}{l}\text { S } 31^{\circ} 47.745^{\prime}, \\
\text { E } 24^{\circ} 48.313^{\prime}\end{array}$ & $+11.7 \mathrm{~m}$ \\
\hline $\mathrm{JL} 109-2^{\mathrm{bcf}}$ & Fence section & siltstone & 5YR 3.5/1 & dark to very dark gray & $\begin{array}{l}\text { S } 31^{\circ} 47.745^{\prime}, \\
\text { E } 24^{\circ} 48.313^{\prime}\end{array}$ & $+11.7 \mathrm{~m}$ \\
\hline JL109-3 ${ }^{\text {abcd }}$ & Fence section & siltstone & $5 Y R 3 / 1$ & very dark gray & $\begin{array}{l}\text { S } 31^{\circ} 47.745^{\prime}, \\
\text { E } 24^{\circ} 48.313^{\prime}\end{array}$ & $+11.7 \mathrm{~m}$ \\
\hline$J L 161-2^{\mathrm{ab}}$ & Fence section & siltstone & $10 \mathrm{Y} \mathrm{5/1}$ & greenish gray & $\begin{array}{l}\text { S } 31^{\circ} 47.745^{\prime}, \\
\text { E } 24^{\circ} 48.313^{\prime}\end{array}$ & $+11.7 \mathrm{~m}$ \\
\hline JL109-4 ${ }^{\text {bcf }}$ & Fence section & siltstone & $5 Y R 4 / 1$ & dark gray & $\begin{array}{l}\text { S } 31^{\circ} 47.743^{\prime}, \\
\text { E } 24^{\circ} 48.314^{\prime}\end{array}$ & $+12.9 \mathrm{~m}$ \\
\hline
\end{tabular}


Table 1. Continued.

\begin{tabular}{|c|c|c|c|c|c|c|}
\hline $\begin{array}{l}\text { Sample } \\
\text { number }\end{array}$ & $\begin{array}{c}\text { Stratigraphic } \\
\text { section } \\
\end{array}$ & $\begin{array}{c}\text { Field } \\
\text { lithology }\end{array}$ & Munsell color & Descriptive color & $\begin{array}{c}\text { GPS } \\
\text { coordinates } \\
\end{array}$ & $\begin{array}{l}\text { Position } \\
\text { relative to BB }\end{array}$ \\
\hline $\mathrm{JL} 109-5^{\mathrm{bc}}$ & Fence section & siltstone & 5YR 3/1 & very dark gray & $\begin{array}{l}\text { S } 31^{\circ} 47.743^{\prime} \\
\text { E } 24^{\circ} 48.314^{\prime}\end{array}$ & $+12.9 \mathrm{~m}$ \\
\hline JL109-6 & Fence section & siltstone & $10 \mathrm{YR} 4 / 1$ & dark gray & $\begin{array}{l}\text { S } 31^{\circ} 47.743^{\prime} \\
\text { E } 24^{\circ} 48.314^{\prime}\end{array}$ & $+12.9 \mathrm{~m}$ \\
\hline $\mathrm{JL} 117-1^{\mathrm{abc}}$ & Fence section & siltstone & $5 Y 5 / 2-5 Y 7 / 2$ & olive gray to light gray & $\begin{array}{l}\text { S } 31^{\circ} 47.731^{\prime}, \\
\text { E } 24^{\circ} 48.326^{\prime}\end{array}$ & $+20.6 \mathrm{~m}$ \\
\hline JL109-11 ${ }^{\mathrm{abc}}$ & Fence section & siltstone & $\begin{array}{l}\text { bottom: } 10 \mathrm{R} 3 / 1 \\
\text { top: } 5 \mathrm{Y} 4.5 / 2\end{array}$ & $\begin{array}{l}\text { bottom: dark reddish gray } \\
\text { top: olive gray }\end{array}$ & $\begin{array}{l}\text { S } 31^{\circ} 47.731^{\prime}, \\
\text { E } 24^{\circ} 48.326^{\prime}\end{array}$ & $+20.6 \mathrm{~m}$ \\
\hline JL109-12 & Fence section & siltstone & 10R 3/1 & dark reddish gray & $\begin{array}{l}\text { S } 31^{\circ} 47.731^{\prime}, \\
\text { E } 24^{\circ} 48.326^{\prime}\end{array}$ & $+20.6 \mathrm{~m}$ \\
\hline JL109-13 $3^{\mathrm{abc}}$ & Fence section & siltstone & 10R 3/1 & dark reddish gray & $\begin{array}{l}\text { S } 31^{\circ} 47.731^{\prime}, \\
\text { E } 24^{\circ} 48.326^{\prime}\end{array}$ & $+20.6 \mathrm{~m}$ \\
\hline JL110-1 ${ }^{\text {abce }}$ & Fence section & siltstone & $2.5 \mathrm{YR} 3 / 2$ & dusky red & $\begin{array}{l}\text { S } 31^{\circ} 47.727^{\prime} \\
\text { E } 24^{\circ} 48.340^{\prime}\end{array}$ & $+27.95 \mathrm{~m}$ \\
\hline $\mathrm{JL} 110-2^{\mathrm{abc}}$ & Fence section & siltstone & $7.5 \mathrm{YR} 4 / 2$ & brown & $\begin{array}{l}\text { S } 31^{\circ} 47.721^{\prime}, \\
\text { E } 24^{\circ} 48.349^{\prime}\end{array}$ & $+27.95 \mathrm{~m}$ \\
\hline $\mathrm{JL} 110-3^{\mathrm{abc}}$ & Fence section & siltstone & $5 Y 5.5 / 2$ & $\begin{array}{l}\text { olive gray to light olive } \\
\text { gray }\end{array}$ & $\begin{array}{l}\text { S } 31^{\circ} 47.721^{\prime}, \\
\text { E } 24^{\circ} 48.349^{\prime}\end{array}$ & $+27.95 \mathrm{~m}$ \\
\hline JL109-16 & Fence section & siltstone & $\begin{array}{l}\text { bottom: } 5 Y 4 / 1 \\
\text { top: } 5 \text { YR } 4 / 1\end{array}$ & $\begin{array}{l}\text { bottom: dark gray } \\
\text { top: dark gray }\end{array}$ & $\begin{array}{l}\text { S } 31^{\circ} 47.712^{\prime} \\
\text { E } 24^{\circ} 48.354^{\prime}\end{array}$ & $+42.4 \mathrm{~m}$ \\
\hline JL109-17 $7^{\text {bcf }}$ & Fence section & siltstone & 5YR 3.5/1 & dark to very dark gray & $\begin{array}{l}\text { S } 31^{\circ} 47.712^{\prime} \\
\text { E } 24^{\circ} 48.354^{\prime}\end{array}$ & $+42.4 \mathrm{~m}$ \\
\hline
\end{tabular}


Table 1. Continued.

\begin{tabular}{|c|c|c|c|c|c|c|}
\hline $\begin{array}{l}\text { Sample } \\
\text { number }\end{array}$ & $\begin{array}{c}\text { Stratigraphic } \\
\text { section }\end{array}$ & $\begin{array}{c}\text { Field } \\
\text { lithology }\end{array}$ & Munsell color & Descriptive color & $\begin{array}{c}\text { GPS } \\
\text { coordinates }\end{array}$ & $\begin{array}{c}\text { Position } \\
\text { relative to } \mathrm{BB}\end{array}$ \\
\hline JL109-18 & Fence section & siltstone & $5 Y R 3 / 1$ & very dark gray & $\begin{array}{l}\text { S } 31^{\circ} 47.712^{\prime}, \\
\text { E } 24^{\circ} 48.354^{\prime}\end{array}$ & $+42.4 \mathrm{~m}$ \\
\hline JL109-19 & Fence section & siltstone & 10R 3/1 & dark reddish gray & $\begin{array}{l}\text { S } 31^{\circ} 47.712^{\prime}, \\
\text { E } 24^{\circ} 48.354^{\prime}\end{array}$ & $+42.4 \mathrm{~m}$ \\
\hline JL109-14 & East section (?) & siltstone & $5 Y 4 / 2$ & olive gray & $\begin{array}{l}\text { S } 31^{\circ} 47.755^{\prime}, \\
\text { E } 24^{\circ} 48.364^{\prime}\end{array}$ & $+18.0 \mathrm{~m}$ \\
\hline JL109-15 & East section (?) & siltstone & $10 \mathrm{R} 4 / 1$ & dark reddish gray & $\begin{array}{l}\text { S } 31^{\circ} 47.755^{\prime}, \\
\text { E } 24^{\circ} 48.364^{\prime}\end{array}$ & $+18.0 \mathrm{~m}$ \\
\hline JL110-4 ${ }^{\text {bcf }}$ & $\begin{array}{l}\text { Waterworn } \\
\text { section }\end{array}$ & siltstone & $5 Y 6 / 2$ & light olive gray & $\begin{array}{l}\text { S } 31^{\circ} 47.686^{\prime}, \\
\text { E } 24^{\circ} 48.254^{\prime}\end{array}$ & $\sim+27.95 \mathrm{~m}$ \\
\hline$J L 110-6^{a}$ & $\begin{array}{c}\text { Woody Gulley } \\
\text { section }\end{array}$ & siltstone & $5 \mathrm{GY} 5 / 1$ & greenish gray & $\begin{array}{l}\text { S } 31^{\circ} 47.692^{\prime}, \\
\text { E } 24^{\circ} 47.789^{\prime}\end{array}$ & $\sim+19.5 \mathrm{~m}$ \\
\hline
\end{tabular}

Explanations for superscripts:

a, samples with accompanying thin sections;

b, samples with corresponding clay slides;

c, samples analyzed for clay mineralogy by XRD at Southern Methodist University;

d, samples sent out for Mössbauer spectroscopic analysis at Mount Holyoke College in August 2015;

e, sample sent out for Mössbauer spectroscopy in February 2016;

$\mathrm{f}$, hand samples polished for examination of sedimentary structures;

1, BB = Biozone Boundary between the Daptocephalus and Lystrosaurus Assemblage Zones at OLP, determined based on vertebrate fossil data of Smith and Botha-Brink (2014). 
Table 2. List of Bethulie samples with field described lithology, Munsell color, GPS coordinates, and position relative to the Biozone Boundary. Italicized samples were collected in January 2016, and the other two samples were collected in January 2015. Explanations for superscripts are the same as Table 1 (page 89).

\begin{tabular}{|c|c|c|c|c|c|}
\hline $\begin{array}{l}\text { Sample } \\
\text { number }\end{array}$ & $\begin{array}{c}\text { Field } \\
\text { lithology }\end{array}$ & Munsell color & $\begin{array}{c}\text { Descriptive } \\
\text { color }\end{array}$ & $\begin{array}{c}\text { GPS } \\
\text { coordinates }\end{array}$ & $\begin{array}{c}\text { Position } \\
\text { relative to } \mathrm{BB}\end{array}$ \\
\hline B.S.7.6 $6^{\mathrm{ad}}$ & siltstone & 5YR 4/1 & dark gray & $\begin{array}{l}\text { S } 30^{\circ} 41.838^{\prime} \\
\text { E } 26^{\circ} 26.785^{\prime}\end{array}$ & $0 \mathrm{~cm}$ \\
\hline B.S.7.11 & siltstone & $10 \mathrm{Y} 6 / 2$ & greenish gray & $\begin{array}{l}\text { S } 30^{\circ} 41.838^{\prime} \\
\text { E } 26^{\circ} 26.785^{\prime}\end{array}$ & $\begin{array}{c}0 \mathrm{~cm} \text { (lateral } \\
\text { equivalent) }\end{array}$ \\
\hline$J L 161-7^{\mathrm{ab}}$ & siltstone & $10 \mathrm{GY} 5 / 1$ & greenish gray & $\begin{array}{l}\text { S } 30^{\circ} 41.838^{\prime}, \\
\text { E } 26^{\circ} 26.785^{\prime}\end{array}$ & $-105 \mathrm{~cm}$ \\
\hline$J L 161-4^{\text {abe }}$ & siltstone & $10 \mathrm{Y} 6 / 1$ & greenish gray & $\begin{array}{l}\text { S } 30^{\circ} 41.838^{\prime}, \\
\text { E } 26^{\circ} 26.785^{\prime}\end{array}$ & $-275 \mathrm{~cm}$ \\
\hline
\end{tabular}


Table 3. Procedures for the $\mathrm{KCl}, \mathrm{MgCl}_{2}$, and Glycerol treatments applied to clay films prepared using the method after Pollestro (1982).

1. Each clay film was flushed with $\mathrm{dH}_{2} \mathrm{O}$ before treated with the following solutions.

2. Solutions used to flush the clay films in each step of the treatments

\begin{tabular}{cccc}
\hline & \multicolumn{3}{c}{$\mathrm{KCl}$ treatment $\mathrm{MgCl}_{2}$ treatment } \\
Step 1 & $1 \mathrm{M} \mathrm{KCl}$ & $3.0 \mathrm{pH} \mathrm{HCl}$ & $3.0 \mathrm{pH} \mathrm{HCl}$ \\
Step 2 & $\mathrm{dH}_{2} \mathrm{O}$ & $0.5 \mathrm{M} \mathrm{MgCl}_{2}$ & $0.5 \mathrm{M} \mathrm{MgCl}_{2}$ \\
Step 3 & & $\mathrm{dH}_{2} \mathrm{O}$ & $\mathrm{dH}_{2} \mathrm{O}$ \\
Step 4 & & & $1: 4$ glycerol \\
\hline
\end{tabular}

3. Clay films were transferred onto petrographic slides. 
Table 4. Sedimentary structures present in thin sections and polished hand samples.

\begin{tabular}{|c|c|c|c|c|c|c|c|c|}
\hline \multirow[b]{2}{*}{ Number } & \multirow[b]{2}{*}{ Section } & \multirow[b]{2}{*}{ Bedding } & \multicolumn{2}{|c|}{ Mud chips } & \multicolumn{2}{|c|}{ Bioturbation } & \multirow[b]{2}{*}{ Notes } & \multirow{2}{*}{$\begin{array}{c}\text { Assigned } \\
\text { Group }\end{array}$} \\
\hline & & & Size & Density & Burrow size & $\begin{array}{c}\text { Intensity } \\
\text { (I.I.) }\end{array}$ & & \\
\hline \multicolumn{9}{|c|}{ Thin Sections } \\
\hline JL109-3A & & throughout, intact & - & - & $\begin{array}{c}<=1 \mathrm{~mm} \text { and } \\
1 \sim 5 \mathrm{~mm}\end{array}$ & 2 & \multirow[b]{6}{*}{$\begin{array}{l}\text { mud chips only at base, } \\
\text { incorporated from lower } \\
\text { layer, possibly due to } \\
\text { bioturbation }\end{array}$} & I \\
\hline JL109-3B & & throughout, intact & - & - & $\begin{array}{c}1 \sim 5 \mathrm{~mm} \text { to }>5 \\
\mathrm{~mm}\end{array}$ & 2 & & I \\
\hline JL109-8 & & throughout, intact & - & - & $<=1 \mathrm{~mm}$ & 1 & & I \\
\hline \multirow[b]{2}{*}{ JL109-10 } & Top green & - & - & - & - & 5 & & III \\
\hline & Bottom red & throughout, partial & - & - & $\begin{array}{c}<=1 \mathrm{~mm} \text { and } \\
1 \sim 5 \mathrm{~mm}\end{array}$ & $2 \sim 3$ & & II \\
\hline JL109-11 & & throughout, partial & $<1 \mathrm{~mm}$ to $>5 \mathrm{~mm}$ & $\sim 10 \%$ & - & 3 & & II \\
\hline JL109-13 & & throughout, partial & - & - & $\begin{array}{c}<=1 \mathrm{~mm} \text { to } \\
1 \sim 5 \mathrm{~mm}\end{array}$ & $3 \sim 4$ & & III \\
\hline JL109-14 & Top green & $\begin{array}{l}\text { two fining-up } \\
\text { cycles, intact }\end{array}$ & $<1 \mathrm{~mm}$ & 0.15 & - & 1 & $\begin{array}{l}\text { mud chips only at the } \\
\text { base of the top fining-up } \\
\text { cycle, likely incorporated } \\
\text { from the fine part of the } \\
\text { lower fining-up cycle }\end{array}$ & I \\
\hline
\end{tabular}


Table 4. Continued.

\begin{tabular}{|c|c|c|c|c|c|c|c|c|}
\hline \multirow[b]{2}{*}{ Number } & \multirow[b]{2}{*}{ Section } & \multirow[b]{2}{*}{ Bedding } & \multicolumn{2}{|c|}{ Mud chips } & \multicolumn{2}{|c|}{ Bioturbation } & \multirow[b]{2}{*}{ Notes } & \multirow{2}{*}{$\begin{array}{c}\text { Assigned } \\
\text { Group }\end{array}$} \\
\hline & & & Size & Density & Burrow size & $\begin{array}{c}\text { Intensity } \\
\text { (I.I.) }\end{array}$ & & \\
\hline \multicolumn{9}{|c|}{ Thin Sections } \\
\hline JL109-14 & Bottom red & throughout, partial & $<1 \mathrm{~mm}$ & $15 \%$ & $\begin{array}{c}1 \sim 5 \mathrm{~mm} \text { to }>5 \\
\mathrm{~mm}\end{array}$ & 3 & $\begin{array}{l}\text { in three patches, likely } \\
\text { separated by two large } \\
\text { burrows }\end{array}$ & II \\
\hline \multirow{2}{*}{ JL109-15 } & Right & throughout, intact & - & - & $<=1 \mathrm{~mm}$ & 2 & & I \\
\hline & Left & - & $<1 \mathrm{~mm}$ & $10 \sim 15 \%$ & $<=1 \mathrm{~mm}$ & $4 \sim 5$ & & III \\
\hline \multirow{2}{*}{ JL109-16 } & Top red & throughout, intact & - & - & $1 \sim 5 \mathrm{~mm}$ & $1 \sim 2$ & & I \\
\hline & Bottom green & - & - & - & $<=1 \mathrm{~mm}$ & 4 & & III \\
\hline JL109-18 & & throughout, intact & - & - & $<=1 \mathrm{~mm}$ & $1 \sim 2$ & & $\mathrm{I}$ \\
\hline JL110-1 & & - & $<1 \mathrm{~mm}$ to $1 \sim 5 \mathrm{~mm}$ & $20 \%$ & $<=1 \mathrm{~mm}$ & 5 & $\begin{array}{l}\text { matrix is more clayey } \\
\text { than JL110-2 }\end{array}$ & III \\
\hline JL110-2 & & - & $<1 \mathrm{~mm}$ to $>5 \mathrm{~mm}$ & $15 \%$ & $<=1 \mathrm{~mm}$ & 5 & $\begin{array}{l}\text { mud chips aligned upper } \\
\text { left-lower right, internal } \\
\text { bedding still in fining-up } \\
\text { position }\end{array}$ & III \\
\hline \multirow{3}{*}{ JL110-3 } & Top & throughout, intact & - & - & - & 1 & & I \\
\hline & Middle & - & $<1 \mathrm{~mm}$ to $1 \sim 5 \mathrm{~mm}$ & $15-20 \%$ & $1 \sim 5 \mathrm{~mm}$ & 5 & & III \\
\hline & Bottom & - & - & - & - & 1 & & I \\
\hline JL110-5 & & throughout, intact & - & - & $<=1 \mathrm{~mm}$ & 1 & $\begin{array}{l}\text { flattened burrows (?) 5- } \\
7 \%\end{array}$ & I \\
\hline JL110-6 & & - & - & - & $<=1 \mathrm{~mm}$ & 5 & suspect root traces $\sim 7 \%$ & III \\
\hline
\end{tabular}


Table 4. Continued.

\begin{tabular}{|c|c|c|c|c|c|c|c|c|}
\hline \multirow[b]{2}{*}{ Number } & \multirow[b]{2}{*}{ Section } & \multirow[b]{2}{*}{ Bedding } & \multicolumn{2}{|c|}{ Mud chips } & \multicolumn{2}{|c|}{ Bioturbation } & \multirow[b]{2}{*}{ Notes } & \multirow{2}{*}{$\begin{array}{l}\text { Assigned } \\
\text { Group }\end{array}$} \\
\hline & & & Size & Density & Burrow size & $\begin{array}{c}\text { Intensity } \\
\text { (I.I.) }\end{array}$ & & \\
\hline \multicolumn{9}{|c|}{ Thin Sections } \\
\hline JL117-1 & & throughout, intact & $<1 \mathrm{~mm}$ to $1 \sim 5 \mathrm{~mm}$ & $\begin{array}{l}40 \% \text { (only } \\
\text { at base) }\end{array}$ & - & 1 & $\begin{array}{l}\text { mud chips only at base, } \\
\text { incorporated from lower } \\
\text { layer, all flat-lying }\end{array}$ & I \\
\hline JL161-1 & & throughout, intact & - & - & - & 1 & drapes of oxides & $\mathrm{I}$ \\
\hline JL161-2 & & - & $<1 \mathrm{~mm}$ & $<5 \%$ & - & 1 & $\begin{array}{l}\text { some mud chips are } \\
\text { aligned }\end{array}$ & I \\
\hline JL161-4 & & throughout, intact & $<1 \mathrm{~mm}$ to $>5 \mathrm{~mm}$ & $<5 \%$ & $1 \sim 5 \mathrm{~mm}$ & 2 & & $\mathrm{I}$ \\
\hline \multirow{4}{*}{ JL161-7 } & Top & at base, intact & - & - & - & 1 & Sandstone & I \\
\hline & Middle & throughout, intact & - & - & $1 \sim 5 \mathrm{~mm}$ & 2 & & I \\
\hline & & & & & & & Sandstone, mud chips & \\
\hline & Bottom & - & $<1 \mathrm{~mm}$ & $\sim 5 \%$ & - & 1 & $\begin{array}{l}\text { only at base, } \\
\text { incorporated from below }\end{array}$ & $\mathrm{I}$ \\
\hline B.S.7.6 & & - & $<1 \mathrm{~mm}$ to $1 \sim 5 \mathrm{~mm}$ & $5 \%$ & - & 5 & $\begin{array}{l}\text { sandy } \\
\text { sandy, higher framework }\end{array}$ & III \\
\hline B.S.7.11 & & - & $<1 \mathrm{~mm}$ to $1 \sim 5 \mathrm{~mm}$ & $5 \%$ & - & 5 & $\begin{array}{l}\text { grain content compared } \\
\text { to all other thin sections }\end{array}$ & III \\
\hline \multicolumn{9}{|c|}{ Hand Samples } \\
\hline II 109-1 & Top left & throughout, partial & $<1 \mathrm{~mm}$ & medium & $<=1 \mathrm{~mm}$ & $3 \sim 4$ & & III \\
\hline & Remainder & throughout, intact & - & - & - & $1 \sim 2$ & & I \\
\hline JL109-2 & & at base, partial & - & - & $\begin{array}{c}<=1 \mathrm{~mm} \text { to } \\
1 \sim 5 \mathrm{~mm}\end{array}$ & $4 \sim 5$ & & III \\
\hline
\end{tabular}


Table 4. Continued.

\begin{tabular}{|c|c|c|c|c|c|c|c|c|}
\hline \multirow[b]{2}{*}{ Number } & \multirow[b]{2}{*}{ Section } & \multirow[b]{2}{*}{ Bedding } & \multicolumn{2}{|c|}{ Mud chips } & \multicolumn{2}{|c|}{ Bioturbation } & \multirow[b]{2}{*}{ Notes } & \multirow{2}{*}{$\begin{array}{c}\text { Assigned } \\
\text { Group }\end{array}$} \\
\hline & & & Size & Density & Burrow size & $\begin{array}{c}\text { Intensity } \\
\text { (I.I.) }\end{array}$ & & \\
\hline \multicolumn{9}{|c|}{ Hand Samples } \\
\hline JL109-4 & & throughout, partial & - & - & $<=1 \mathrm{~mm}$ & 4 & $\begin{array}{l}\text { bedding more broken up } \\
\text { than partially-preserved } \\
\text { beddings in other } \\
\text { samples, almost appear } \\
\text { contorted }\end{array}$ & III \\
\hline \multirow{2}{*}{ JL109-7 } & Lower left & throughout, intact & - & - & - & 1 & & I \\
\hline & Remainder & - & $<1 \mathrm{~mm}$ & medium & $<=1 \mathrm{~mm}$ & 5 & & III \\
\hline JL109-9 & & throughout, intact & - & - & $<=1 \mathrm{~mm}$ & 1 & may have sparsed roots? & $\mathrm{I} / \mathrm{II}$ \\
\hline \multirow[t]{2}{*}{ JL109-17 } & Upper half & throughout, intact & $<1 \mathrm{~mm}$ & low & $\begin{array}{c}<=1 \mathrm{~mm} \text { to } \\
1 \sim 5 \mathrm{~mm}\end{array}$ & $2 \sim 3$ & may have some roots? & II \\
\hline & Lower half & throughout, intact & - & - & - & 1 & & I \\
\hline JL110-4 & & $\begin{array}{l}\text { fining-up cycles, } \\
\text { throughout, intact }\end{array}$ & $<1 \mathrm{~mm}$ to $>5 \mathrm{~mm}$ & $<5 \%$ & - & 1 & $\begin{array}{l}\text { mud chips are flat-lying } \\
\text { and only present at the } \\
\text { base of each fining up } \\
\text { cycles, likely } \\
\text { incorporated from below }\end{array}$ & I \\
\hline
\end{tabular}


Table 5. Mean concentrations of major elements (quantified as oxides) in whole-rock samples (including both hand samples and thin sections) obtained in the first round of XRF analyses, and Mann-Whitney U Test results between greenish-gray and reddish-gray samples (statistically significant $p$ values are marked with *). Data for JL109-16R were obtained from the reddish-gray part of JL10916. All values reported in wt.\%. Standard errors are presented in parentheses. Sample numbers are color-coded with sample colors.

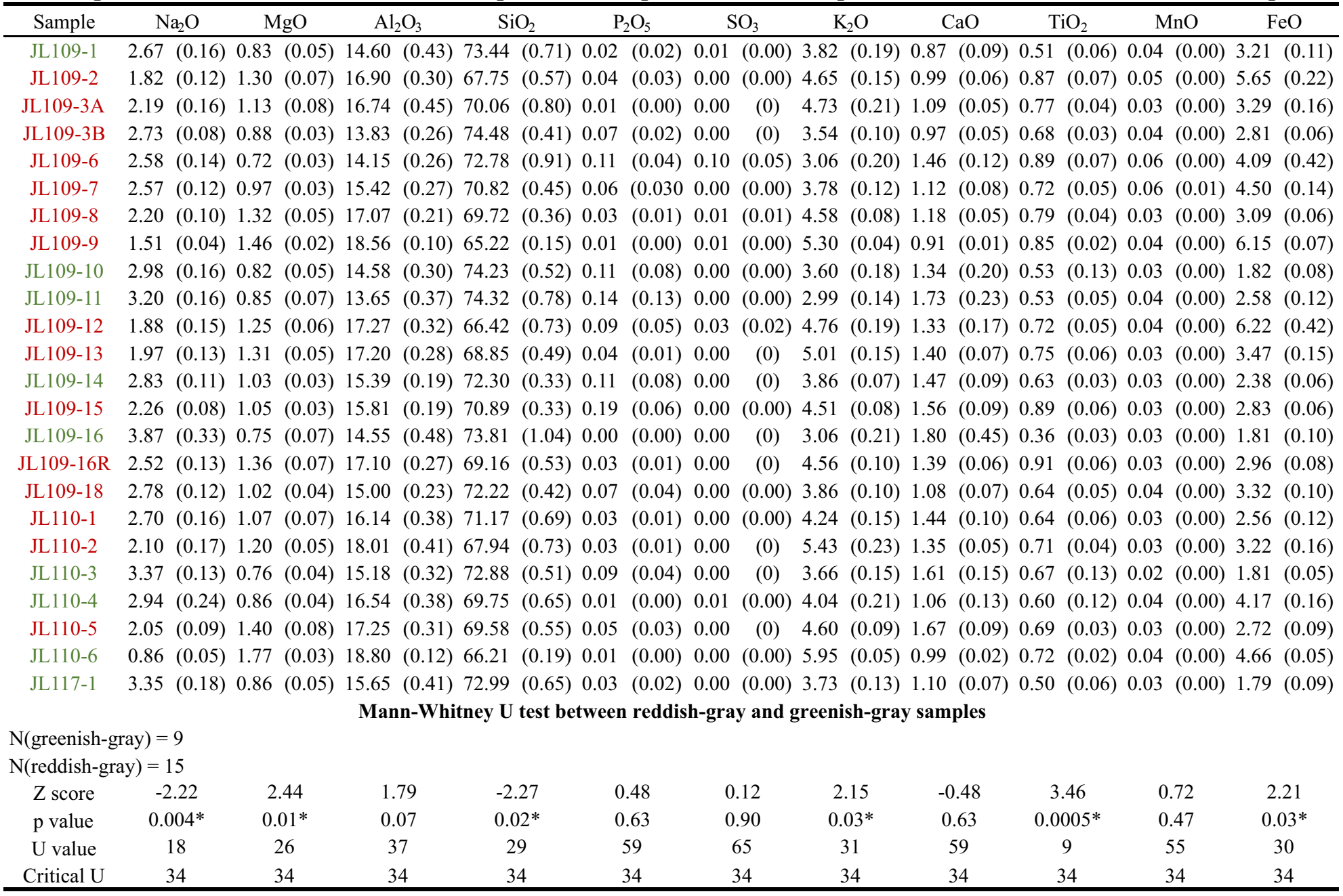


Table 6. Mean concentrations of major elements (quantified as oxides) in whole-rock samples (thin sections only) obtained in the second round of XRF analyses, and Mann-Whitney U Test results between greenish-gray and reddish-gray samples (statistically significant $\mathrm{p}$ values are marked with *). $(\mathrm{C})$ and $(\mathrm{F})$ in sample names indicate data obtained from the relatively coarse and fine parts, respectively, of the thin section. All values reported in wt.\%. Standard errors are presented in parentheses. Sample numbers are colorcoded with sample colors.

\begin{tabular}{|c|c|c|c|c|c|c|c|c|c|c|c|}
\hline Sample & $\mathrm{Na}_{2} \mathrm{O}$ & $\mathrm{MgO}$ & $\mathrm{Al}_{2} \mathrm{O}_{3}$ & $\mathrm{SiO}_{2}$ & $\mathrm{P}_{2} \mathrm{O}_{5}$ & $\mathrm{SO}_{3}$ & $\mathrm{~K}_{2} \mathrm{O}$ & $\mathrm{CaO}$ & $\mathrm{TiO}_{2}$ & $\mathrm{MnO}$ & $\mathrm{FeO}$ \\
\hline JL10 & $61(0.02)$ & $83(0.01)$ & $.46(0.05)$ & $29(0$. & $2(0.0$ & $0(0)$ & $0(0.02)$ & $2(0.01)$ & $\sigma 0$ & $03(0.00)$ & $(0$ \\
\hline & 3) & 1) & 7) & .54( & 1) & 00 & 12( & 99 & 2) & 0) & 05 \\
\hline JL10 & 3.13 & $0.89(0.02)$ & .06 & 73.61 & 9 & 01 & 49 ( & 28 & 52 & 0) & 3) \\
\hline JL109-11 & $2.94(0.04)$ & $1.07(0.02)$ & 14.28( & $73.71(0.19)$ & $0.02(0.00)$ & $0.00(0$ & $3.25(0.04)$ & $1.26(0.02)$ & 0.53 & $0.04(0.00)$ & $(0.05)$ \\
\hline JL109-13 (C) & 2.37 & $1.14(0.03)$ & 15.86 & 71.83 & $0.09(0$ & 0.00 & 4.33 & 1.23 & 0.55 & $0.03(0.00)$ & 2.60 \\
\hline JL109 & 2.50 & $1.08(0.03)$ & 5.06 & 73.03 & 0.04 & 0.00 & 3.93 & 1. & 0.5 & 0.03 & 2.5 \\
\hline JL109. & 2.86 & 1.08 & 5.81 & 71.54 & 0.12 & 0.00 & 3.98 & 1.38 & 0.66 & 0.03 & 3) \\
\hline JL10 & 2.84 & 11( & 5.88 & 71.61 & 0.07 & 0.00 & 3.98 & 1.45 & 0.64 & 0.0 & 2. \\
\hline JL10 & 2.37 & 1.03 & 16.25 & $70.31(0.18)$ & $0.19(0$ & 0.00 & $4.61(0.04)$ & $1.53(0.04)$ & 0.79 & 0.03 & 2.91 \\
\hline JL109-16 & $3.63(0.06)$ & $0.87(0.02)$ & 1) & $73.46(0.20)$ & $0.10(0.02)$ & $0.00(0$ & $(0.05)$ & 0.49 & $1.60(0.06)$ & $0.03(0.00)$ & $0.04)$ \\
\hline JL109-18 & $3.03(0.04)$ & $1.06(0.02)$ & $14.78(0.08)$ & $72.41(0.15)$ & $0.06(0.01)$ & $0.00(0.00)$ & $3.73(0.04)$ & $1.12(0.02)$ & $0.61(0.02)$ & $0.04(0.00)$ & $3.20(0.03)$ \\
\hline JL1 & 2.53 & 1.12 & 16.1 & 70.84 & $0.07(0$ & 0.00 & 4.44 & 1.48 & 0.63 & 0.03 & 2.7 \\
\hline & & 2) & 6.8 & 69.8 & 0.0 & & 4.5 & & & 0.0 & 2.7 \\
\hline JL1 & $0.86(0.05)$ & $1.77(0.03)$ & $18.80(0.12)$ & $66.21(0.19)$ & $0.01(0.00)$ & $0.00(0.00)$ & $5.95(0.05)$ & $0.99(0.02)$ & $0.72(0.02)$ & $0.04(0.00)$ & $4.66(0.05)$ \\
\hline JL117-1 & $3.24(0.06)$ & $0.83(0.02)$ & $15.29(0.12)$ & $73.16(0.21)$ & $0.15(0.04)$ & $0.00(0.00)$ & $3.74(0.05)$ & $1.29(0.06)$ & $0.54(0.02)$ & $0.03(0.00)$ & $1.75(0.04)$ \\
\hline
\end{tabular}

$\mathrm{N}($ greenish-gray $)=6$

$\mathrm{N}($ reddish-gray $)=9$

\begin{tabular}{|c|c|c|c|c|c|c|c|c|c|c|c|}
\hline Z score & -1.24 & 0.18 & 0.29 & -0.18 & -0.06 & -1.35 & 0.77 & 0.18 & -0.53 & -1.71 & 1.00 \\
\hline $\mathrm{p}$ value & 0.21 & 0.86 & 0.77 & 0.86 & 0.95 & 0.17 & 0.44 & 0.86 & 0.60 & 0.09 & 0.32 \\
\hline $\mathrm{U}$ value & 16 & 25 & 24 & 25 & 26 & 15 & 20 & 25 & 22 & 12 & 18 \\
\hline Critical U & 10 & 10 & 10 & 10 & 10 & 10 & 10 & 10 & 10 & 10 & 10 \\
\hline
\end{tabular}


Table 7. Mean concentrations of major elements (quantified as oxides) in clay fractions of 23 samples (marked with ${ }^{\mathrm{b}}$ in Table 1 and 2 ), obtained in the third round of XRF analyses, and Mann-Whitney U Test results between greenish-gray and reddish-gray samples (statistically significant $p$ values are marked with *). All values reported in wt.\%. Standard errors are presented in parentheses. Sample numbers are color-coded with sample colors.

\begin{tabular}{|c|c|c|c|c|c|c|c|c|c|c|c|c|c|c|c|c|c|c|}
\hline Sample & & $\mathrm{Na}_{2} \mathrm{O}$ & & $\mathrm{MgO}$ & & $\mathrm{l}_{2} \mathrm{O}_{3}$ & & $\mathrm{iO}_{2}$ & & $\mathrm{P}_{2} \mathrm{O}_{5}$ & & $\mathrm{O}_{3}$ & & $\mathrm{~K}_{2} \mathrm{O}$ & $\mathrm{CaO}$ & $\mathrm{TiO}_{2}$ & $\mathrm{MnO}$ & $\mathrm{FeO}$ \\
\hline JL109-1 & 1.97 & $(0.03)$ & 1.40 & $(0.01)$ & 18.73 & $(0.03)$ & 67.83 & $(0.06)$ & 0.00 & $(0.00)$ & 0.00 & $(0.00)$ & 5.51 & $(0.01)$ & $1.03(0.01)$ & $0.48(0.00)$ & $0.04(0.00)$ & $3.04(0.01)$ \\
\hline JL109-2 & 1.55 & $(0.03)$ & 1.65 & $(0.02)$ & 19.37 & $(0.04)$ & 66.10 & $(0.05)$ & 0.01 & $(0.00)$ & 0.00 & (0) & 5.66 & $(0.01)$ & $1.12(0.02)$ & $0.62(0.00)$ & 0.04 & $3.89(0.03)$ \\
\hline JL109-3B & 2.11 & $(0.03)$ & 1.17 & $(0.01)$ & 16.06 & $(0.04)$ & 71.18 & $(0.06)$ & 0.02 & $(0.00)$ & 0.00 & (0) & 4.15 & $(0.01)$ & $0.96(0.01)$ & $0.72(0.01)$ & $0.04(0.00)$ & $3.61(0.01)$ \\
\hline JL109-4 & 1.45 & $(0.04)$ & 1.55 & $(0.01)$ & 20.27 & $(0.03)$ & 65.58 & $(0.05)$ & 0.01 & $(0.00)$ & 0.00 & (0) & 5.96 & $(0.01)$ & $1.50(0.02)$ & $0.53(0.01)$ & $0.03(0.00)$ & $3.13(0.03)$ \\
\hline JL109-5 & 1.61 & $(0.04)$ & 1.37 & $(0.01)$ & 18.97 & $(0.04)$ & 67.18 & $(0.06)$ & 0.01 & $(0.00)$ & 0.00 & (0) & 5.53 & $(0.01)$ & $0.92(0.01)$ & $0.67(0.01)$ & $0.05(0.00)$ & $3.71(0.01)$ \\
\hline JL109-7 & 1.76 & $(0.03)$ & 1.46 & $(0.01)$ & 19.12 & $(0.03)$ & 67.80 & $(0.06)$ & 0.00 & $(0.00)$ & 0.00 & (0) & 5.23 & $(0.01)$ & $1.34(0.01)$ & $0.40(0.00)$ & $0.03(0.00)$ & $2.87(0.02)$ \\
\hline JL109-8 & 1.48 & $(0.03)$ & 1.60 & $(0.01)$ & 20.04 & $(0.04)$ & 64.79 & $(0.06)$ & 0.00 & $(0.00)$ & 0.00 & (0) & 5.72 & $(0.01)$ & $1.03(0.01)$ & $0.71 \quad(0.00)$ & $0.04(0.00)$ & $4.62(0.02)$ \\
\hline JL109-9 & 1.25 & $(0.05)$ & 1.62 & $(0.01)$ & 20.65 & $(0.04)$ & 64.20 & $(0.06)$ & 0.01 & $(0.00)$ & 0.01 & $(0.01)$ & 6.28 & $(0.02)$ & $1.31(0.03)$ & $0.72(0.01)$ & $0.03(0.00)$ & $3.94(0.04)$ \\
\hline JL10 & 1.81 & $(0.02)$ & 1.46 & $(0.01)$ & 18.95 & $(0.03)$ & 67.27 & $(0.05)$ & 0.01 & $(0.00)$ & 0.00 & (0) & 5.16 & $(0.01)$ & $0.92(0.01)$ & $0.47(0.01)$ & $0.05(0.00)$ & $3.93(0.01)$ \\
\hline JL109-11 & 1.93 & $(0.04)$ & 1.70 & $(0.02)$ & 17.80 & $(0.05)$ & 67.87 & (0.09) & 0.03 & $(0.02)$ & 0.00 & $(0.00)$ & 4.52 & $(0.01)$ & $2.20(0.03)$ & $0.57(0.01)$ & $0.05(0.00)$ & $3.35(0.03)$ \\
\hline JL10 & 1.25 & $(0.04)$ & 1.61 & $(0.01)$ & 19.84 & (0.06) & 64.39 & (0.09) & 0.02 & $(0.01)$ & 0.00 & $(0.00)$ & 6.20 & $(0.02)$ & 1.29 & $0.74(0.01)$ & $0.03(0.00)$ & $4.64(0.04)$ \\
\hline JL10 & 2.51 & $(0.03)$ & 1.42 & $(0.01)$ & 17.40 & $(0.03)$ & 68.60 & $(0.05)$ & 0.01 & $(0.00)$ & 0.00 & (0) & 4.28 & $(0.01)$ & $1.60(0.02)$ & $0.46(0.00)$ & $0.05(0.00)$ & $3.68(0.01)$ \\
\hline JL1C & 1.88 & $(0.04)$ & 1.50 & $(0.02)$ & 18.56 & $(0.06)$ & 66.53 & $(0.09)$ & 0.03 & $(0.01)$ & 0.00 & (0) & 5.22 & $(0.02)$ & 1.08 & $0.70(0.01)$ & 0.05 & $4.47(0.03)$ \\
\hline JL1C & 1.93 & $(0.03)$ & 1.61 & $(0.01)$ & 18.54 & $(0.04)$ & 66.18 & $.06)$ & 0.02 & $(0.00)$ & 0.00 & $(0.00)$ & 5.07 & $(0.02)$ & 1.01 & 0.70 & $0.05(0.00)$ & 4.92 \\
\hline $\mathrm{Jl}$ & 1.59 & ) & 1.53 & $(0$ & 18.82 & ) & .34 & & 0.04 & 2) & 0.00 & (0) & 5.48 & 2) & 1.22 & $0.61 \quad(0.01)$ & 0.05 & 4.35 \\
\hline JL110-2 & 1.39 & $(0.03)$ & 1.51 & $(0.01)$ & 20.52 & $(0.05)$ & 63.19 & $(0.06)$ & 0.01 & $(0.00)$ & 0.00 & (0) & 6.47 & $(0.02)$ & $1.11(0.01)$ & $0.70(0.01)$ & $0.04(0.00)$ & $5.10(0.02)$ \\
\hline JL110-3 & 1.76 & $(0.04)$ & 1.41 & $(0.01)$ & 19.72 & $(0.06)$ & 65.71 & $(0.09)$ & 0.01 & $(0.01)$ & 0.00 & (0) & 5.69 & $(0.02)$ & $0.93(0.01)$ & $0.46(0.01)$ & $0.05(0.00)$ & $4.28(0.02)$ \\
\hline JL110-4 & 2.26 & $(0.04)$ & 1.25 & $(0.01)$ & 19.46 & $(0.05)$ & 65.57 & $(0.07)$ & 0.00 & $(0.00)$ & 0.00 & (0) & 5.01 & $(0.02)$ & $1.07(0.01)$ & $0.46(0.01)$ & $0.05(0.00)$ & $4.90(0.03)$ \\
\hline JL117-1 & 1.93 & $(0.03)$ & 1.36 & $(0.01)$ & 19.45 & $(0.05)$ & 67.14 & $(0.08)$ & 0.01 & $(0.00)$ & 0.00 & (0) & 5.23 & $(0.02)$ & $0.97(0.01)$ & $0.58(0.01)$ & $0.04(0.00)$ & $3.32(0.02)$ \\
\hline JL161-1 & 2.36 & $(0.03)$ & 1.10 & $(0.01)$ & 16.46 & $(0.05)$ & 70.02 & $(0.07)$ & 0.02 & $(0.00)$ & 0.00 & (0) & 4.18 & $(0.01)$ & $2.05(0.02)$ & $0.50(0.00)$ & $0.06(0.00)$ & $3.28(0.01)$ \\
\hline JL161-2 & 2.07 & $(0.04)$ & 1.35 & $(0.01)$ & 19.10 & $(0.04)$ & 66.86 & $(0.07)$ & 0.02 & $(0.01)$ & 0.01 & $(0.00)$ & 5.29 & $(0.01)$ & $1.63(0.05)$ & $0.43(0.00)$ & $0.04(0.00)$ & $3.20(0.02)$ \\
\hline JL1 & 1.82 & $(0.03)$ & 1.36 & $(0.02)$ & 19.43 & $(0.02)$ & 66.39 & $(0.03)$ & 0.00 & $(0.00)$ & 0.00 & (0) & 5.27 & $(0.01)$ & $1.63(0.00)$ & $0.82(0.00)$ & $0.04(0.00)$ & $3.27(0.01)$ \\
\hline JL161-7 & 1.1 & $(0.03)$ & 1.8 & $(0.02)$ & 20.38 & $(0.02)$ & 64.34 & $(0.03)$ & 0.02 & $(0.00)$ & 0.00 & $(0.00)$ & 6.39 & $(0.01)$ & $1.29(0.01)$ & $0.64(0.00)$ & $0.07(0.00)$ & $3.87(0.01)$ \\
\hline \multicolumn{19}{|c|}{ Mann-Whitney $U$ test between reddish-gray and greenish-gray samples } \\
\hline \multicolumn{19}{|c|}{$\mathrm{N}($ greenish-gray $)=11$} \\
\hline \multicolumn{19}{|c|}{$\mathrm{N}($ reddish-gray $)=12$} \\
\hline Z score & & 2.40 & & 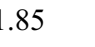 & & .11 & & 1.51 & & 8 & & & & 1 & -0.80 & 2.37 & -2.00 & 1.63 \\
\hline & & $.02 *$ & & 0.07 & & .44 & & .13 & & 0.56 & & .00 & & .12 & 0.42 & $0.02 *$ & $0.05^{*}$ & 0.10 \\
\hline $\mathrm{U}$ value & & 26.5 & & 36 & & 53 & & 41 & & 56 & & 2.5 & & 40 & 52.5 & 27 & 33 & 39 \\
\hline Critical U & & 33 & & 33 & & 33 & & 33 & & 33 & & 33 & & 33 & 33 & 33 & 33 & 33 \\
\hline
\end{tabular}


Table 8. Mineralogy of the clay fractions of samples as derived using XRD facility at Southern Methodist University, Dallas, Texas (7-14, January 2016). See Methods for details.

\begin{tabular}{ll}
\hline Peaks present & \multicolumn{1}{c}{ Identification } \\
\hline $14 \AA$ & Chlorite (primary) \\
$10 \AA$ & Illite (primary) \\
$7 \AA$ & Chlorite (secondary) \\
$5 \AA$ & Illite (secondary) \\
$4.71 \AA$ & Chlorite \\
$4.26 \AA$ & Quartz (secondary) \\
$4.5 \AA$ & Yet to be identified \\
$3.53 \AA$ & Chlorite \\
$3.345 \AA$ & Quartz (primary) \\
$3.195 \AA$ & Plagioclase \\
\hline
\end{tabular}


Table 9. Results of Mössbauer spectroscopy undertaken in the Mt. Holyoke facility of Dr. Darby Dyar. All values reported as percentage of total iron concentration. See Methods for details.

\begin{tabular}{ccccccc}
\hline $\begin{array}{c}\text { Sample } \\
\text { Number }\end{array}$ & Color & Total Fe $\%$ & $\mathrm{Total} \mathrm{Fe}^{3+} \%$ & $\begin{array}{c}\mathrm{Fe}^{3+} \text { in octahedral } \\
\text { site } \%\end{array}$ & $\begin{array}{c}\mathrm{Fe}^{+3} \text { as fine-grained } \\
\text { hematite } \%\end{array}$ & $\begin{array}{c}\mathrm{Hematite}^{2+} \\
\text { concentration wt.\% }\end{array}$ \\
\hline JL109-3B & reddish-gray (5YR 3/1) & 31.08 & 68.93 & 40.36 & 28.57 & 1.03 \\
JL109-10 & greenish-gray (5Y 4/1) & 44.31 & 55.69 & 55.69 & 0.00 & 0.00 \\
JL109-16 & greenish-gray (5Y 4/1) & 47.55 & 52.45 & 45.33 & 7.12 & 0.26 \\
JL109-18 & reddish-gray (5YR 3/1) & 41.60 & 58.40 & 42.49 & 3.91 & 0.78 \\
B.S.7.6 & reddish-gray (5YR 4/1) & 38.36 & 61.65 & 36.10 & 25.55 & 0.00 \\
B.S.7.11 & greenish-gray (10Y 6/2) & 59.21 & 40.80 & 40.80 & 0.00 \\
\hline
\end{tabular}


Table 10. Elemental data obtained by EDAX on clay minerals coated by hematite at the Electron Microscope Laboratory, School of Earth and Climate Science, the University of Maine-Orono, 16 and 23, February 2016. Identification of the two clay minerals are based on the concentration of K. See Figure 14 for locations on grains from which data were obtained. All values reported in wt.\%.

\begin{tabular}{lllllllllll}
\hline Sample & $\begin{array}{l}\text { Data } \\
\text { acquisition } \\
\text { location }\end{array}$ & $\mathrm{Na}_{2} \mathrm{O}$ & $\mathrm{MgO}$ & $\mathrm{Al}_{2} \mathrm{O}_{3}$ & $\mathrm{SiO}_{2}$ & $\mathrm{~K}_{2} \mathrm{O}$ & $\mathrm{CaO}$ & $\mathrm{TiO}_{2}$ & $\mathrm{FeO}$ Identification \\
\hline B.S.7.6 & 2 (Fig. 16A) & 0.00 & 4.35 & 19.43 & 35.05 & 1.82 & 0.42 & 0.26 & 39.21 Illite \\
JL109-18 & 3 (Fig. 16B) & 0.78 & 7.82 & 20.83 & 35.09 & 0.78 & 0.65 & 0.36 & 33.70 Chlorite \\
\hline
\end{tabular}


Table 11. Examples of elemental data obtained by EDAX at the University of Maine's facility on oxides and Ti-silicate. All values reported in wt.\%. The magnetite grain is compositionally similar to ilmenite and may have been misidentified, but the presence of magnetite is confirmed by paleomagnetic data (Dr. J. Geissman, personal communication).

\begin{tabular}{|c|c|c|c|c|c|c|c|c|c|}
\hline Sample & $\mathrm{Na}_{2} \mathrm{O}$ & $\mathrm{MgO}$ & $\mathrm{Al}_{2} \mathrm{O}_{3}$ & $\mathrm{SiO}_{2}$ & $\mathrm{~K}_{2} \mathrm{O}$ & $\mathrm{CaO}$ & $\mathrm{TiO}_{2}$ & $\mathrm{FeO}$ & Identification \\
\hline JL109-3B & 0.00 & 0.14 & 1.63 & 0.81 & 0.18 & 0.25 & 0.58 & 96.42 & Crystalline Hematite \\
\hline JL109-3B & 0.82 & 0.67 & 4.48 & 7.02 & 0.85 & 0.72 & 75.61 & 9.82 & Rutile \\
\hline JL109-18 & - & 0.30 & 11.37 & 42.17 & 0.62 & 24.85 & 13.27 & 7.42 & Titanite \\
\hline JL109-18 & - & 0.07 & 4.09 & 1.16 & 0.32 & 0.32 & 20.80 & 73.24 & Ilmenite \\
\hline B.S.7.6 & 0.95 & 0.28 & 1.97 & 5.07 & 0.52 & 0.48 & 23.65 & 69.09 & Magnetite \\
\hline
\end{tabular}


Table 12. Values of weathering indices if all siltstone samples are considered subaerially exposed. Weathering indices calculated include base loss and Chemical Index of Alteration minus Potassium (CIA-K). Samples are arranged in the order of increasing CIA-K values from the top to bottom.

\begin{tabular}{|c|c|c|c|c|}
\hline \multirow{2}{*}{ Sample \# } & \multirow{2}{*}{ CIA-K } & \multicolumn{2}{|c|}{ Base Loss } & \multirow{2}{*}{$\begin{array}{c}\text { Sedimentary } \\
\text { Structure Group }\end{array}$} \\
\hline & & $\mathrm{Ca} / \mathrm{Ti}$ & $\mathrm{Na} / \mathrm{Ti}$ & \\
\hline JL161-1 & 68.38 & 4.13 & 4.75 & $\bar{I}$ \\
\hline JL109-16 & 71.16 & 3.47 & 5.43 & III \\
\hline JL109-11 & 71.25 & 3.87 & 3.40 & II \\
\hline JL161-2 & 75.00 & 3.76 & 4.76 & I \\
\hline JL109-3B & 75.50 & 1.33 & 2.92 & I \\
\hline JL109-7 & 78.19 & 3.36 & 4.42 & $\mathrm{I}+\mathrm{III}$ \\
\hline JL109-1 & 78.57 & 2.15 & 4.14 & I + III \\
\hline JL109-17 & 78.58 & 1.54 & 2.68 & II \\
\hline JL109-18 & 78.76 & 1.43 & 2.74 & I \\
\hline JL110-1 & 79.54 & 2.01 & 2.63 & III \\
\hline JL117-1 & 79.79 & 1.66 & 3.31 & I \\
\hline JL109-4 & 79.85 & 2.81 & 2.71 & III \\
\hline JL109-10 & 80.31 & 1.96 & 3.85 & III \\
\hline JL109-2 & 80.88 & 1.80 & 2.48 & III \\
\hline JL110-3 & 81.15 & 2.01 & 3.79 & I + III \\
\hline JL109-5 & 81.46 & 1.38 & 2.42 & - \\
\hline JL109-13 & 81.81 & 1.74 & 1.69 & III \\
\hline JL109-9 & 82.30 & 1.81 & 1.73 & I \\
\hline JL109-8 & 82.33 & 1.45 & 2.09 & I \\
\hline JL110-2 & 82.69 & 1.58 & 1.99 & III \\
\hline
\end{tabular}




\section{Appendix B.}

Total organic Content (TOC) values of several OLP and Bethulie samples.

\section{Method}

Five to ten mg of each powdered sample was weighed out into a beaker, and a drop of $10 \% \mathrm{HCl}$ was added to determine if there is a carbonate fraction. The beakers were rinsed with carbon-free water and placed into an ultrasonic bath for 4 to 5 minutes. Samples were filtered onto a cellulose-free pre-combusted $25 \mathrm{~mm}$ diameter filter, and then dried at $85^{\circ} \mathrm{C}$. A Mettler Balance was used to weigh out 2.000 to $4.000 \mathrm{mg}$ of powdered sample for TOC analysis with a Perkin Elmer 2400 Elemental Analyzer.

Powdered samples were weighed into tin capsules and were automatically introduced into a furnace combustion tube in a pure oxygen atmosphere. Temperatures produced from the reaction between the tin and oxygen were $\sim 1800^{\circ} \mathrm{C}$, ensuring complete combustion of the sample. Helium was used to carry combustion products of the sample through the analytical system. The combustion products were converted to $\mathrm{CO}_{2}, \mathrm{H}_{2} \mathrm{O}$, and $\mathrm{N}_{2}$ and quantified using a thermal conductivity detector for each as referenced against a standard (e.g., acetanilide $[\mathrm{CHNO}]$ or cystine $[\mathrm{CHNO}+\mathrm{S}]$ ).

\section{Results}

\begin{tabular}{lcccc}
\hline Sample & Lithology & Munsell color & Descriptive color & Mean TOC \% \\
\hline JL110-2 & siltstone & 7.5 YR 4/2 & brown & 0.50 \\
JL161-1 & siltstone & 10Y 5/1 & greenish gray & 0.37 \\
JL161-3 & sandstone & $5 Y 5 / 2$ & olive gray & 0.25 \\
JL161-4 & siltstone & 10Y 6/1 & greenish gray & 0.44 \\
JL161-5 & sandstone & 10R 4/1 & dark reddish gray & 0.40 \\
JL161-6 & sandstone & 10Y 5/1 & greenish gray & 0.25 \\
JL161-7 & siltstone & 10GY 5/1 & greenish gray & 0.26 \\
JL161-8 & sandstone & 10YR 6/1 & gray & 0.71 \\
\hline
\end{tabular}




\section{Appendix A.}

Photomicrographs of thin sections not shown in Figures 5, 6, and 7. Thin sections are in stratigraphic up orientation recorded in the field, except for JL109-14, JL109-15, and JL161-2. The stratigraphic up orientation of JL109-14 and JL109-15 thin sections are inferred from fining-up cycles within the samples. The stratigraphic up orientation of JL161-2 was not recorded in the field. (A) JL109-3A; (B) JL109-13; (C) JL109-14; (D) JL109-15; (E) JL110-3; (F) JL110-5; (G) JL110-6; (H) JL161-2; (I) JL161-4; and (J) JL61-7.
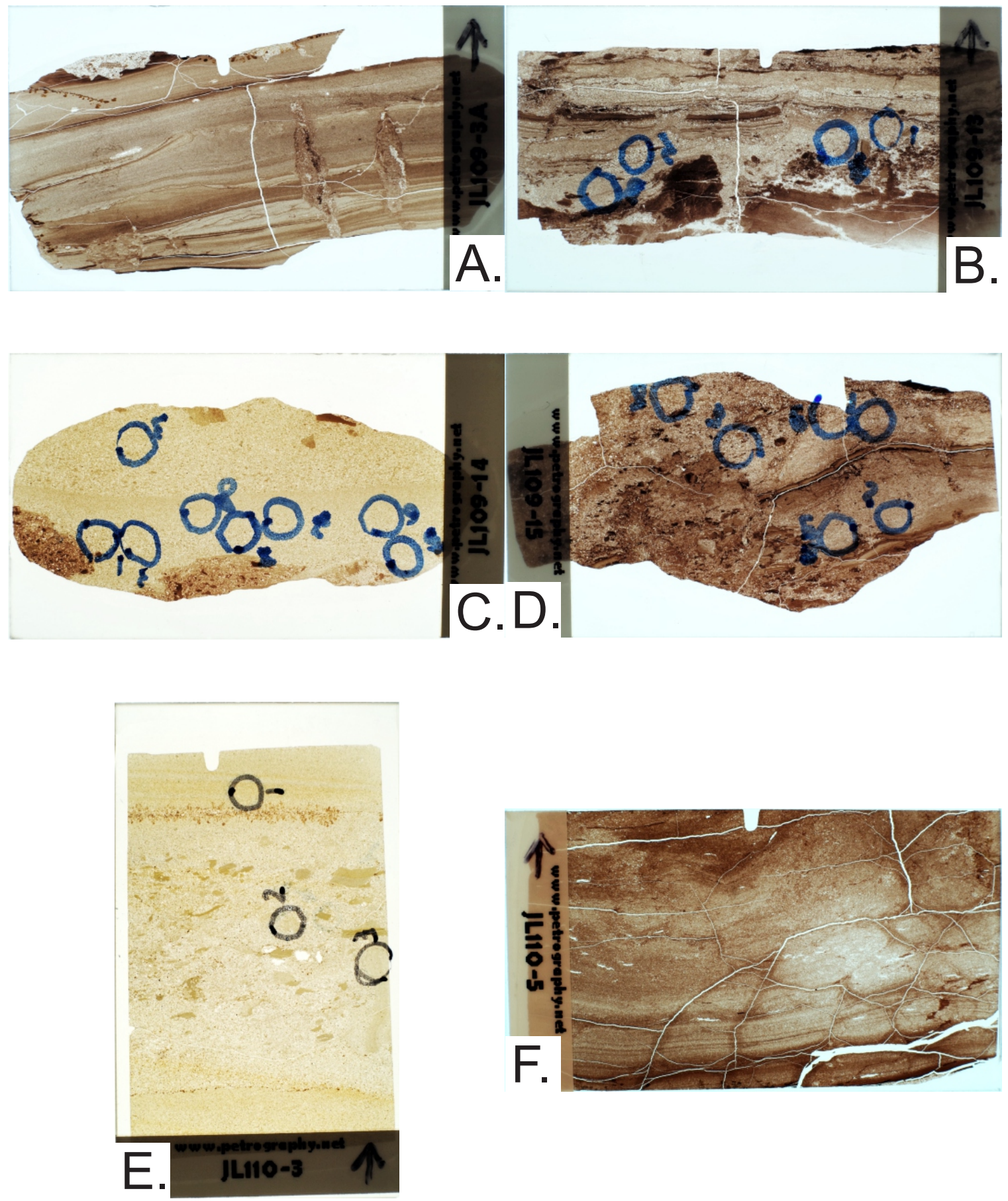
Appendix A. Continued.
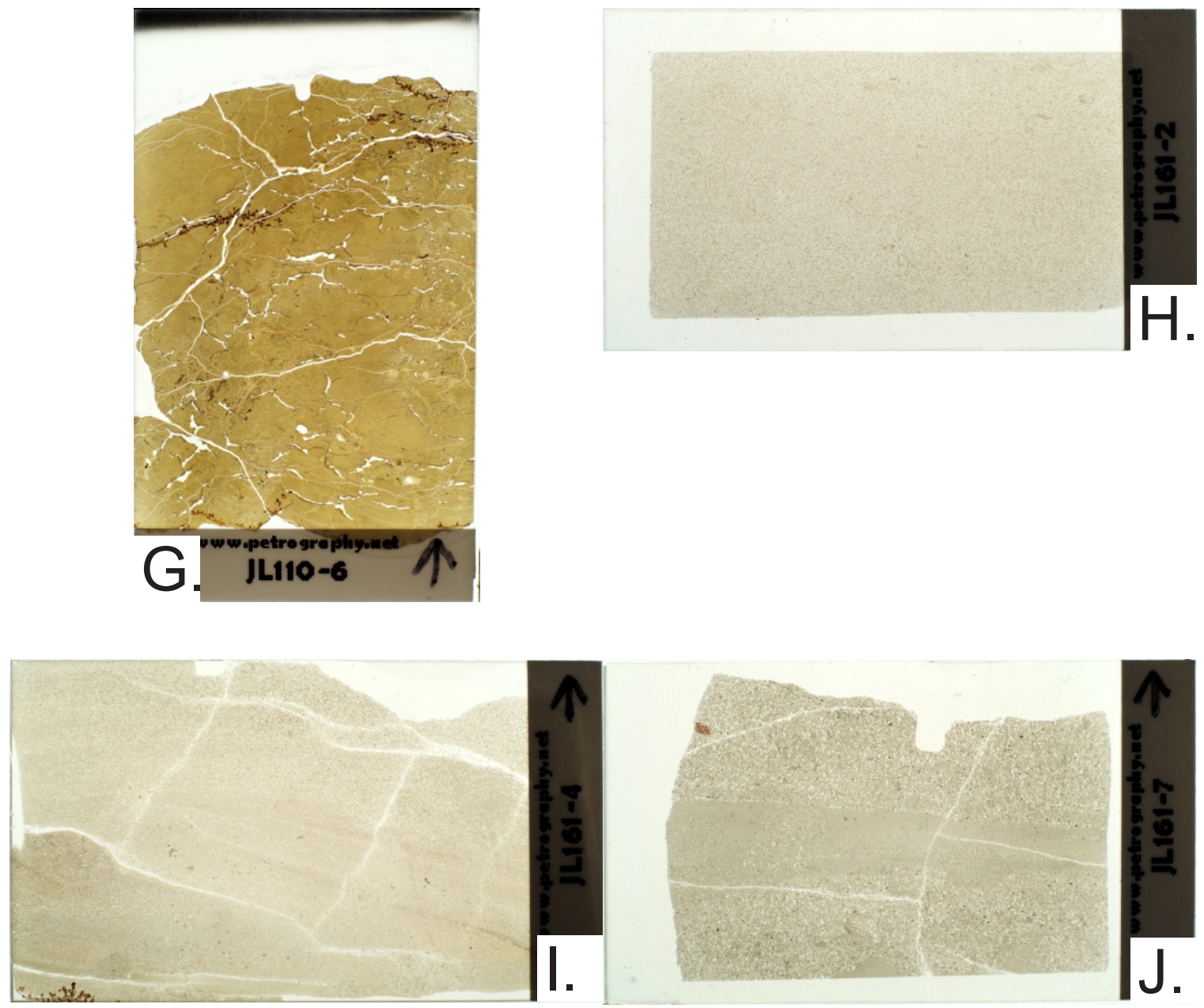


\section{Appendix B.}

Total organic Content (TOC) values of several OLP and Bethulie samples.

\section{Method}

Five to ten mg of each powdered sample was weighed out into a beaker, and a drop of $10 \% \mathrm{HCl}$ was added to determine if there is a carbonate fraction. The beakers were rinsed with carbon-free water and placed into an ultrasonic bath for 4 to 5 minutes. Samples were filtered onto a cellulose-free pre-combusted $25 \mathrm{~mm}$ diameter filter, and then dried at $85^{\circ} \mathrm{C}$. A Mettler Balance was used to weigh out 2.000 to $4.000 \mathrm{mg}$ of powdered sample for TOC analysis with a Perkin Elmer 2400 Elemental Analyzer.

Powdered samples were weighed into tin capsules and were automatically introduced into a furnace combustion tube in a pure oxygen atmosphere. Temperatures produced from the reaction between the tin and oxygen were $\sim 1800^{\circ} \mathrm{C}$, ensuring complete combustion of the sample. Helium was used to carry combustion products of the sample through the analytical system. The combustion products were converted to $\mathrm{CO}_{2}, \mathrm{H}_{2} \mathrm{O}$, and $\mathrm{N}_{2}$ and quantified using a thermal conductivity detector for each as referenced against a standard (e.g., acetanilide $[\mathrm{CHNO}]$ or cystine $[\mathrm{CHNO}+\mathrm{S}]$ ).

\section{Results}

\begin{tabular}{lcccc}
\hline Sample & Lithology & Munsell color & Descriptive color & Mean TOC \% \\
\hline JL110-2 & siltstone & 7.5 YR 4/2 & brown & 0.50 \\
JL161-1 & siltstone & 10Y 5/1 & greenish gray & 0.37 \\
JL161-3 & sandstone & $5 Y 5 / 2$ & olive gray & 0.25 \\
JL161-4 & siltstone & 10Y 6/1 & greenish gray & 0.44 \\
JL161-5 & sandstone & 10R 4/1 & dark reddish gray & 0.40 \\
JL161-6 & sandstone & 10Y 5/1 & greenish gray & 0.25 \\
JL161-7 & siltstone & 10GY 5/1 & greenish gray & 0.26 \\
JL161-8 & sandstone & 10YR 6/1 & gray & 0.71 \\
\hline
\end{tabular}




\section{Appendix B.}

Total organic Content (TOC) values of several OLP and Bethulie samples.

\section{Method}

Five to ten mg of each powdered sample was weighed out into a beaker, and a drop of $10 \% \mathrm{HCl}$ was added to determine if there is a carbonate fraction. The beakers were rinsed with carbon-free water and placed into an ultrasonic bath for 4 to 5 minutes. Samples were filtered onto a cellulose-free pre-combusted $25 \mathrm{~mm}$ diameter filter, and then dried at $85^{\circ} \mathrm{C}$. A Mettler Balance was used to weigh out 2.000 to $4.000 \mathrm{mg}$ of powdered sample for TOC analysis with a Perkin Elmer 2400 Elemental Analyzer.

Powdered samples were weighed into tin capsules and were automatically introduced into a furnace combustion tube in a pure oxygen atmosphere. Temperatures produced from the reaction between the tin and oxygen were $\sim 1800^{\circ} \mathrm{C}$, ensuring complete combustion of the sample. Helium was used to carry combustion products of the sample through the analytical system. The combustion products were converted to $\mathrm{CO}_{2}, \mathrm{H}_{2} \mathrm{O}$, and $\mathrm{N}_{2}$ and quantified using a thermal conductivity detector for each as referenced against a standard (e.g., acetanilide $[\mathrm{CHNO}]$ or cystine $[\mathrm{CHNO}+\mathrm{S}]$ ).

\section{Results}

\begin{tabular}{lcccc}
\hline Sample & Lithology & Munsell color & Descriptive color & Mean TOC \% \\
\hline JL110-2 & siltstone & 7.5 YR 4/2 & brown & 0.50 \\
JL161-1 & siltstone & 10Y 5/1 & greenish gray & 0.37 \\
JL161-3 & sandstone & $5 Y 5 / 2$ & olive gray & 0.25 \\
JL161-4 & siltstone & 10Y 6/1 & greenish gray & 0.44 \\
JL161-5 & sandstone & 10R 4/1 & dark reddish gray & 0.40 \\
JL161-6 & sandstone & 10Y 5/1 & greenish gray & 0.25 \\
JL161-7 & siltstone & 10GY 5/1 & greenish gray & 0.26 \\
JL161-8 & sandstone & 10YR 6/1 & gray & 0.71 \\
\hline
\end{tabular}

